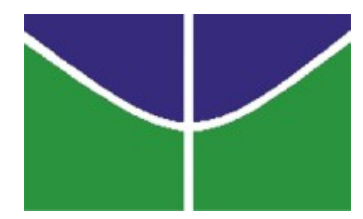

\author{
UNIVERSIDADE DE BRASÍLIA \\ INSTITUTO DE FÍSICA \\ PROGRAMA DE PÓS-GRADUAÇÃO DE MESTRADO \\ PROFISSIONAL EM ENSINO DE FÍSICA \\ MESTRADO NACIONAL PROFISSIONAL EM ENSINO DE FÍSICA \\ SOCIEDADE BRASILEIRA DE FÍSICA
}

FÍSICA DE PLASMA NO ENSINO MÉDIO

GUSTAVO MULIM VENCESLAU

BRASÍLIA - DF

2015 


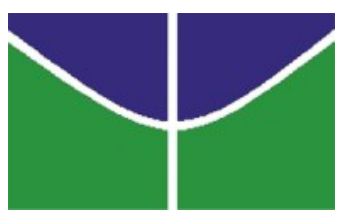

UNIVERSIDADE DE BRASÍLIA INSTITUTO DE FÍSICA

PROGRAMA DE PÓS-GRADUAÇÃO DE MESTRADO PROFISSIONAL EM ENSINO DE FÍSICA

MESTRADO NACIONAL PROFISSIONAL EM ENSINO DE FÍSICA SOCIEDADE BRASILEIRA DE FÍSICA

\title{
FÍSICA DE PLASMA NO ENSINO MÉDIO
}

\author{
GUSTAVO MULIM VENCESLAU
}

Dissertação realizada sob orientação da Prof. Dr. José Leonardo Ferreira a ser apresentada à banca examinadora como requisito parcial à obtenção do Título de Mestre em Ensino de Física - Área de Concentração "Física no Ensino Básico" pelo Programa de PósGraduação de Mestrado Profissional em Ensino de Física da Universidade de Brasília.

BRASÍLIA - DF 
FOLHA DE APROVAÇÃO

GUSTAVO MULIM VENCESLAU

\section{FíSICA DE PLASMA NO ENSINO MÉDIO}

Dissertação apresentada à banca examinadora como requisito parcial à obtenção do Título de Mestre em Ensino de Física - Área de Concentração "Física na Educação Básica“ pelo Programa de Pós-Graduação de Mestrado Profissional em Ensino de Física da Universidade de Brasília.

Aprovada em

BANCA EXAMINADORA

Prof. Dr. José Leonardo Ferreira

(Presidente)

Prof. Dr. Fábio Menezes de Souza Lima

(Membro interno vinculado ao programa - IF UnB)

Prof. Dra. Vanessa Carvalho de Andrade

(Membro interno vinculada ao programa - IF UnB)

Prof. Dr. Wytler Cordeiro dos Santos

(Membro interno vinculado ao programa - IF UnB)

Prof. Dr. Joao Paulo Martins de Castro Chaib

(Membro externo não vinculado ao programa - UCB) 


\section{Dedicatória}

Este trabalho é uma singela amostra da dedicação de uma família sob a Graça de Deus.

Dedico-o a Deus, pela Graça transformadora em nossas vidas.

Aos meus pais, Leleir e Izabel, pela paciência, pela persistência e pelo incansável amor aos seus filhos e netos e à vida.

À minha esposa Luciana, pelo resignado e amoroso suporte e compreensão em todas as horas.

Ao Artur e ao Guilherme por emprestar seus tempos de infância à realização de um sonho do pai e pela inspiração.

Aos meus irmãos Rafael, Bruno e Daniel companheiros fieis, sempre alertas para servir o melhor possível.

Às minhas irmãs Helena e Cristiane, grandes guerreiras. 


\section{Agradecimentos}

Ao Deus.

À Luciana, ao Artur e ao Guilherme.

Ao Leleir, à Izabel, ao Cesar, à Helena, à Cristiane (in memorian), ao Rafael, ao Bruno e ao Daniel.

Ao Rodrigo e à Izabel.

Ao Léo.

Ao Alexandre, ao Ernesto, ao Kaio e ao Mathias.

Ao Edilson e ao Alexandre.

Ao Delfim, ao Pedreira, à Eliana, ao Téo, à Cecília e ao Ramos.

Ao Fábio, ao Antônio Luciano, ao Antônio Cleves e à Deise.

À Maria de Fátima e à Anita.

Ao Caldas, ao Ademir, ao Portilho, ao Beaklini, ao Antony, à Vanessa, à Eliana, ao Ronni, ao Eduardo, ao Marciano, ao Amato, ao Sebastião, ao Nilo, ao Junio, ao Daniel, à Reva, ao Vijaendra, ao Acioli (in memorian), à Zilda, ao Logrado, ao Irineu, ao Otil.

Ao Sylvicley, ao Amilcar, ao Celso, ao Ricardo, ao Frank, ao Caio, ao André, ao Jojomar, à Érica, à Ana Paula, ao Luis, ao Marco Antônio, ao Ítalo, ao Leonardo, ao Washington, ao Pena, ao Witler, ao Angelo, ao Flávio, ao Pufal, ao Marco Aurélio, ao Sebastião, à Sandra,

Ao Noel, ao Zé, ao Marcelo, ao Braga, à Cláudia. 


\section{Agradecimentos Especiais}

Ao admirado Prof. Dr. José Leonardo Ferreira e sua equipe.

À Prof. Dra. Maria de Fátima da Silva Verdeaux.

À Direção do Colégio Dromos.

À Equipe do Laboratório de Plasmas da Universidade de Brasília.

À Equipe da Oficina Mecânica do Instituto de Física da Universidade de Brasília. Ao Mestrado Nacional Profissional em Ensino de Física.

À Sociedade Brasileira de Física. 
"A mente que se abre a uma nova ideia jamais volta ao seu tamanho original." Albert Einstein 


\section{Resumo}

Venceslau, Gustavo Mulim. Física de plasma no ensino médio. 2015. 97 f. Dissertação (Mestrado) Universidade de Brasília - Brasília/DF, 2015.

É pouco expressiva a quantidade de tópicos de física moderna estudados no ensino básico. A física de plasma tem a capacidade de concatenar abordagens teóricas e cotidianas da física moderna porém é praticamente inexistente material dirigido a professores e alunos do ensino básico. E menor ainda é o número de experiências relatadas de abordagem desse ramo da física nas escolas. Este trabalho apresenta um aparato experimental portável para uso em sala de aula, tubo de Crookes, e material didático teórico, publicado em forma de site, destinados à introdução de física de plasma no ensino fundamental e médio e à compreensão básica do funcionamento do experimento, podendo ser usado também para o ensino superior. O material didático foi desenvolvido tendo como foco a evolução histórica de conceitos, técnicas e tecnologias, que levaram à identificação e caracterização do quarto estado da matéria. Evitou-se o uso do desenvolvimento matemático como caminho para a construção dos conceitos, embora algum seja necessário. Os conceitos de carga e corrente elétricas, campos elétrico e magnético, temperatura e transição de fases são tomados como pré-requisitos necessários ao encadeamento das aulas como proposto. A aula experimental pode acontecer a qualquer tempo. Procurou-se afastar a necessidade de prérequisitos matemáticos, como o uso de equações diferenciais, para compreensão de conceitos modernos como comprimento de Debye e frequencia de plasma, fazendo o uso de analogias e dos conceitos indicados. Obteve-se um material conciso e com apelo instrucional capaz de capturar a atenção dos alunos para a relevância do estudo de física e para a presença da física de plasma no dia-a-dia, mostra-se desta forma que os conceitos das ciências estão perto deles e que estão em desenvolvimento, trazendo um sensação de proximidade entre a fronteira da ciência e a vida cotidiana, indicando condições para aprimoramentos conceituais futuros e instigando-os à busca por conhecimento.

Palavras-chaves: física de plasma, tubo de Crookes, descargas elétricas em gases, ensino básico, tecnologias, atualidade, evolução histórica. 


\begin{abstract}
Venceslau, Gustavo Mulim. Física de plasma no ensino médio. 2015. 97 f. Dissertação (Mestrado) Universidade de Brasília - Brasília/DF, 2015.

It is not very significant the amount of topics of modern physics studied in primary education. Plasma physics has the ability to concatenate theoretical and everyday approaches of modern physics but there is virtually no material directed to teachers and students of basic education. And smaller still is the number of reported experiences of approach to this branch of physics in schools. This master's dissertation presents a portable experimental apparatus for use in classroom, a Crookes' tube, and theoretical teaching materials, published as a site for the introduction of plasma physics in elementary and high school and for the basic understand of the experiment. It also can be used for higher education. The courseware was developed with a focus on historical conceptual evolution, and also the techniques and technologies, leading to the identification and characterization of the so-called fourth state of matter. It avoided the use of mathematical development as a way for the construction of concepts, although some was necessary. The load concepts and electric current, electric and magnetic fields, temperature and transition phases are taken as needed prerequisites the chain of classes as proposed. The experimental class may happen at any time. It thus removes the need for mathematical prerequisites, such as differential equations, for understanding of modern concepts such as the Debye length and plasma frequency, making the use of analogies and indicated concepts. We obtained a concise material and instructional appeal capable of capturing the students' attention to the importance of the study of physics and plasma physics presence in day-to-day lives, then showing that the concepts of science are close to them and that are in development, which brings a sense of closeness between the frontier of science and everyday life. This gives conditions for future conceptual improvements and prompting the search for knowledge.
\end{abstract}

Keywords: plasma physics, Crookes' tube, eletrical discharge in gases, basic education, technology, up to date, historical development. 


\section{Lista de Figuras}

Figura 1: Esfera de Debye.

Figura 2: Deslocamento de elétrons.

Figura 3: Representação da lâmpada fluorescente.

Figura 4: Típico processo de recombinação.

Figura 5: A energia do fóton determina sua cor.

Figura 6: Absorção de energia e emissão de luz.

Figura 7: Típica célula de monitor a plasma. Esboço inicial.

Figura 8: Curvas de Pasche para tubos de descarga mais usados.

Figura 9: Avalanche de Townsend.

Figura 10: Regime das descargas elétricas.

Figura 11: Regiões do tubo de Crookes.

Figura 12: Perfil do potencial elétrico entre os eletrodos.

Figura 13: Detalhamento das regiões de luminescencia, da intensidade do brilho, do campo e do potencial elétrico entre os eletrodos.

Figura 14: Esboço inicial.

Figura 15: Desembalando o tubo de borosilicado.

Figura 16: Tubo de borosilicado feito sob encomenda para o projeto.

Figura 17: Desenho técnico da flange A.

Figura 18: Visão em 3D da flange A com textura de alumínio 7050. 
Figura 19: Desenho técnico da flange B.

Figura 20: Visão em 3D da flange B com textura de alumínio 7050.

Figura 21: Modelo em 3D projetado do tubo em vidro borosilicato com as flanges e contraflanges encaixadas.

Figura 22: Equipamento montado em teste de bancada.

Figura 23: Primeira eletrização do tubo de descargas.

Figura 24: Primeira luminescencia gerada, plasma no tubo de descargas. 


\section{Lista de Gráficos}

Gráfico 1: Em azul, "sim", em vermelho, "não": respostas à pergunta 7 "Você gosta de estudar física?", antes e após as aulas.

Gráfico 2: Em azul, "sim", em vermelho, "não": respostas à pergunta 1 - "No contexto da física, você sabe o que é plasma?", antes e após as aulas.

Gráfico 3: Em azul, "sim", em vermelho, "não": Quantidade de Alunos que afirmam saber o que há no interior de uma lâmpada fluorescente pergunta 2.

Gráfico 4: Em azul, "sim”, em vermelho, "não": Quantidade de alunos que afirmam, sim, saber, ou não, como funciona uma lâmpada fluorescente - pergunta 2.1.

Gráfico 5: Em azul, "sim", em vermelho, "não": Quantidade de alunos que afirmam, sim ou não, terem ouvido falar em fusão termonuclear pergunta 3.

Gráfico 6: Em azul, "sim", em vermelho, "não": Quantidade de alunos que afirmam, sim ou não, saberem o que é um Tokamak - pergunta 4.

Gráfico 7: Em azul, "sim", em vermelho, "não": Quantidade de alunos que afirmam, sim ou não, saberem o que é um tubo de raios catódicos - pergunta 5.

Gráfico 8: Em azul, "sim", em vermelho, "não": Quantidade de alunos que afirmam, sim ou não, pensarem em trabalhar em alguma profissão que utilize o estudo da física diariamente - pergunta 8. 


\section{Lista de Tabelas}

Tabela 1: Amplitude dos parâmetros de plasma.

Tabela 2: Compilação dos resultados gerais dos testes. 


\section{Sumário}

Agradecimentos Especiais......................................................... vi

Capítulo 1 - Introdução .............................................................. 15

Capítulo 2 - Proposição.................................................................. 18

Capítulo 3 - Destaques Históricos e Caracterização de Plasma...................26

Capítulo 4 - Aplicação................................................................ 43

Capítulo 5 - Resultados da Aplicação...............................................53

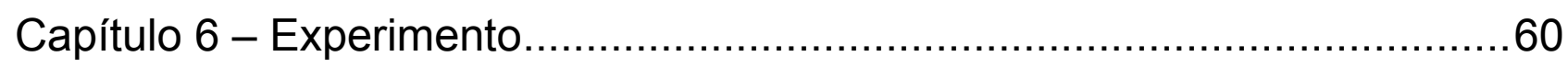

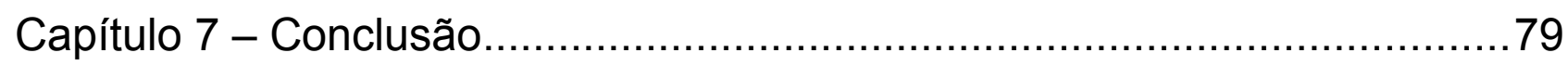

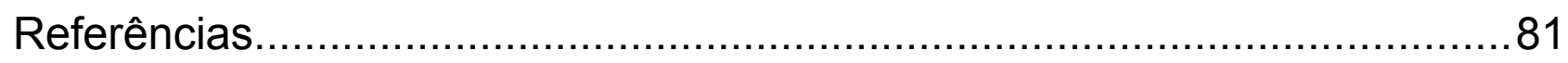

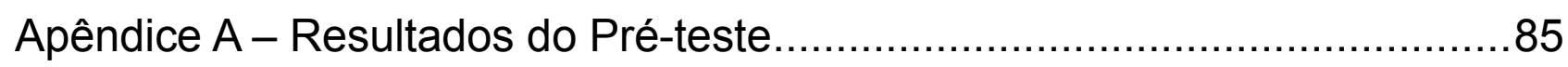

Apêndice B - Resultados do Pós-teste...............................................91 


\section{Capítulo 1 - Introdução}

Este trabalho consiste na apresentação de dois produtos educacionais visando possibilitar o ensino de física de plasmas no ensino básico. São eles: um site sobre física de plasmas e um experimento portável para demonstração da produção de plasma que é um tubo de Crookes, ou tubo de descarga elétrica em gases a baixa pressão, além de outras possíveis explorações.

Ele é resultado da inspiração promovida pelos diversos trabalhos desenvolvidos desde 1996, e também pelos que ainda estão em andamento, no Laboratório de Plasmas da Universidade de Brasília, como a máquina de confinamento por espelhos magnéticos, o equipamento para eliminação de poluentes, os propulsores espaciais do tipo P-Hall e do tipo Helicon Double Layer Thruster (HDLT), entre outros. Também como consequencia da ambição formativa promovida por trabalhos de iniciação científica, como em VENCESLAU e FONSECA (2000), e outros (LIMA, VENCESLAU e NUNES, 2002), (LIMA, VENCESLAU e BRASIL, 2014), que mostraram possíveis e enriquecesoras explorações de temas usuais na sala de aula.

O primeiro produto foi desenvolvido em parceria com o mestrando Rodrigo Pacios de Andrade, em razão da convergência temática dos trabalhos, e foi aplicado em sala de aula a uma turma do terceiro ano do ensino médio do Colégio Dromos, em Brasília. Ele encontra-se publicado em: <http://rodrigoegustavo.wix.com/fisicadeplasmas> e tem servido, desde seu lançamento, como fonte de consulta de estudantes e professores do ensino médio. Impressões das páginas do portal estão no Apêncice C. Foram aplicados testes qualitativos à turma e seu registro completo pode ser encontrado no Apêncice $A$, para o pré-teste, e Apêncice $B$, para o pós-teste.

O segundo produto, um tubo de descargas elétricas em gás a baixa pressão, um grande tubo de Crookes, encontra-se pronto e em funcionamento, sua aplicação em sala de aula resultou prejudicada em razão de uma dessincronia com o calendário do ensino médio e a finalização de sua montagem, boa parte dela em função de inúmeras paralizações ocorridas nos serviços da Universidade de Brasília, ao longo do período $2013-2015$. 
Sendo uma montagem inédita projetada especificamente para este trabalho houve necessidade da produção de peças únicas que atendessem sua especificidade. Os desenhos das flanges - peças de metal usadas para conectar tubos e dutos com distintos diâmetros - foram elaborados de modo que, uma vez montadas, elas também possibilitassem a realização de outros experimentos com plasma, como o uso de diferentes gases para sua produção, a aplicação de campos magnéticos variáveis por meio do uso de bobinas - garrafa magnética, a coleta de dados para a medida da temperatura de plasma - sonda de Langmuir, entre outros. Ao longo do desenvolvimento do projeto houve a disponibilização por um dos maiores centros

Houve, desde o início do projeto, uma cuidadosa atenção em se produzir um equipamento com considerável versatilidade, dadas eventuais limitações orçamentárias e de produção, deixando-o pronto para o desenvolvimento de outros projetos do Mestrado Nacional em Ensino de Física sem limitar o seu uso para a presente aplicação proposta.

Atualmente o tubo de descargas encontra-se em pleno funcionamento e já foi utilizado por uma turma da disciplina Introdução à Física de Plasmas do Instituto de Física da UnB no segundo semestre de 2015. O histórico de sua montagem está relatado por meio de figuras no Apêndice D.

Ao longo do desenvolvimento deste projeto houve a disponibilização por um dos maiores centros de pesquisa em física de plasma do mundo, o Princeton Plasma Physics Laboratory, de um experimento como esse para operação em tempo real pela internet, disponível em: <http://scied-web.pppl.gov/rgdx/>.

Esse texto apresenta a proposição do projeto desenvolvido no capítulo 2, seguida de uma breve revisão teórica no capítulo 3, composta de: antecedentes e contextos históricos que levaram ao uso do termo "plasma", a caracterização do plasma e a cronologia de contribuições marcantes e a relação de alguns dos cientistas responsáveis por elas, todos com aprofundamento relativo a uma abordagem direcionada ao ensino básico, fundamental e médio.

Os capítulos 4 e 5 são dedicados à aplicação realizada em sala de aula e à análise de seus resultados respectivamente. No capítulo 6 é detalhado o aparato experimental e o experimento que motivou seu desenvolvimento. $E$, finalmente, no 
capítulo 7 é apresentada a conclusão deste trabalho.

Espera-se com ele incentivar colegas professores e estudantes de graduação e pós-graduação a contribuir de forma colaborativa para a consolidação da inserção de temas de física moderna e contemporânea a partir da introdução do estudo de física de plasma nos currículos do ensino básico, além disso, entregar conteúdo a ser usado em aulas do ensino médio e um experimento demonstrativo para a comunidade escolar. 


\section{Capítulo 2 - Proposição}

De acordo com recentes resultados observacionais em astronomia e com o modelo da Cosmologia moderna que melhor se ajusta a eles, o modelo cosmológico padrão ^CDM (modelo Cold Dark Model, "matéria escura fria", acrescido da constante $\Lambda$ ), o Universo é composto por $71,8 \%$ (setenta e um por cento e oito décimos) de energia escura, $23,6 \%$ (vinte e três por cento e seis décimos) de matéria escura e 4,6\% (quatro por cento e seis décimos) de matéria visível ou bariônica, (FROÉS, 2014).

No ensino básico a matéria visível constituinte do universo é estudada basicamente em três estados: sólido, líquido e gasoso. Plasma, o quarto e mais abundante estado da matéria bariônica (FITZPATRICK, 2014, p. 1), é pouco ou nada abordado (TAVARES, HORA, 2009) (ANDRADE, em fase de elaboração)'1.

Espera-se com este trabalho mostrar a factibililidade de inserção de conteúdos de física moderna e contemporânea, especificamente apresentação e caracterização do estado plasma, no ensino médio. Para tanto, propõe estabelecer um vínculo entre conhecimentos prévios dos estudantes e: (i) a contextualização histórica que levou à caracterização do estado plasma, relacionando alguns equipamentos usados em experimentos antigos e em experimentos atuais; (ii) a necessidade de se compreender melhor alguns fenômenos naturais terrestres atmosféricos e proximais, fenômenos espaciais e estelares; (iii) a possibilidade de melhor compreender os princípios de funcionamento de alguns equipamentos comuns no dia-a-dia; (iv) a possibilidade de interagir com um experimento demonstrativo de produção de plasma.

Pois como afirma TERRAZZAN (1992, p. 210):

"Aparelhos e artefatos atuais, bem como fenômenos cotidianos em uma quantidade muito grande, somente são compreendidos se alguns conceitos estabelecidos a partir da virada deste século forem utilizados."

1 Resultado de levantamento elaborado pelo discente do MNPEF - Polo 1, Rodrigo Pacios de Andrade em livros didáticos de física, adotados no Brasil e em outros países, como parte do seu projeto de dissertação. 
Inserir conteúdo de física de plasma no ensino médio pode parecer um desafio distante da realidade escolar do ensino básico. Mas, desde que se assuma uma abordagem conceitual focada nas interrelações com outros tópicos de física e de química estudados no ensino médio, e.g. cinética de gases e efeito fotoelétrico, abordar este ramo da ciência pode representar uma ponte com diversos outros como a físico-química de filmes finos, astronomia, cosmologia, física de partículas, etc., permitindo a inserção e abordagem de tantos outros conhecimentos da ciência moderna e contemporânea.

Assim espera-se também disponibilizar conteúdo de forma que venha a contribuir na promoção de aprendizagem substantivamente significativa, induzindo e estimulando o caminhar efetivo de estudantes na direção do aprimoramento científico, técnico e tecnológico, e por fim à inovação, contribuindo para a formação de cidadãos com acesso ao conhecimento humano do século XX. E também possibilitar aos estudantes observar a mudança controlada dos estados físicos de gasoso para plasma em sala de aula.

Quanto a substantividade, o que se propõe é o que está indicado por MOREIRA (1999, p.75) "[...] para facilitar a aprendizagem significativa é preciso dar atenção ao conteúdo e à estrutura cognitiva, procurando 'manipular' os dois."

Para tanto foi elaborada uma página na internet contendo a compilação de conteúdo destinado a indicar a professores e alunos um possível caminho para o desenvolvimento de alguns conceitos fundamentais da física de plasma, que, espera-se, seja útil tanto para a elaboração de planos de aula como para fonte de consulta pelos alunos.

Também foi desenvolvido um aparato experimental demostrativo portável que pode ser levado a qualquer escola com rede elétrica. Esse aparato pode ser comparado ao que se conhece como Tubo de Crookes, pelo modo de geração do plasma, mas que na verdade permite um exploração experimental mais ampla.

O equipamento conta com cinco aberturas em cada flange - nome de qualquer peça que conecte tubos com diferentes diâmetros - uma bomba mecânica de vácuo, medidores de vácuo, fontes de potência e correntes elétricas controladas.

Na montagem do aparato utilizou-se equipamentos fora de uso do Laboratório de 
Plasma do Instituto de Física da UnB bem como peças desenhadas pelo mestrando e manufaturadas pela Oficina Mecânica do Instituto de Física além de outras adquiridas pelo Laboratório de Plasmas.

Com o experimento, espera-se estimular professores e alunos ao estudo da física de um modo geral e física moderna de modo específico com o apoio de textos instrucionais, aos professores(as), e didático-orientadores, aos estudantes. Estes textos, contidos no site, indicam: um breve histórico da evolução conceitual que levou à consolidação do termo que dá nome a esse ramo da física; onde encontrar plasma no meio ambiente terrestre, nos equipamentos e instrumentos eletro-eletrônicos que nos servem e também no espaço; apresentam os desafios enfrentados pela pesquisa de ponta; e por fim algumas soluções tecnológicas que vem sendo entregues pela física de plasma à humanidade.

A evolução histórica do conceito de plasma é uma estratégia possível para apoio da interação com o experimento. Segundo MATTHEWS (1995), para Ernst Waldfried Josef Wenzel Mach (1883-1960) e seguidores, é necessário que se compreenda o desenvolvimento histórico de um conceito para que ele seja compreendido, ou seja, a compreensão é necessariamente histórica. Mach, citado em MATTHEWS (1995, p.169), afirma que:

“ 'A investigação histórica do desenvolvimento da ciência é extremamente necessária a fim de que os princípios que guarda como tesouros não se tornem um sistema de preceitos apenas parcialmente compreendidos ou, o que é pior, um sistema de pré-conceitos. A investigação histórica não somente promove a compreensão daquilo que existe agora, mas também nos apresenta novas possibilidades (Mach, 1883/1960, p. 316).' "

Ao unirem-se as potencialidades de ensino e aprendizagem desses recursos, contextualização histórica, compreensão do funcionamento de equipamentos contemporâneos e experimento, espera-se dar condições para que seja criada uma proposta de sequência didática, fundamentada em teorias de aprendizagem, particularmente a da aprendizagem significativa. 
Partindo das premissas de que não há ensino sem aprendizagem, de que o ensino é o meio e a aprendizagem é o fim, essa sequência é proposta como sendo uma Unidade de Ensino Potencialmente Significativa (UEPS) (MOREIRA, 2012).

O grande desenvolvimento técnico-científico notado entre os anos 1700 e 1899 proporcionou bases conceituais e materiais para a Revolução Tecnológica ocorrida ao longo do século XX.

A Revolução Tecnológica do século XX lança inúmeros desafios ao tempo atual à medida que possibilitou formas de comunicação de baixo custo entre quaisquer humanos sobre a Terra através da internet. Junto a isso, grandes acervos informacionais estão à distância de um clique na rede mundial de computadores. Assim o professor em sala de aula se depara com alunos super estimulados pelos mais diversos aparatos tecnológicos, com smartphones que verdadeiramente são computadores de mão, com acesso rápido a informações, portanto capazes de responder aos alunos de forma muito mais ágil, precisa e com um nivel de detalhamento que somente os mais experientes e bem preparados professores conseguem superar.

Nesse contexto, o professor do ensino médio parece travar um embate desigual ao apresentar conteúdos com baixo nível de correlação ou de visualização no cotidiano dos alunos. Esta correlação parece diminuir à medida que o assunto abordado se distancia do mundo macroscópico rumo à escala microscópica, do mundo mecânico ao eletrônico.

Com a finalidade de promover a correção necessária das disparidades existentes entre o ensino de ciências focado primordialmente em teorias desenvolvidas, em sua grande parte, até o século XIX e a realidade tecnológica dos séculos $X X$ e $X X I$ presente na vida do cidadão médio, diversos aprimoramentos educacionais e legais têm sido propostos e, de alguma forma, consolidados em diversas normas, como as apresentadas a seguir.

É um reconhecimento que extrapola o meio acadêmico e de ensino. A formulação de novas redações nas leis, incluindo as inserções no texto constitucional brasileiro (BRASIL, 1988), representam a força desse reconhecimento pela sociedade brasileira. E exige investimentos de toda ordem. 
A inserção do estudo de física de plasma nos currículos possibilita a exploração de inúmeros tópicos de física, desde modelos da evolução cósmica até a criação de novos materiais, produtos e tecnologias. Em uma abordagem articulada e próxima do mundo vivido pelos alunos, que possibilita o uso de exemplos reais e a compreensão de princípios de funcionamento de tecnologias presentes no cotidiano de alunos e professores. Permite uma contextualização sócio-cultural como previsto nos Parâmetros Curriculares Nacionais - Ensino Médio, parte III: Ciências da Natureza, Matemática e suas Tecnologias (PCN, 2000, pág.29):

- Reconhecer a Física enquanto construção humana, aspectos de sua história e relações com o contexto cultural, social, político e econômico.

- Reconhecer o papel da Física no sistema produtivo, compreendendo a evolução dos meios tecnológicos e sua relação dinâmica com a evolução do conhecimento científico.

- Dimensionar a capacidade crescente do homem propiciada pela tecnologia.

- Estabelecer relações entre o conhecimento físico e outras formas de expressão da cultura humana.

- Ser capaz de emitir juízos de valor em relação a situações sociais que envolvam aspectos físicos e/ou tecnológicos relevantes.

Além de perpassar os seis temas estruturadores previstos nas Orientações Educacionais Complementares aos Parâmetros Curriculares Nacionais - Física (PCN+ Ensino Médio, 2000, pág. 19):

Movimentos: variações e conservação;

Calor, ambiente, fontes e usos de energia;

Equipamentos eletromagnéticos e telecomunicações;

Som, imagem e informação;

Matéria e radiação;

Universo, Terra e vida.

Assim o estudo de física de plasma tem a capacidade de promover uma abordagem interdisciplinar estruturada, relacionando teoria e prática, estimulando o interesse pelas áreas de ciência e tecnologia, do espaço ao laboratório, e também ao cotidiano do estudante. 


\section{A Emenda Constitucional nº 85 de 2015}

A Emenda Constitucional $n^{\circ} 85$ (EC $\left.n^{\circ} 85\right)$, de 26 de fevereiro de 2015, alterou e adicionou dispositivos constitucionais para as atividades de ciência, tecnologia e inovação, atualizando o tratamento dado a elas. Foram incluídas nas competências comuns da União, Estados e Municípios, proporcionar meios de acesso à ciência, à tecnologia, à pesquisa e à inovação (art.23, inciso V), e também, legislar concorrentemente sobre estes e também sobre o desenvolvimento científico e tecnológico (art. 24, inciso IX), (BRASIL, 1988).

Em assuntos orçamentários, a EC $\mathrm{n}^{\circ} 85$ tornou admissível ato do Poder Executivo, sem necessidade de autorização legislativa prévia, o que não é permitido de um modo geral, a "transposição, o remanejamento ou a transferência de recursos (financeiros) de uma categoria de programação (orçamentária) para outra", "no âmbito das atividades de ciência, tecnologia e inovação, com o objetivo de viabilizar os resultados de projetos restritos a essas funções" (167, §5º), (BRASIL, 1988).

Sobre a destinação dos recursos públicos, foram ampliadas as atividades de pesquisa e extensão com a EC $\mathrm{n}^{\circ}$ 85, deixando de restringir-se às universidades passando a englobar instituições de educação profissional e tecnológica e também atividades de estímulo e fomento à inovação (art. 213, §2º), (BRASIL, 1988).

Por fim, no Título da Ordem Social, a EC n 85 traz nova redação ao Capítulo IV que passa a tratar da Ciência, Tecnologia e Inovação, incluído o último, com a revisão, adequação e inclusão de artigos e parágrafos sobre o tema, (BRASIL, 1988).

\section{A LDB}

A Lei de Diretrizes e Bases da Educação (LDB), lei n 9.394, de 20 de dezembro de 1996, prevê em seu artigo 35 que o ensino médio terá como uma de suas finalidades "a compreensão dos fundamentos científico-tecnológicos dos processos produtivos, relacionando a teoria com a prática, no ensino de cada disciplina”, (BRASIL,1996). A redação do artigo 36 é explicita quanto às diretrizes a serem observadas pelo currículo do ensino médio. A primeira diretriz indica que o currículo: 
“ [...] destacará a educação tecnológica básica, a compreensão do significado da ciência, das letras e das artes; o processo histórico de transformação da sociedade e da cultura; a língua portuguesa como instrumento de comunicação, acesso ao conhecimento e exercício da cidadania". (BRASIL,1996, grifo nosso).

E ainda neste artigo consolida o quê se espera que o educando demonstre ao final do ensino médio "domínio dos princípios científicos e tecnológicos que presidem a produção moderna" e "conhecimento das formas contemporâneas de linguagem", para atingir estes objetivos deverão ser organizados os conteúdos, as metodologias e as formas de avaliação. Importante destacar que a educação profissional técnica de nível médio também atende à formação geral do educando do ensino médio.

\section{O Plano Nacional de Educação}

O Plano Nacional de Educação (PNE) para a década de 2014-2024 aprovado pela lei $n^{\circ} 13.005$, de 25 de junho de 2014, tem como uma de suas diretrizes a promoção científica e tecnológica do País, dentre outras. Estabelece na meta 3 a universalização do atendimento escolar, até 2016, para toda a população de 15 (quinze) a 17 (dezessete) anos e prevê, para até 2024, a elevação da taxa líquida de matrículas no ensino médio para $85 \%$ (oitenta e cinco por cento), (BRASIL, 2014). Para tanto BRASIL (2014) indica como estratégias:

"3.1 - institucionalizar programa nacional de renovação do ensino médio, a fim de incentivar práticas pedagógicas com abordagens interdisciplinares estruturadas pela relação entre teoria e prática, por meio de currículos escolares que organizem, de maneira flexível e diversificada, conteúdos obrigatórios e eletivos articulados em dimensões como ciência, trabalho, linguagens, tecnologia, cultura e esporte, garantindo-se a aquisição de equipamentos e laboratórios, a produção de material didático específico, a formação continuada de professores e a articulação com instituições acadêmicas, esportivas e culturais; [...]

3.14) estimular a participação dos adolescentes nos cursos das áreas tecnológicas e científicas." (grifos nosso). 
Outra frente de expansão de matrículas no ensino médio também está prevista na meta 11 que indica "triplicar as matrículas da educação profissional técnica de nível médio, assegurando a qualidade da oferta e pelo menos $50 \%$ (cinquenta por cento) da expansão no segmento público", BRASIL (2014).

A meta 14 indica que se deve elevar o número de matrículas na pós-graduação stricto sensu para que a titulação anual chegue a 60.000 (sessenta mil) mestres e 25.000 (vinte e cinco mil) doutores, BRASIL (2014).

Para o cumprimento não só das metas aqui reproduzidas mas também das outras, há previsão, na meta 20 , de ampliação do:

"[...] investimento público em educação pública de forma a atingir, no mínimo, o patamar de 7\% (sete por cento) do Produto Interno Bruto PIB do País no $5^{\circ}$ (quinto) ano de vigência desta Lei e, no mínimo, o equivalente a $10 \%$ (dez por cento) do PIB ao final do decênio." (BRASIL, 2014, grifos nosso).

O que segundo análise realizada por SANTOS (2014) é insuficiente para garantir o cumprimento das demandas do PNE pela educação pública, uma vez que a contabilização dos custos com matrículas das parcerias público-privadas reduz a 8\% (oito por cento) do PIB a disponibilidade para a educação pública, sendono mínimo para o seu funcionamento $10 \%$ (dez por cento) do PIB. 


\section{Capítulo 3 - Destaques Históricos e Caracterização de Plasma}

O estudo de descargas elétricas obtidas pela eletrização por atrito ao longo dos séculos XVII e XVIII resultou na invenção e aprimoramento de diversos aparatos de eletrização, acúmulo e armazenamento de eletricidade, (ASSIS, 2010; HEILBRON, 1979). Também lançou bases para o grande desenvolvimento tanto teórico quanto experimental que o tema sofreu por todo o século seguinte, culminando com a identificação da relação massa carga (THOMSON, 1897) da partícula considerada como a portadora da carga elétrica elementar para o ensino de eletricidade na educação básica.

O aprimoramento dos experimentos, das técnicas de produção dos aparatos e a evolução na compreensão dos fenômenos observados também criaram condições para a identificação (CROOKES, 1879) e a caracterização (LANGMUIR, 1929) do quarto estado da matéria entre o último quarto do século XIV e a primeira metade o século $X X$, respectivamente.

Naturalmente, não apenas o entendimento sobre eletricidade evoluiu nesses períodos. A vinculação com o magnetismo, cujo desenvolvimento caminhou junto com o da eletricidade (ASSIS, 2010; HEILBRON, 1979) e a melhor compreensão dos fenômenos térmicos, bem como da dinâmica das reações químicas, foram de fundamental importância para a compilação que representou a identificação e a caracterização precisa deste estado físico, o plasma.

O uso do termo "plasma" remonta a tempos antigos e modernamente alguns autores traçam paralelo entre os estados físicos da matéria e outros termos usados pela cultura e filosofia grega. O termo equivalente à palavra "plasma" no grego antigo era

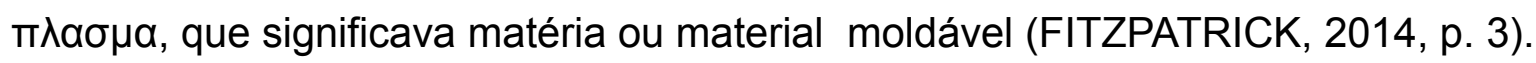

Nas ciências da natureza a palavra é usada para designar um dos quatro estados fundamentais da matéria. Uma combinação única de propriedades o distingue dos outros três estados físicos da matéria, sólido, líquido e gasoso. 


\section{Os estados físicos da matéria e os seus correlatos na Grécia antiga}

$\mathrm{Na}$ filosofia Grega antiga, muitos filósofos formaram um conjunto de elementos que acreditavam refletir as partes essenciais mais simples e os princípios a partir dos quais qualquer coisa seria constituída.

Para alguns, como Aristóteles e seus seguidores, eram cinco os elementos básicos, sendo eles a terra, a água, o ar, o fogo e o éter. Recentemente em livros de ciências são encontradas correlações entre esses elementos e os estados físicos da matéria.

Sendo a terra correspondente aos estado sólido, a água ao estado líquido, o ar ao estado gasoso, o fogo ao estado plasma e o éter por hora abandonado ou substituído por algum outro conceito ainda não correlacionado.

Como afirma BALL (2004, p.12):

"Apesar de uma tendência a superestimar a primazia do esquema de quatro elementos - existiram, como temos visto, muitos outros essa ideia avança em direção a explicar a longevidade dos elementos de Empédocles. Eles se encaixam, eles concordam com nossa experiência diária. Eles distinguem diferentes tipos de matéria. O que isso realmente significa é que os elementos clássicos são representantes familiares de diferentes estados que a matéria pode adotar. A terra representa não apenas o solo ou pedras, mas os sólidos. A água é o arquétipo de todos os líquidos; o ar, de todos os gases e vapores. O fogo é estranho, pois na verdade é um único e impactante fenômeno. Fogo é na verdade um plasma dançante de moléculas e fragmentos de moléculas, excitados em um estado brilhante pelo calor." 


\section{Observação do quarto estado da matéria}

Ao longo dos séculos XVII e XVIII diversos aparatos foram desenvolvidos para a eletrização por atrito, acumulação e descarga de eletricidade. O "ovo elétrico" um equipamento criado por Jean Antoine Nollet (1700-1770), também conhecido por Abbé Nollet (JEAN, 2015), foi aprimorado e experimentos conduzidos por Masson, Grove e Johann Willhelm Hittorf (1824-1914) possibilitaram a Johann Heinrich Wilhelm Geissler (1814-1879) difundir, a partir de trabalhos produzidos por seu irmão Friederich ao químico holandês Volkert Simon Maarten van der Willigen (1822-1878) o uso de tubos de vidro selados e contendo gases a baixa pressão para estudo de descargas elétricas em seu interior (GEISSLER, 2015).

Em 1878, William Crookes (1832-1919) publicou um longo artigo (CROOKES, 1878), relatando a realização e reprodução de experimentos mostrando efeitos observados em gases com diferentes pressões e temperaturas no interior de tubos de vidro parecidos com as ampolas de Geissler, que sofreram aprimoramentos por Julius Plücker (1801-1868) e outros ao longo daquele século, e que mais tarde, e ainda hoje, são conhecidos como tubos de Geissler e de Crookes.

Nesse artigo, CROOKES (1878) relata a indução de corrente através de gases rarefeitos e discorre sobre: o espaço escuro em torno do polo negativo, a iluminação das linhas de pressão molecular, os radiômetros elétricos, a convergência de raios moleculares para um foco, a luz fosforescente verde de impacto molecular, o foco da energia molecular, a natureza da luz fosforescente, a projeção de sombras moleculares, a fosforescência de filmes finos, a ação mecânica de moléculas projetadas, a deflexão magnética de linhas de força molecular, a trajetória de moléculas, a alteração de velocidades moleculares, as leis da deflexão magnética, o foco do calor molecular de impacto e sobre um estado da matéria ultra gasoso.

Àquela época ainda não havia sido identificado o elétron, portanto, creditava-se às moléculas as propriedades e efeitos encontrados, que hoje atribuimos serem produzidos pelos elétrons.

Mesmo assim, Crookes prenunciou o que se mostraria ser, anos mais tarde, a identificação do estado em que se encontra grande parte de nosso universo visível: 
"Os fenômenos nesses tubos de descarga revelam para a ciência física um novo mundo - um mundo aonde a matéria pode existir em um quarto estado, aonde a teoria corpuscular da luz pode ser verdadeira, e aonde a luz nem sempre se move em linhas retas, mas aonde nunca poderemos entrar, e o qual precisamos nos contentar em observar e experimentar pelo lado de fora." (CROOKES, 1878, p. 164, tradução nossa).

Com o desenvolvimento ao longo dos séculos XVII e XVIII de equipamentos capazes de armazenar carga elétrica (ASSIS, 2010), o estudo dos fenômenos elétricos e magnéticos ganhou cada vez mais espaço, até ocupar o centro do palco da comunidade científica no século XIX.

Esse fenômenos foram então sistematica e metodicamente combinados em uma só teoria eletromagnética (MAXWELL, 1873), culminando esse prolífico período de pesquisa científica com, dentre outras, a proposição em 1897 por Joseph John Thomson (1856-1940) da existência de uma partícula massiva portadora de carga elétrica nos raios catódicos (THOMSON, 1897), mais tarde batizada de elétron. Segundo FALCONER (1987) citada por ARABATZIS (1996), Thomson não seria o único que estaria investigando os raios catódicos na busca pela determinação da relação carga-massa.

Os experimentos desenvolvidos nessa época também deram acesso ao estado mais energético da matéria, o plasma, que revelou sua fenomenologia dentro dos tubos de Geissler e Crookes, confirmando o que a percepção primitiva indicava ao conhecimento humano já na Grécia antiga, que o fogo pertencia a uma categoria de matéria diferente da terra, da água e do ar.

\section{Nomenclatura e descrição do estado plasma}

A primeira definição formal do estado plasma foi elaborada por Irving Langmuir (1881 - 1957) quando ele vinha estudando, nos laboratórios da General Eletric nos Estados Unidos da América, a temperatura de elétrons em gases ionizados a baixa pressão, e procurava entender porque a distribuição maxwelliana de velocidades de elétrons livres correspondia a temperaturas no intervalo de 5.000 a 60.000 Kelvin 
Entretanto, para LANGMUIR (1928), o livre caminho médio dos elétrons deveria ser tão grande que colisões comuns não poderiam gerar esse tipo de distribuição, Maxwelliana. Pois, segundo ele, os elétrons, inicialmente acelerados pelo cátodo quente, que formavam originalmente um feixe com velocidade de translação uniforme, rapidamente adquiriam um movimento ou temperatura aleatória, que deveria resultar de impulsos aplicados aos elétrons em direções randômicas. Ele suspeitou que oscilações elétricas de alta frequência e pequeno comprimento de onda poderiam produzir tal espalhamento em direções aleatórias.

LANGMUIR (1928) afirma que foi Ditmer quem previu que as oscilações deveriam ser da ordem de $10^{8} \mathrm{~Hz}$, no entanto, ele no entanto não foi capaz de medi-las nem de oferecer uma explicação para sua origem. Segundo ele, foi Frans Michel Penning (1894 1953) quem mediu essas oscilações, no intervalo de $3 \times 10^{8}$ a $6 \times 10^{8} \mathrm{~Hz}$, mas também não sugeriu uma causa possível.

As observações de Penning foram confirmadas por LANGMUIR (1928) e seu colega Lewi Tonks (1897-1971), e, assim, formularam sua hipótese: quem oscilava eram os elétrons, sendo comprimidos e descomprimidos de maneira análoga as ondas sonoras. Com a exceção das regiões próximas aos cátodos, aonde existem bainhas com poucos elétrons, o gás ionizado contém quantidades semelhantes de íons e elétrons, tornando a carga resultante quase nula.

LANGMUIR (1928) nomeia esta região aonde as cargas de íons e elétrons estão balanceadas de plasma pela forma que um fluido eletrificado carregava íons e elétrons.

Uma característica conceitualmente necessária para a determinação do estado plasma é o efeito de blindagem de Debye. Essa é uma consequência teorizada por Peter Debye (1884-1966) e Erich Hückel (1896-1980) no trabalho "Zur Theorie der Elektrolyte" (DEBYE, HÜCKEL, 1923), obtida após a resolução da equação de Poisson com densidade de cargas dada pela distribuição de Maxwell-Boltzmann.

O raio dessa blindagem tornou-se conhecido por comprimento de Debye (LANGMUIR, 1928, p.629) e atualmente é utilizado como um dos três parâmetros de 
caracterização de plasma (CHEN, 1974).

O comprimento de Debye deve ser muito menor que as dimensões definindo o volume ocupado pelo plasma, garantindo que o plasma seja suficientemente denso de partículas carregadas (LANGMUIR, 1928).

Segundo a teoria de Debye-Hückel aplicada por LANGMUIR (1928), qualquer campo elétrico inserido em um plasma será cancelado pelo amontoamento de partículas carregadas ao seu redor, por exemplo, caso seja inserido um íon com carga positiva, então uma maioria de cargas negativas o circundará, de modo que o campo resultante seja zero.

"[...] uma quantidade que mede a grossura da atmosfera iônica ou, para conectar com algo mais bem conhecido, a grossura de uma camada dupla de Helmholtz, prova ser uma distância característica." (DEBYE, HÜCKEL, 1923, p.191, tradução nossa).

"Se um íon movendo-se em um líquido é sujeito à influência de um campo externo, os íons ao seu redor terão de ser mover constantemente para constituir uma atmosfera iônica. Se agora assumirmos por um momento que uma carga é subitamente gerada em um eletrólito, uma atmosfera iônica terá que aparecer, o que requer certo tempo de relaxação para sua formação." (DEBYE, HÜCKEL, 1923, p.206, tradução nossa).

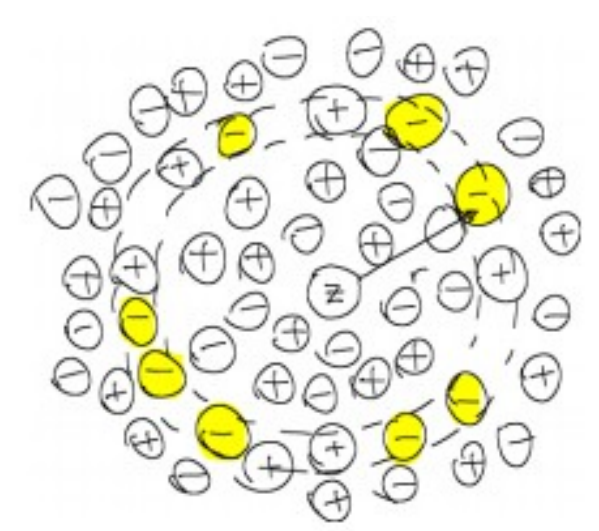

Figura 1: Esfera de Debye. Fonte: http://www-scf.usc.edu/ chem430a/scans/08.pdf

O segundo parâmetro de plasma também decorre do comprimento de Debye e é 
conhecido como blindagem de Debye. A blindagem de Debye indica que o número de partículas carregadas no interior de uma esfera cujo raio seja o comprimento de Debye deve ser muito maior do que um. O número de partículas carregadas muito maior que um no interior de uma esfera de Debye assegura que o plasma demonstre comportamento coletivo.

Como eletrólitos são cem por cento ionizados ao se dissolverem em água e o estado plasma apresenta comportamento de grupo parecido com um fluido LANGMUIR (1928) assumiu que poderia extrapolar este resultado para seus experimentos, fato que foi comprovado em seu laboratório pouco depois.

"Portanto a qualquer distância do plano (carregado) que seja grande quando comparada ao comprimento de Debye, o potencial médio e o campo elétrico médio tornam-se zero. Porém, quando o potencial do plano é alterado, um certo tempo é necessário para que a redistribuição de cargas ocorra e esses campos transientes não são dados pela teoria de Debye-Hückel." (LANGMUIR, 1928, p.628, tradução nossa).

Como afirma FITZPATRICK (2014, p. 2), "Essa foi a gênese da física de plasmas". Segundo ele a teoria elaborada a partir das pesquisas de Langmuir formam as bases teóricas para grande parte das "técnicas de iluminação com lâmpadas a base de gases ionizados em tubos de baixa pressão e do processamento a plasma para fabricar circuitos integrados".

Ainda segundo FITZPATRICK (2014), a pesquisa de plasmas teria tomado diversas direções, e o autor atribui como marco os trabalhos de Langmuir, das quais destaca cinco direções que considera particularmente importantes. Para FITZPATRICK (2014, p. 2 e 3, tradução nossa) elas são:

"Em primeiro lugar, a invenção do rádio levou à descoberta da ionosfera em 1927. Uma camada de gás parcialmente ionizado na atmosfera que reflete ondas de rádio, com comprimentos de onda maiores, alcançando altitudes mais altas. Esse fenômeno é o responsável por permitir que sinais de rádio possam ser recebidos além 
do horizonte. Para entender e melhorar a comunicação a rádio, e eventualmente inventar o radar, vários cientistas, como E. V. Appleton [1892-1965] e K.G. Budden, sistematicamente desenvolveram a teoria de propagação de ondas eletromagnéticas em plasmas magnetizados não-uniformes.

Os astrofísicos rapidamente reconheceram que muito do universo consistia de plasma, sendo essa a segunda importante direção de pesquisa. O pioneiro nessa área foi Hannes Alfvén que, em torno de 1940, desenvolveu a teoria da magnetohidrodinâmica (MHD), em que plasmas são tratados essencialmente como fluidos condutores. Essa teoria teve grande sucesso na investigação de manchas solares, vento solar, explosões solares, jatos galáticos, formação de estrelas e uma gama de outros tópicos na astrofísica. O campo magnético terrestre é mantido pelo movimento de seu núcleo derretido, que pode ser aproximado como um fluido MHD.

A criação da bomba de hidrogênio em 1952 traz a terceira grande área a se desenvolver após os estudos de Langmuir. Um grande interesse em obter fusão termonuclear controlada como fonte de energia para o futuro se criou, sendo as pesquisas nesta área desenvolvidas em segredo, independentemente pelos Estados Unidos, União Soviética e Grã-Bretanha. No entanto, em 1958 a pesquisa nessa área foi revelada ao público, levando à publicação de um número imenso de importantes e influentes textos. A rigor, a física de plasmas surge então como uma disciplina matemática rigorosa. A principal preocupação dos físicos de fusão é entender como um plasma termonuclear pode ser confinado, em geral, utilizando campos magnéticos, e investigar as instabilidades que o permitem escapar [de uma região de confinamento]."

Uma importante direção das pesquisas da física de plasma aplicada deixou de ser mencionada por FITZPATRICK (2014) que é o uso de plasma na propulsão eletromagnética, ou a plasma. Este tipo de propulsão permite alta velocidade de exaustão do material propelente, o que reduz o seu uso (JAHN, 2002, p. 125). O que, juntamente com outras características, torna a propulsão a plasma adequada para missões de longa 
duração (JAHN, 2002, p.140). O volume de publicações sobre propulsão elétrica em geral acentuou-se a partir da década de 1950 (STUHLINGER, 1964, p. 4) mas já havia sido proposta, ao menos implicitamente, por Robert Hutchings Goddard (1882-1945) conforme registrado em seus cadernos. Segundo STUHLINGER(1964, p. 1), Goddard efetuou experimentos com um tubo de descargas elétricas em 1906.

FITZPATRICK (2014, p. 3, tradução nossa) ainda indica duas outras grandes linhas de pesquisas em física de plasma:

A quarta direção de pesquisa surge com o trabalho inovador de James A. Van Allen [1914 -2006], que colocou pela primeira vez instrumentos científicos em satélites, a saber um contador Geiger. Ao serem transmitidos pelo satélite Explorer I, os dados obtidos pelo instrumento levaram à descoberta de um cinturão de radiação ao redor da Terra, preso na magnetosfera [terrestre]. Surge assim a área de plasmas espaciais.

Finalmente, no fim dos anos 1960 são desenvolvidos lasers de alta potência, inaugurando a física de plasmas gerados por lasers. Quando um laser muito poderoso incide sobre um sólido, parte do material é imediatamente evaporado, e uma camada de plasma se forma entre o alvo e o feixe. Plasmas criados por laser tem propriedades extremas, como densidades semelhantes às de sólidos, não encontradas em plasmas comuns. Uma aplicação dessas pesquisas é a tentativa de fusão por foco de vários lasers em um pequeno alvo esférico. A física de altas energias também usa técnicas de aceleração de plasmas por lasers para reduzir o tamanho e o custo de aceleradores de partículas."

A década de 1920 trouxe consigo a caracterização rigorosa do plasma e de tão significativo, com o transcorrer do tempo, tornou-se um importante ramo da Física. Desde então, o estudo desse novo ramo da Física, a Física de Plasmas, incorpora o estado da arte da ciência que estuda os fundamentos da natureza, sendo ingrediente essencial para abrir portas a novas descobertas nos aceleradores de partículas, para suprir nossas necessidades energéticas futuras, e para o estudo do universo massivo visível, já que mais de 95\% (noventa e cinco por cento) da matéria bariônica encontra-se neste estado (FITZPATRICK, 2014, p. 1). 
A evolução da Física de Plasmas é intrinsecamente ligada ao desenvolvimento da física de tecnologia de plasmas, fundamental para a existência de uma gama de técnicas e equipamentos, como o processamento de novos materiais, televisores a plasmas, reatores para eliminação de poluentes em geral e especialmente lixo tóxico ou contaminante, como o lixo hospitalar, equipamentos de solda e corte especiais, novas pesquisas na área de Cosmologia em plasmas primordiais, astrofísica do núcleo estelar e buracos negros, fonte de energia limpa a partir da fusão controlada, etc.

A seguir é apresentado um resumo pontual com uma relação de alguns cientistas que, de alguma forma, contribuiram para a evolução da física de plasma, e os anos quando ocorreram alguma de suas marcantes contribuições. Naturalmente esses cientistas contribuiram de muitas outras formas para a ciência, essas são apenas algumas delas. Da mesma forma a relação de cientistas que assim também o fizeram para a física de plasma é extensa, uma pequena mostra é indicada nas páginas anteriores.

A intenção aqui é indicar de forma resumida a passagem, relativamente rápida, de uma época quando, aparentemente, pouco se compreendia sobre os fenômenos de descargas elétricas em gases a um tempo onde as consequencias, os ganhos técnicos e tecnológicos, pela busca do entendimento desses fenômenos já eram amplamente aplicadas para o conforto e melhoria da vida humana, como por exemplo o uso de diagnósticos de fratura por raios-x, iluminação por lâmpadas fluorescentes. O que também criou e ampliou diversos ramos de produção e comercialização de bens e equipamentos, contribuindo para a economia dos detentores das técnicas e tecnologias.

\section{Cientistas e a Cronologia de Suas Contribuições}

\section{Henrich Geissler e Julius Plucker - 1858}

Henrich Geissler foi um habilidoso físico e vidreiro (soprador de vidro) que desenvolveu junto com Julius Plücker tubos de vidro de baixa pressão interna e eletrodos (antigamente catodos) nas extremidades. O tubo que leva o nome de Geissler foi extensivamente usado ao longo do século XIX por muitos físicos e químicos e foi inventado em 1857. Plücker descobriu que os raios que o atravessavam eram defletidos se expostos a eletroimãs por volta de 1858 . 


\section{William Crookes - 1879}

William Crookes aprimorou os tubos de Geissler-Plücker ao investigar os raios catódicos mostrando que eles se propagam em linha reta, causam fluorescência quando atingem certas substâncias e podem provocar grande aumento da temperatura da superfície atingida. Ele acreditou ter descoberto o quarto estado da matéria em 1879 e o denominava "matéria radiante", mas de fato não conseguiu defini-lo com precisão, o quarto estado só foi definitivamente bem definido em 1928 por Irving Langmuir.

\section{J.J. Thomson - 1897}

Antes da descoberta de que os elétrons é que portam cargas e que são eles as particulas ejetadas de superfícies metálicas submetidas a grande diferença de potencial, acreditava-se que raios catódicos, feixes de partículas positivas, é que faziam este papel Em 1897, J. J. Thomson identificou os raios catódicos como um feixe de partículas negativamente carregadas e os denominou elétrons.

\section{Joseph Larmor - 1900}

Foi um influente físico que inovou o conhecimento da eletricidade, dinâmica, termodinâmica e teoria eletrônica da matéria. Calculou o raio da trajetória do elétron em um campo magnético, e a taxa de radiação eletromagnética de um elétron acelerado.

\section{Irving Langmuir - 1919-1928}

Famoso Químico e Físico americano, vencedor do prêmio Nobel de Química de 1932. Trabalhando com tubos de vácuo, foi um dos primeiros cientistas a estudar o plasma, nomeando-o assim em 1928. Determinou-se a configurar a temperatura e a densidade de elétrons em plasmas. Inventou a solda a plasma. 


\section{Caracterização de plasma}

A transição de fase do estado gasoso para o estado plasma pode acontecer a partir do aquecimento de um gás, ou do seu bobardeamento por elétrons, ou sujeitando-o a um forte campo eletromagnético com, por exemplo, um intenso laser ou radiação de micro-ondas. Esses processos diminuem ou aumentam o número de elétrons livres no interior do gás, e também podem ser acompanhados pela dissociação de ligações moleculares, gerando partículas positivas ou negativas, os íons.

A presença de um número não desprezível de portadores de carga, íons e elétrons, faz com que o plasma seja eletricamente condutor de modo que ele responde fortemente a campos electromagnéticos. Assim como o gás, o plasma não tem uma forma definida, ou um determinado volume, a menos quando envolto por um recipiente. Ao contrário dos gases, quando o plasma está sob a influência de um campo magnético ele pode formar estruturas, tais como filamentos, vigas e camadas duplas .

Uma forma comum de plasmas na Terra, produzido artificialmente, em tubos de descarga com gases em baixa pressão, pode ser encontrado em sinais de neon. Mesmo que a caracterização inicial tenha surgido de investigações para o aprimoramento do uso de filamentos em lâmpadas incandescentes, Langmuir (1928). Grande parte da compreensão da física dos plasmas veio da busca pelo domínio da fusão termonuclear controlada. A física de plasma fornece a base científica para a busca de fornecimento de energia a partir da fusão nuclear.

O plasma por ser um gás ionizado é suscetível a campo eletromagnéticos podendo ser moldado por eles. E essa é uma das razões para este nome: um gás moldável.

\section{Uma definição de plasma é:}

Um gás ionizado que contém elétrons livres em seu interior e é macroscopicamente neutro. 


\section{Onde encontramos plasma?}

\section{Na natureza}

Ser o estado físico mais abundante não quer dizer o mais próximo de nós ou facilmente identificável como tal. Um exemplo são as estrelas, que nos acompanham de dia e de noite. Todas elas estão no estado plasmas. No espaço rarefeito entre as galáxias também pode-se encontrar plasma. E o fenômeno da Aurora Boreal, observável nas proximidades dos pólos terrestres, que é a luminescência de plasma presente na alta atmosfera ocasionado pela aceleração das particulas carregadas nas regiões de maior intensidade do campo magnético terrestre. $\mathrm{O}$ ar no interior dos relâmpagos está no estado plasma.

\section{No cotidiano}

O plasma está nas luzes neón, nas TVs de plasma, nas soldas a plasma, nas lâmpada fluorescentes, nos jatos de exaustão dos foguetes, nos propulsores iônicos, nos arcos elétricos das lâmpadas de arco, nas bolas de plasma, nos arcos produzidos por bobinas Tesla, no disparador elétrico dos fogões a gás, nas centelhas produzidas por descarga de eletricidade estática, entre outros, os relâmpagos.

\section{No laboratório}

Grande parte da compreensão deste estado vem das pesquisas para o desenvolvimento de equipamentos que promovam a fusão nuclear. Um modelo de equipamento de fusão é o Tokamak, que é um artefato provido de um campo magnético toroidal que produz a fusão nuclear mediante o confinamento e aquecimento de plasma. 
Amplitude típica dos parâmetros de plasma: Ordens De Magnitude (ODM)

\begin{tabular}{|c|c|c|}
\hline Características & Plasmas Terrestres & Plasmas Cósmicos \\
\hline $\begin{array}{l}\text { Tamanho } \\
\text { em metros }\end{array}$ & $\begin{array}{l}10^{-6} \mathrm{~m} \text { (no laboratório) até } 10^{2} \mathrm{~m} \\
\text { (em relâmpagos) ( } ~ 8 \text { ODM) }\end{array}$ & $\begin{array}{l}10^{-6} \mathrm{~m} \text { (bainhas em espaçonaves) } \\
\text { até } 10^{25} \mathrm{~m} \text { (nebulosa intergalática) } \\
(\sim 31 \text { ODM) }\end{array}$ \\
\hline $\begin{array}{l}\text { Tempo de vida } \\
\text { em segundos }\end{array}$ & $\begin{array}{l}10^{-12} \mathrm{~s} \text { (plasma produzido por } \\
\text { laser) até } 10^{7} \mathrm{~s} \text { (lâmpadas } \\
\text { fluorescentes) ( } 19 \text { ODM) }\end{array}$ & $\begin{array}{l}10^{1} \mathrm{~s} \text { (chama solar) até } 10^{17} \mathrm{~s} \\
\text { (plasma intergalático) }(\sim 16 \mathrm{ODM})\end{array}$ \\
\hline $\begin{array}{l}\text { Densidade } \\
\text { em partículas por metro } \\
\text { cúbico }\end{array}$ & $\begin{array}{l}10^{7} \mathrm{~m}^{-3} \text { até } 10^{32} \mathrm{~m}^{-3} \text { (plasma } \\
\text { inercial confinado) }\end{array}$ & $\begin{array}{l}1 \mathrm{~m}^{-3} \text { (meio intergalático) até } 10^{30} \\
\mathrm{~m}^{-3} \text { (núcleo estrelar) }\end{array}$ \\
\hline $\begin{array}{l}\text { Temperatura } \\
\text { em Kelvin }\end{array}$ & $\begin{array}{l}\sim 0 \mathrm{~K} \text { (plasma cristalino não- } \\
\text { neutro) até } 10^{8} \mathrm{~K} \text { (plasma de } \\
\text { fusão magnética) }\end{array}$ & $\begin{array}{l}10^{2} \mathrm{~K} \text { (aurora) até } 10^{7} \mathrm{~K} \text { (núcleo } \\
\text { solar) }\end{array}$ \\
\hline $\begin{array}{l}\text { Campo Magnético } \\
\text { em Teslas }\end{array}$ & $\begin{array}{l}10^{-4} \mathrm{~T} \text { (plasma de laboratório) } \\
\text { até } 10^{3} \mathrm{~T} \text { (pasma de potência } \\
\text { pulsante) }\end{array}$ & $\begin{array}{l}10^{-12} \mathrm{~T} \text { (meio intergalático) até } \\
10^{11} \mathrm{~T} \text { (estrela de neutrôns } \\
\text { próxima) }\end{array}$ \\
\hline
\end{tabular}

Tabela 1: Amplitude dos parâmetros de plasma. Fonte: INAM e GOLKOWISK (2011), tradução nossa.

\section{Detalhando a caracterização de plasma}

As características de um gás ionizado e macroscopicamente neutro podem ser medidas precisamente pela frequência de plasma, que é a frequência com que oscilações coulombianas acontecem no interior do gás e pelo comprimento de Debye ou comprimento de blindagem de Debye, que é o tamanho ou comprimento mínimo que o plasma deve ter para manter-se eletricamente neutro macroscopicamente.

"É interessante notar que um plasma possa ter diversas temperaturas ao mesmo tempo. Frequentemente acontece de os elétrons e os íons terem distintas distribuições Maxwellianas com temperaturas $T_{e}$ e $T_{i}$ diferentes. Isto pode acontecer em virtude da taxa de colisão de íons ou de elétrons entre si ser maior que a taxa de colisão entre elétrons e íons. Então cada espécie pode estar no seu próprio equilíbrio térmico, mas o plasma pode não durar o tempo suficiente para que as duas temperaturas entrem em equilíbrio. Quando há campo magnético $\mathbf{B}$, até mesmo uma das espécies, por exemplo os íons, podem ter duas temperaturas. Isto se dá porque as forças atuando sobre um íon ao longo do campo magnético B são diferentes daquelas atuando 
perpendicularmente a $\mathbf{B}$ (devido à força de Lorentz). Os componentes da velocidade, perpendicular e paralelo a $\mathbf{B}$, devem então possuir distribuições Maxwellianas distintas com temperaturas $T_{\text {perp }}$ e $T_{\text {para }}$." (CHEN, 1974, tradução nossa).

Para se evitar uma confusão usual ao observar as altas temperaturas de um plasma, como por exemplo nas lâmpadas fluorescentes comuns, onde a temperatura do elétron é da ordem de $20.000 \mathrm{~K}$, é importante levar-se em conta a capacidade térmica do plasma ou dos objetos onde ele está confinado. Para tanto deve-se precisar a densidade de elétrons ou de íons e assim evitar a confusão.

\section{Frequência de Plasma dos elétrons}

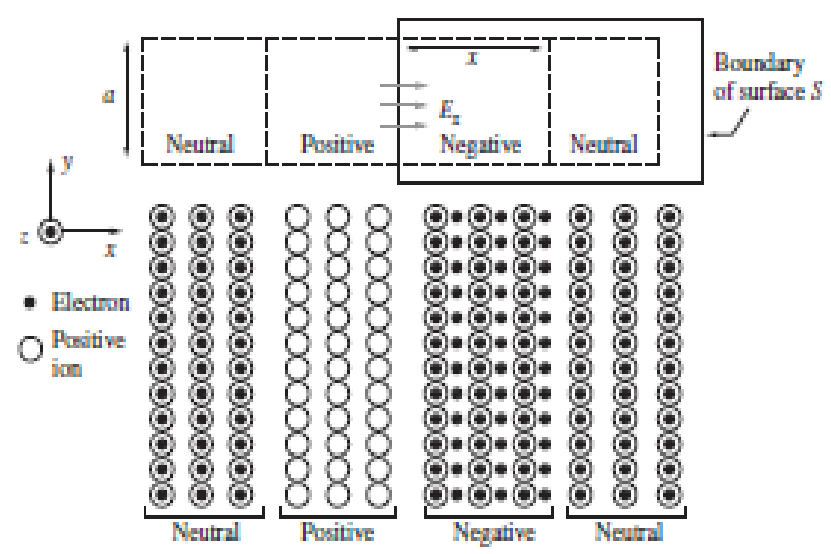

Figura 2: Deslocamento de eletrons. Fonte: INAM e GOLKOWISK (2011), tradução nossa.

Frequência de oscilação do plasma ou simplesmente frequência de plasma é a frequência com que oscilações coulombianas acontecem no interior do gás. Essas oscilações são provocadas pela força elétrica restauradora originada pelo deslocamento de elétrons da sua posicão de equilíbrio original, como esquematizado na figura acima.

A frequência de plasma $\left(\omega_{P}\right)$ é definida pela raiz quadrada da razão entre o número de elétrons $\left(N_{e}\right)$ multiplicado pela carga do elétron $\left(q_{e}\right)$ ao quadrado e o produto da constante dielétrica do vácuo $\left(\varepsilon_{0}\right)$ pela massa do elétron $\left(m_{e}\right)$.

$$
\omega_{p}=\sqrt{\frac{N_{e} q_{e}^{2}}{\varepsilon_{0} m_{e}}}
$$




\section{Comprimento de Debye dos elétrons}

Se um plasma está sujeito a um campo elétrico externo aplicado, as suas cargas livres ajustam-se de modo que grande parte do plasma seja blindada da ação do campo aplicado.

Para ser considerado plasma, um gás ionizado deve ter um número suficientemente grande de partículas carregadas para blindar-se eletrostaticamente a uma distância menor que outros comprimentos fisicamente relevantes, como por exemplo os comprimentos das dimensões que definem o seu volume.

O comprimento dessa distância seletiva é chamado de comprimento de Debye. Com isso pode-se garantir que, mesmo havendo campos elétricos locais e campos elétricos aplicados externamente, o plasma como um todo é eletricamente neutro. Pois a quantidade de partículas carregadas submetidas a esse campo é suficientemente grande para, ao se redistribuir espacialmente, anular a ação desse campo.

O comprimento de Debye é definido como a raiz quadrada da razão entre a constante dielétrica do vácuo $\left(\varepsilon_{0}\right)$ multiplicada pela constante de Boltzman $\left(k_{B}\right)$ e pela temperatura dos elétrons $\left(T_{e}\right)$, e o número de partículas $\left(N_{0}\right)$ multiplicado pela carga do elétron $\left(q_{e}\right)$ ao quadrado.

$$
\lambda_{D}=\sqrt{\frac{\varepsilon_{0} k_{B} T_{e}}{N_{0} q_{e}^{2}}}
$$

Uma forma de apresentar este e outros conceitos do mundo microscópico pode ser utilizando-se analogias. O uso de analogias para o ensino de física mostra-se como facilitador para a aprendizagem de conceitos em física. Como indicado por JORGE (1990, p. 196):

\footnotetext{
"O aprendizado da física torna-se mais fácil e agradável se o estudo de um fenômeno novo for comparado a um fenômeno semelhante já conhecido. O estudo torna-se mais eficaz se a analogia é feita com um fenômeno encontrado na natureza ou de simples realização na sala de aula."
}

Uma analogia apresentada por INAM e GOLKOWISK (2011, p. 5, tradução nossa) mostra-se bastante útil para a compreensão qualitativa do conceito do comprimento de 
Debye:

"Depois de se adentrar por uma certa distância o interior de uma floresta poderá haver suficiente número de árvores de modo a obstruir a visão de um observador ficando ele ou ela impedido(a) de enxergar a borda da floresta. Entretanto se as árvores estiverem muito afastadas uma das outras e a floresta for muito pequena, o observador ao embrenar-se por entre as árvores, poderá sempre ter à vista a fronteira entre a floresta e o campo, neste caso este grupo de árvores não poderia ser chamado de floresta." 


\section{Capítulo 4 - Aplicação}

A introdução ao estudo da física de plasma no ensino médio proposta envolve a aplicação dos dois produtos, correspondendo o site à parte teórica e a interação com o experimento a parte prática.

A aplicação do primeiro produto educacional, o site, usou o tempo de quatro aulas, ministradas ao longo de duas semanas a uma turma do terceiro ano do ensino médio, com 26 (vinte e seis) alunos com faixa etária de 15 (quinze) a 17 (dezessete) anos, do Colégio Dromos localizado no bairro Sudoeste em Brasília - DF.

A aplicação do segundo produto no ensino médio, interação com o experimento tubo de Crookes, não foi possível pelos motivos apresentados na introdução deste trabalho.

As aulas de física foram dedicadas ao tema de física de plasmas buscando-se também reforçar conhecimentos prévios e naturalmente correlatos, tais como, leis de Newton, processos de eletrização, corrente elétrica, teoria cinética dos gases, ligações moleculares e transição de fases.

A aplicação em sala de aula consistiu em apresentação do conteúdo por meio de aulas expositivas com intervenções de recurso multimídia, fotos, áudios e vídeos, contidos no site desenvolvido específicamente para este fim (http://rodrigoegustavo.wix.com/fisicadeplasmas), e o desenvolvimento de dinâmicas de sala de aula como jogos de perguntas e respostas e dinâmica corporal realizados ao longo das aulas.

Os alunos haviam sido avisados sobre o que aconteceria ao longo das quatro aulas porém sem detalhes sobre o tema ou assunto abordado até o dia da primeira aula.

\section{Aula 1}

Naquele dia os discentes foram informados sobre a aplicação de um teste, o préteste, e que ele seria sem valor para nota ou qualquer outra contribuição para a formação das menções, que ele não teria qualquer tipo de identificação sobre quem o responderia e 
que a sua finalidade seria meramente acadêmica e que, quando da reaplicação, pósteste, o mesmo serviria para avaliar o impacto da inserção de novo conteúdo no ensino médio. Foi solicitado que respondessem às perguntas de modo sincero e procurassem registrar com fidelidade o que estava sendo indagado.

Também no primeiro dia foi indicado, em virtude da apreensão dos alunos sobre a possível cobrança do tema em prova, que aquelas aulas faziam parte de um estudo acadêmico real e aplicado que poderia vir a fazer parte de uma avaliação para inserção de temas comtemporâneos no ensino de física do ensino médio. Prestados os devidos esclarecimentos, foi aplicado o pré teste.

As perguntas usadas tanto no pré quanto no pós teste são as que se seguem:

1 - No contexto da física, você sabe o que é Plasma?

Respostas possíveis: Sim ou Não.

1.1 - Se sim, explique.

Resposta livre.

2 - Você sabe o que há dentro da lâmpada fluorescente?

Respostas possíveis: Sim ou Não.

$2.1-\mathrm{E}$ como ela funciona?

Respostas possíveis: Sim ou Não.

3- Você já ouviu falar de Fusão?

Respostas possíveis: Sim ou Não.

3.1 - Se sim, como ela funciona?

Resposta livre.

4- Você sabe o que é um Tokamak?

Respostas possíveis: Sim ou Não.

5- Você sabe como funciona um acelerador de partículas? 
Respostas possíveis: Sim ou Não.

6- Você sabe o que é um espectrômetro de massa?

Respostas possíveis: Sim ou Não.

7- É importante estudar física?

Respostas possíveis: Sim ou Não.

7.1 - Por que?

Resposta livre.

8- Qual a importância de se estudar eletromagnetismo?

Resposta livre.

9- Você gosta de estudar física?

Respostas possíveis: Sim ou Não.

9.1 - Por que?

Resposta livre.

10- Você pensa em trabalhar em alguma profissão que utilize o estudo da física diariamente?

Respostas possíveis: Sim ou Não.

10.1 - Por que?

Resposta livre.

11 - O que você acha deste trabalho aplicado em sua sala de aula?

Resposta livre.

A aula expositiva seguiu-se à aplicação do teste. Durante a aula foi explicado o que é o estado plasma. Também foi apresentado o conceito formal de plasma: Um gás ionizado que contém elétrons livres em seu interior e é macroscopicamente neutro.

Foram informados os diversos tipos de plasma e onde podemos encontrá-los, usando as imagens disponíveis no site, projetado em uma tela usando-se um projetor 
multimídia. Os plasmas atmosféricos foram abordados mostrando-se imagens de relâmpagos e das auroras boreal e setentrional, informando a diferença entre as duas e o motivo de se encontrar mais imagens da primeira, por ela ocorrer em uma zona do planeta habitada por humanos. Exemplos de plasma no cotidiano foram elencados indicando as lâmpadas fluorescentes e os aparelhos televisores a plasma. Os plasmas espaciais foram relacionados como o material constituinte das estrelas e de algumas regiões do espaço contendo gases ionizados macroscopicamente neutros.

\section{Aula 2}

A segunda aula foi baseada na apresentação de achados históricos, equipamentos e tecnologias vinculados à cronologia de cientistas cujos trabalhos contribuiram para a consolidação da física de plasmas, de 1858 a 1962, indicando as aplicações mais importantes de suas ideias.

Durante esta aula foram realizados rápidos jogos de perguntas e respostas que seguiram um formato dinâmico, permitindo ao alunos serem inquiridos sobre fatos, conceitos, personagens ou descobertas, específicos, logo após a exposição.

A sequência do jogo se deu da seguinte forma: uma pergunta previamente formulada era registrada no quadro e os alunos, em duplas, eram solicitados a respondêlas em seus cadernos. Após um intervalo de dois a três minutos, dependendo da complexidade da questão, o gabarito era revelado e fazia-se o levantamento de quem havia acertado ou não a pergunta.

\section{Aula 3}

A terceira aula tratou-se sobre as transições de fase da matéria, promovendo-se uma revisitação ao conteúdo de termologia e elementos de termodinâmica típicos do segundo ano do ensino médio. Com essa rememorização abordar a transição de fase gás-plasma e temperaturas do plasma representou um complemento ao conhecimento prévio dos alunos.

Apoiado nos conhecimentos sobre eletrização e de termodinâmica dos alunos foram trabalhadas as ideias dos processos de ionização e recombinação, mostrou-se que é possível medir a temperatura em Joules e elétron-volts e apresentas distribuições de 
velocidades.

Repetiu-se a dinâmica de perguntas e respostas para alguns tópicos.

\section{Aula 4}

Na quarta aula houve a realização de uma dinâmica corporal em que cada aluno assumiu ser uma partícula carregada positiva ou negativamente, e puderam simular situações de equilibrio e desequilibrio de distribuição superficial das cargas.

Para tanto a turma foi dividida em dois grupos, grupo um e grupo dois. Os alunos falaram em voz alta "um", "dois", alternadamente a partir do aluno sentado na extrema direita em relação à frente da mesa do professor, colocada no centro da sala próxima ao quadro.

Dessa forma o primeiro aluno falou "um", o segundo falou "dois", o terceiro "um", o quarto "dois", o quinto "um", e assim sucessivamente. De modo que ao final da contagem a turma estava enumerada em dois grupos: o grupo um e o grupo dois. A arrumação das carteiras, em formato de ferradura ou "U", na sala de aula facilitou a enumeração e definição dos grupos.

Em seguida à definição dos grupos foi atribuida carga negativa unitária para cada aluno de um grupo e carga positiva unitária para cada aluno do outro grupo. Daquele momento em diante foi sugerido aos alunos que assumissem a identidade de uma carga elétrica. Este é um momento

O número total de alunos presentes era par de modo que os dois grupos continham a mesma quantidade. Caso fosse ímpar o número de presentes haveria a necessidade, ao menos inicialmente, da participação do professor.

A partir deste momento foi possível realizar uma avaliação pelos alunos a partir de perguntas do professor como:

"A carga total é positiva ou negativa?" 
"A carga está distribuida espacialmente de modo equilibrado ou desequilibrado?"

Em seguida os alunos foram solicitados a levantarem de seus lugares e circularem livremente pela sala e, de tempos em tempos, solicitados a pararem nas posições em que estavam e responderem às perguntas anteriores. Dessa forma podendo experienciar de modo concreto e segundo uma analogia com adaptação imaginativa o que ocorre, grosso modo, em superfícies análogas a de uma superfície de meios gasosos ionizados com espessura de um íons.

Procurou-se reforçar com esta dinâmica corporal a definição de plasma. Ela também pode ser explorada para casos em que é aplicado campo elétrico, campo magnético, constantes ou variáveis, podendo constituir em uma ferramenta rica em turmas que tenha a disposição para este tipo de atividade.

Uma vez reforçado a definição de plasma passou-se a explicação do conceito de comprimento de Debye. Foi apresentada a analogia proposta por INAN, GOLKOWIS indicando que caso os alunos estivessem no Parque da Cidade Sara Kubistek em meio a muitas árvores, em um dos bosques do parque, mesmo vendo muitas árvores ainda não estariam em uma floresta, poderiam escutar os carros passando, ver pessoas andando de bicicleta, fazendo caminhada. Ao passo que caso ao caminharem em alguma trilha pela Floresta Amazônica bastaria afastarem-se por alguns metros para se verem completamente impedidos de ver qualquer traço de civilização, estariam na floresta.

A partir desta analogia e da dinâmica corporal foram desenvolvidos os conceitos de comprimento de Debye e frequencia de plasma. Suas fórmulas foram apresentadas e foi resolvido um exemplo quantitativo da medida deles em uma típica célula de televisor à plasma (INAM, GOLKOWSKI, 2011).

Abordar o processo de emissão de radiação eletromagnética na faixa visível, luz visível, a partir de fontes primárias de plasma, ou seja, emissão de luz por equipamentos cujo objetivo da montagem funcional primordial seja produzir plasma e que a partir desse plasma produzem luz visível, exige que os alunos sejam informados, como foram, sobre a necessidade do uso de substâncias fluorescentes e do processo de fotoemissão.

Para explicar esta parte usou-se o exemplo retirado de INAN, GOLKOWSKI 
(2011, pág. 97, tradução nossa):

"Lâmpadas fluorescentes comuns contém um plasma de baixa pressão chamado de pluma, ou descarga em pluma. O gás no tubo é parcialmente ionizado pela aplicação de uma voltagem nos eletrodos. Os elétrons livres atingem uma pequena porção de átomos de mercúrio, causando a emissão de radiação ultravioleta(UV). Quando a radiação UV atinge a camada de material fluorescente na superfície interna do tubo há emissão de luz branca. A grande maioria das moléculas de gás no tubo permanecem neutras."

Foram apresentadas as figuras 3 e 6 abaixo enquanto se explicava o processo de geração de luz branca na lâmpada fluorescente.

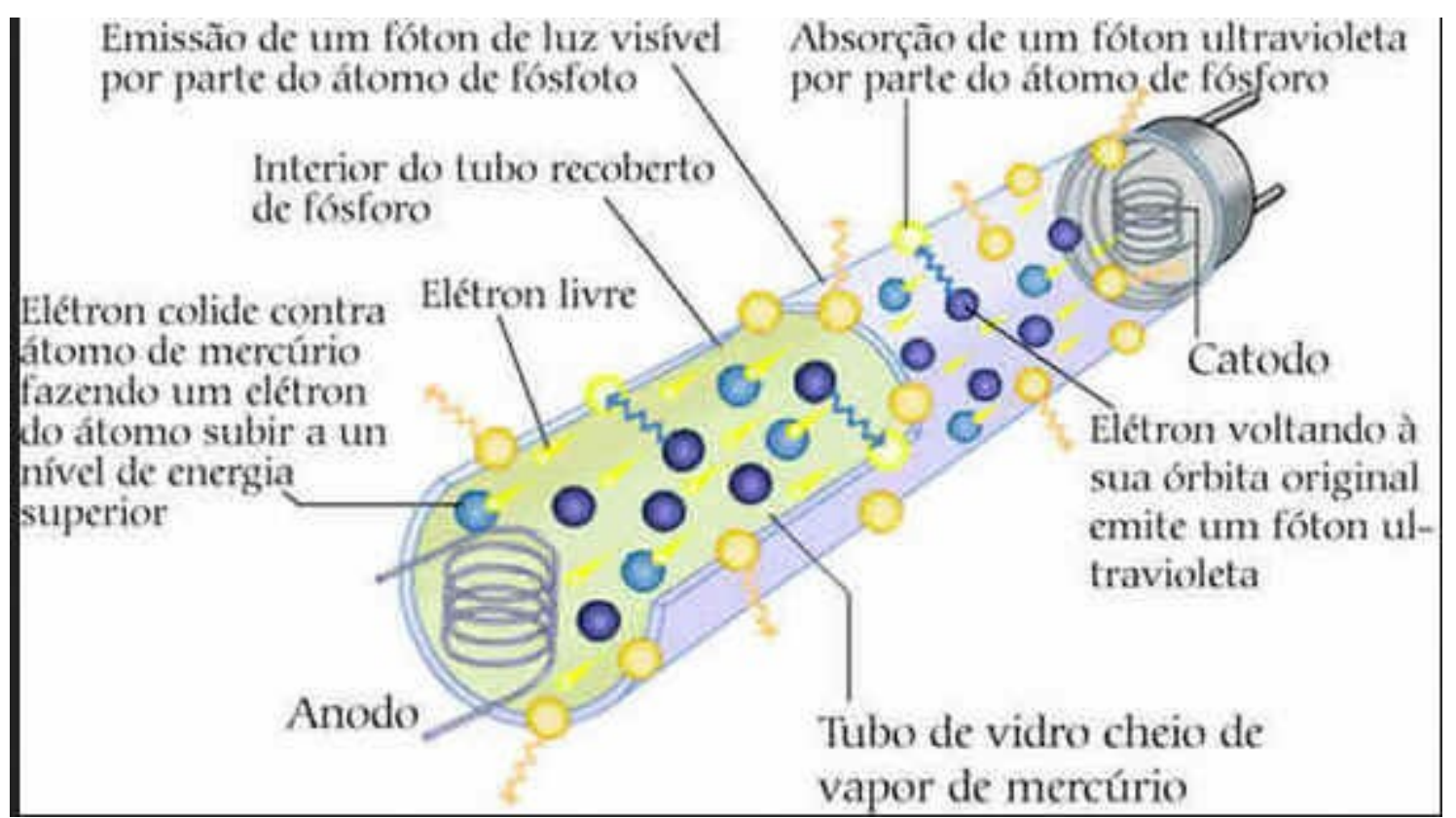

Figura 3: Representação da lâmpada fluorescente. Fonte: Wikipedia

Em uma lâmpada fluorescente, como em qualquer plasma, existem átomos de gás neutros que ao serem atingidos por um elétron podem se ionizar, perdendo um elétron. Esses átomos, e outros pouco ionizados, também podem absorver o elétron incidente em um processo chamado recombinação, levando-o a um estado menos ionizado ou neutro. 


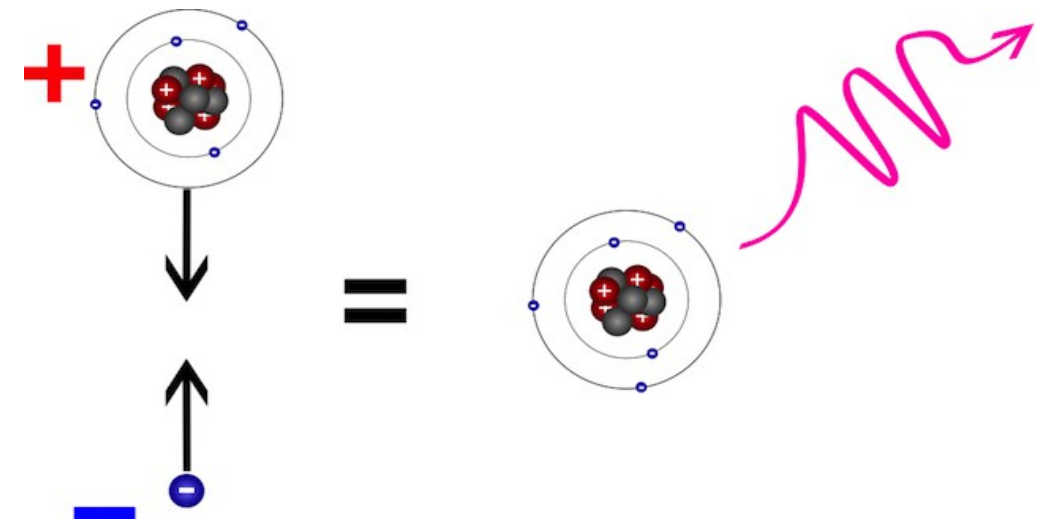

Figura 4: Típico processo de recombinação. Fonte: <http://scied-web.pppl.gov/rgdx/>

Assim, para manter o equilíbrio de sua energia, o átomo emite energia excedente em forma de fóton, ou seja, luz, não necessariamente visível. Para a luz visível, a energia do fóton determina a cor da luz emitida, quanto mais energia ele tivermais próximo do violeta a luz será, quanto menos energia o fóton emitido tiver mais próximo do vermelho será a cor da luz emitida.

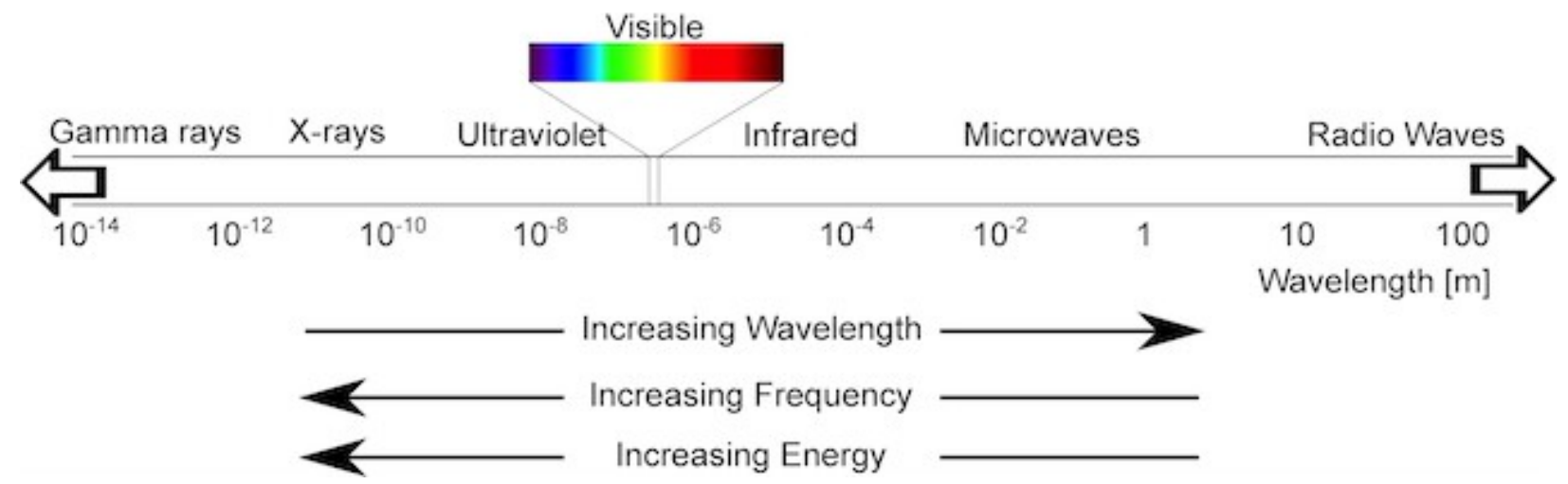

Figura 5: A energia do fóton determina sua cor. Fonte: <http://scied-web.pppl.gov/rgdx/>

Outra possibilidade para emissão de luz é quando o átomo libera energia luminosa como forma de reequilibrar seu nível de energia. Inicialmente o átomo estava com um nível de energia acima do seu nível de equilíbrio. Ele pode ter chegado a este 

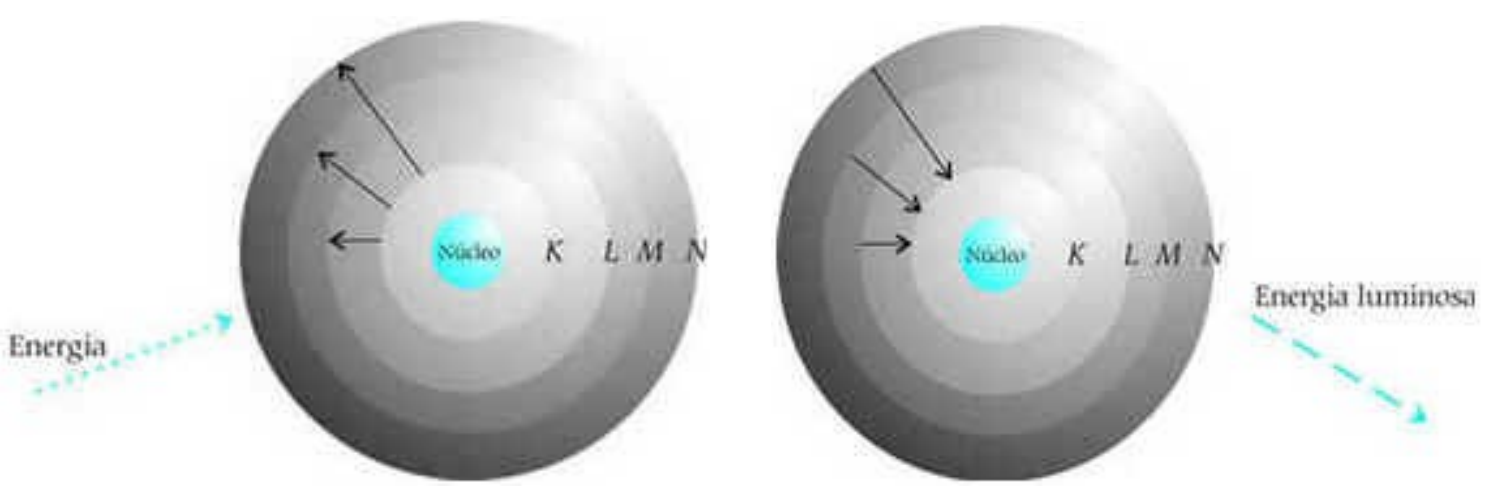

Figura 6: Absorção de energia e emissão de luz Fonte: Wikipedia

estado por ter absorvido um fóton, o que é típico no processo de fluorescência quando o átomo absorve um fóton ultravioleta e emite outro na faixa da luz visível, ou por resultado de uma colisão de um elétron cuja energia não foi suficiente para arrancar um de seus elétron mas deixou-o com um nível de energia acima do seu nível de equilíbrio.

Em seguida passou-se ao exemplo do cálculo do comprimento de Debye e da frequência de plasma para uma típica célula de um monitor ou TV a plasma. Nestes equipamentos "(...) cada pixel contêm três células de plasma, cada uma com uma cor fundamental, azul, verde ou vermelho(...)" (INAN, GOLKOWSKI, 2011), como mostrado na Figura 5.

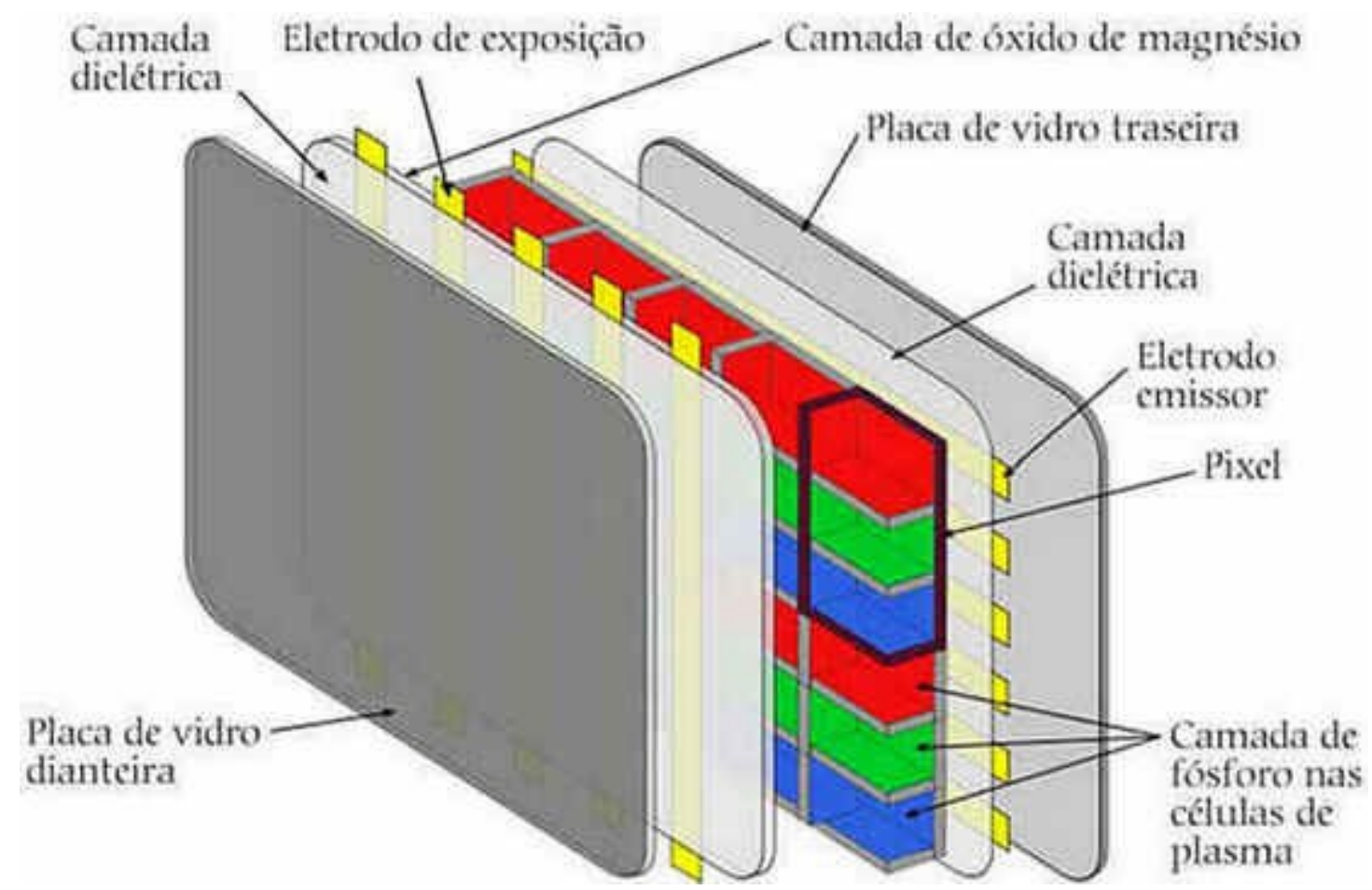

Figura 7: Típica célula de monitor a plasma. Fonte: Wikipedia 


\section{O exemplo aplicado foi:}

"Calcule o comprimento de Debye e a frequência de plasma para o plasma contido numa célula de uma típica TV a plasma com os seguintes parâmetros: $\quad \mathrm{N}_{\mathrm{e}}=10^{19} \mathrm{~m}^{-3}, \mathrm{k}_{\mathrm{B}} \mathrm{T}=1 \mathrm{eV}$. A célula tem dimensões da ordem de $0,1 \mathrm{~mm}$ e o plasma é gerado usando-se um sinal com diferença de potencial de $250 \mathrm{~V}$ e frequencia de $100 \mathrm{kHz} . "$ (INAN, GOLKOWSKI, 2011, pág. 15, tradução nossa).

Usando-se para tanto as respectivas fórmulas indicadas à página 40.

Ao final da quarta aula foi aplicado o pós-teste.

De um modo geral, as aulas transcorreram sem surpresas e contaram com a participação entusiasmada dos alunos em diversos momentos. Tópicos com uma vocação multidisciplinar mais acentuada suscitaram o maior número de interferências positivas, contributivas, principalmente os envolvendo temas recorrentes na grande mídia como fontes energéticas, bosóns de Higgs - recentemente houve a divulgação da descoberta de uma nova partícula com características compatíveis às previstas para o bóson de Higgs (NOTICIAS, 2015), em experimentos realizados no Laboratório Large Hadrons Collider (LHC) do Centro Europeu de Pesquisas Nucleares (CERN) - viagens espaciais, com os alunos interessados em maiores detalhes e compartilhando conhecimentos e experiências. Os alunos foram incentivados a explorar em outras fontes material sobre física de plasma e sobre tópicos que despertaram maior interesse. 


\section{Capítulo 5 - Resultados da Aplicação}

O questionário-teste aplicado antes e após a realização das quatro aulas sobre física de plasma, o produto um, aqui referidos como pré-teste e pós-teste, teve o objetivo de verificar a familiaridade auto-declarada dos alunos com o assunto - perguntas 1 a 5 , a disposição declarada deles para o estudo de física e de eletromagnetismo - perguntas 6 a 8.1, e por fim a opinião deles em relação à realização da atividade - pergunta 9.

A aplicação em sala de aula do produto 1 teve boa recepção por parte dos alunos como se pode verificar com a análise das respostas, contidas no Apêncice $A$, à pergunta 9 - "O que você acha deste trabalho aplicado em sua sala de aula?". Mesmo antes das atividades, dezoito dos vinte e um alunos presentes na primeira aula emitiram opiniões positivas acerca da realização da atividade, havendo duas opiniões contrarias e uma neutra. Após a realização das mesmas as opiniões positivas foram praticamente unânimes, uma das respostas está ilegível.

Uma verificação possível com as informações coletadas pelos questionários se dá a partir dos resultado indicados no gráfico 1 , de que as aula não alteraram significativamente a postura dos alunos em gostar ou não de estudar física, pergunta 7 .

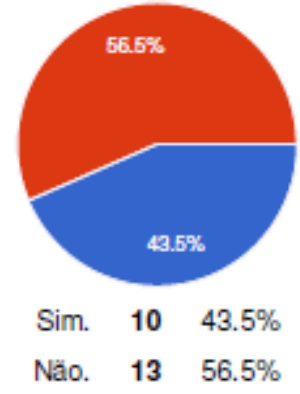

Pré-teste

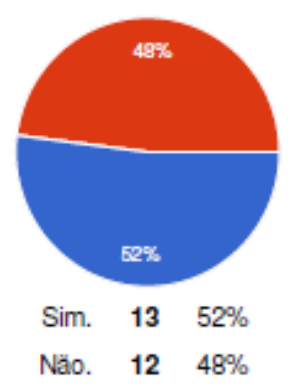

Pós-teste

Gráfico 1: Em azul, "sim", em vermelho, "não": respostas à pergunta 7 - "Você gosta de estudar física?", antes e após as aulas. Fonte: do autor.

Nos resultados do pré-teste contidos no Apêncice A é marcante a associação ao gostar ou não gostar de física, pergunta 7.1, com a matemática, fórmulas e números, havendo seis respostas com o uso de alguma dessa palavras como justificativa, sendo que em três delas esse é o motivo para gostar e em outras três o motivo para não gostar. Com significado próximo a estas também foi associado o gostar ou não gostar de física ao fato de ser uma disciplina da área de exatas, existindo uma resposta como justificativa para gostar e duas como justificativa para não gostar. Do mesmo modo relacionou-se em 
uma resposta o gosto ou preferência pela área de humanas como justificativa para não gostar de física. Assim também se posicionou quem usou a palavra difícil ou a expressão "não entendo", com cinco respostas. Outras quatro respostas relacionaram o gostar com entender fenômenos ou funcionamento das coisas. Duas respostas chamaram a atenção por relacionar o gostar com o futuro do estudante sendo que em uma há menção que a profissão pretendida usa muita física. Por fim foram registradas duas respostas sem relação com a pergunta elaborada. O padrão das respostas ao pós-teste seguem um padrão semelhante destacando-se justificativas melhor elaboradas para o gostar de física, como, "Porque nos permite entender fenômenos sutis do nosso mundo", "Para entender o que acontece no cotidiano", ou "Pois é interessante saber mais sobre o universo", ou ainda "É interessante ver as relações que ocorrem nas materias", dentre outras.

Foi bastante significativo, dentre os resultados obtidos antes e após as aulas, a alteração no número de auto declarações que indicam saber o que é plasma no contexto da física, pergunta 1. Após as aulas o percentual de alunos que declararam saber o que é plasma foi de oitenta e quatro por cento contra aproximadamente nove por cento antes das aulas, como mostra o gráfico 2. Ocorreu assim praticamente uma inversão no número de declarações entre saber e não saber, o que é plasma, comparando as declarações de antes e após a aula.

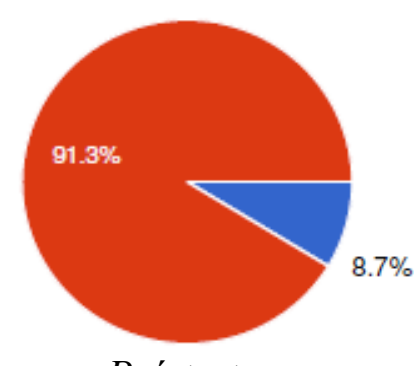

Pré-teste

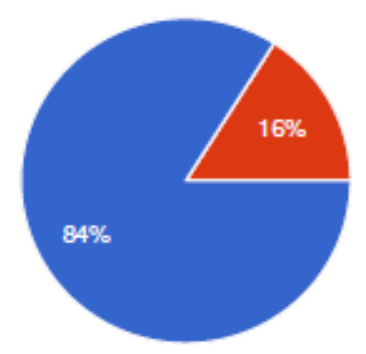

Pós-teste

Gráfico 2: Em azul, "sim", em vermelho, "não": respostas à pergunta 1 - "No contexto da física, você sabe o que é plasma?", antes e após as aulas. Fonte: do autor.

Foi significativo o aumento das tentativas de explicação do que os alunos entendem como plasma, pergunta 1.1, complemento da pergunta 1 , como se pode verificar no Apêndice1.

Antes das aulas houve três respostas sendo uma delas desconsiderável, por não ter sido formada uma sentença com algum sentido. Das duas outras uma está correta, indicando que o aluno sabia de que se tratava de um estado físico da matéria, a outra tentou indicar que seria um estado físico mas não conseguiu precisar suas características. 
Após as aulas, no entanto, o número de tentativas de explicar o que é plasma aumentou para vinte e duas sendo que quatorze usaram, ou tentaram usar, a definição formal, cinco delas usaram representações do estado físico da matéria ou onde ele é encontrado, uma resposta tentou explicar usando termos com outro significado e duas não tentaram explicar.

Em relação a saber o que há há no interior de uma lâmpada fluorescente, pergunta 2, a distribuição passou de aproximadamente metade da turma saber o que há no interior de uma lâmpada fluorescente para praticamente todos declararem saber, como se pode observar no gráfico 3 .

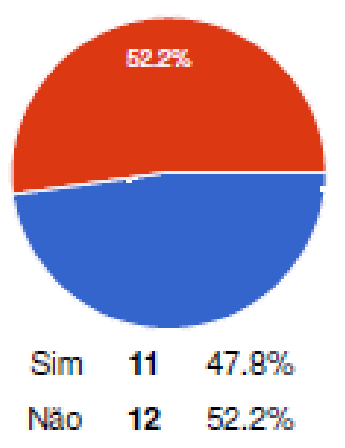

Pré-teste

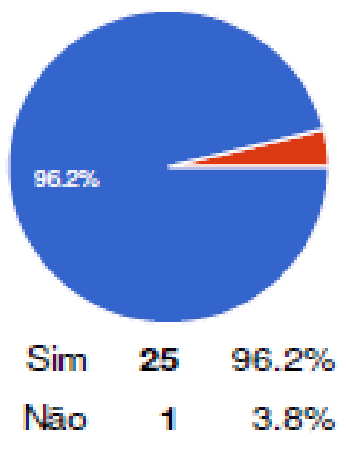

Pós-teste

Gráfico 3: Em azul, "sim", em vermelho, "não": Quantidade de Alunos que afirmam saber o que há no interior de uma lâmpada fluorescente - pergunta 2. Fonte: do autor.

O mesmo incremento de declarações afimativas não é observado para os que declararam saber como a lâmpada fluorescente funciona, pergunta 2.1. Inicialmente trinta por cento dos alunos indicaram saber como a lâmpada fluorescente funciona e após as aulas aproximadamente oitenta e um por cento o fizeram como mostra o gráfico 4.

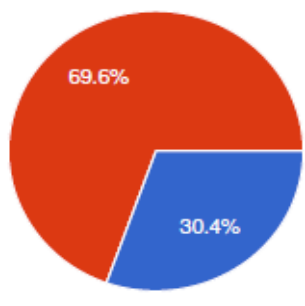

Sim. $730.4 \%$

Năo. $16 \quad 69.6 \%$

Pré-teste

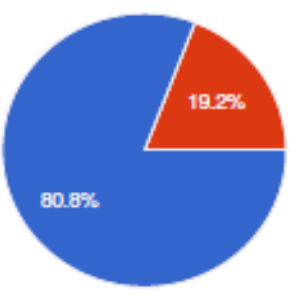

Sim. $21 \quad 80.8 \%$

Nāo. $519.2 \%$

Pós-teste

Gráfico 4: Em azul, "sim", em vermelho, "não": Quantidade de alunos que afirmam, sim, saber, ou não, como funciona uma lâmpada fluorescente - pergunta 2.1. Fonte: do autor. 
Curioso notar que ao serem questionados se já haviam ouvido falar de fusão termonuclear, pergunta 3, mesmo após terem participado das aulas, aproximadamente vinte e sete por cento dos alunos afirmaram não terem ouvido falar sobre isto. De todo modo mais do que dobrou o número de alunos que afirmam já terem ouvido falar de fusão termonuclear como mostra o gráfico 5.

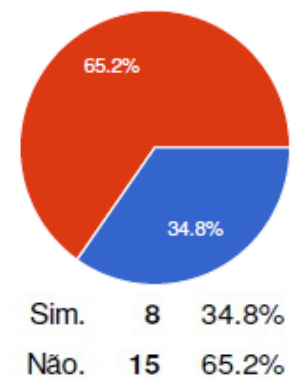

Pré-teste

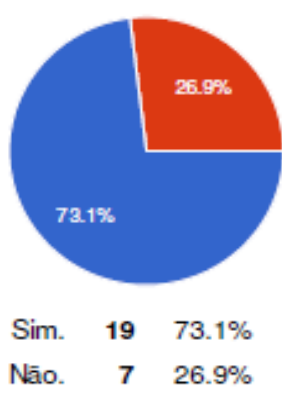

Pós-teste

Gráfico 5: Em azul, "sim", em vermelho, "não": Quantidade de alunos que afirmam, sim ou não, terem ouvido falar em fusão termonuclear - pergunta 3. Fonte: do autor.

A disposição em explicar como a fusão nuclear funciona aumentou na mesma proporção dos que declararam já terem ouvido falar dela, como se depreende de análise às respostas contidas no Apêncice $A$. Sendo que inicialmente dois alunos indicaram de alguma forma em suas explicações como ela funciona, outros dois tentaram sem sucesso e três redigiram respostas que não explicavam o funcionamento. Após as aula o número de respostas que tentaram explicar de alguma forma o funcionamento da fusão termonuclear passou para dezesseis e dentre estas cinco concatenaram a ideia de fusão usando os termos e conceitos de modo ao menos minimamente adequados, sete tentaram usar os termos corretos porém sem alcançar a uma ideia razoavel e estavam no

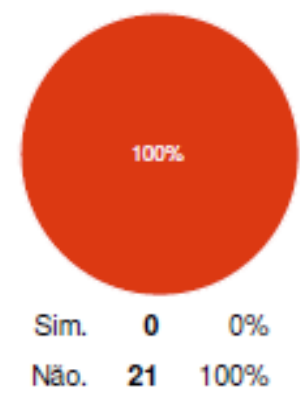

Pré-teste

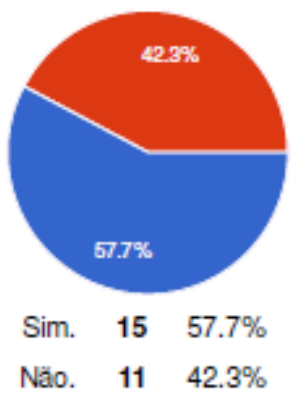

Pós-teste

Gráfico 6: Em azul, "sim", em vermelho, "não": Quantidade de alunos que afirmam, sim ou não, saberem o que é um Tokamak - pergunta 4. Fonte: do autor. 
rumo certo, quatro tentaram responder usando termos ou conceitos correlacionados com a definição porém de forma parcial ou incompleta, e finalmente em três das respostas não houve tentativa de explicar a fusão.

Foi considerável o aumento do número de alunos que afirmaram saber o que é um Tokamak, pergunta 4. Após a aula houve um incremento de praticamente sessenta por cento destes, gráfico 6 . O que não aconteceu para a pergunta 5 , que inquiriu sobre eles conhecerem um outro típico equipamento produtor de plasma, o tubo de raios catódicos. Como se pode verificar no gráfico 7 o incremento de respostas afirmativas a esta questão foi de aproximadamente vinte e cinco por cento.

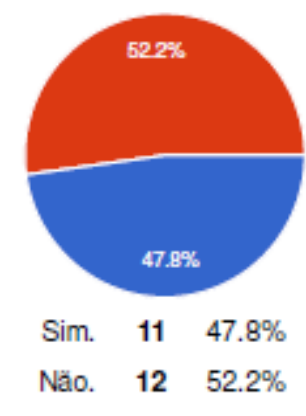

Pré-teste

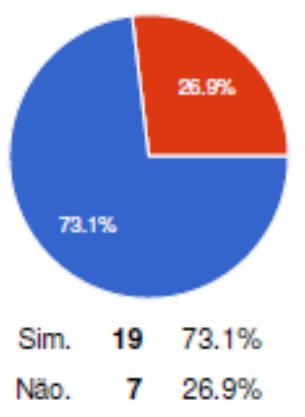

Pós-teste

Gráfico 7: Em azul, "sim", em vermelho, "não": Quantidade de alunos que afirmam, sim ou não, saberem o que é um tubo de raios catódicos - pergunta 5. Fonte: do autor.

A disposição em responder à pergunta 6 - por que é importante estudar eletromagnetismo, também aumentou, observando-se os registros contidos no Apêncice A. Antes das aulas sessenta por cento dos alunos responderam à pergunta e após as aulas praticamente cem por cento dos alunos redigiram alguma resposta. Importante notar que tanto no pré-teste quanto no pós-teste a resposta mais frequente com nove e quinze ocorrências, respectivamente, contém alguma palavra com o sentido de entender, compreender, estudar, funcionar ou envolve alguma aplicação do conhecimento de eletromagnetismo. Tanto antes quanto após as aulas dois alunos afirmaram que a importância de se estudar eletromagnetismo está vinculada a cobrança em provas e também dois alunos não souberam responder. Houve ainda o relacionamento da importância com fenômenos naturais tendo ocorrido em uma resposta do pré-teste e em três do pós-teste. Pode-se notar ainda no pós-teste a existência de três respostas evazivas ou não-resposta pois não fazem sentido.

Sobre os estudantes pensarem em trabalhar em alguma profissão que utilize o 
estudo da física diariamente, pergunta 8, não houve praticamente variação significativa no padrão de respostas, a grande maioria, cerca de oitenta e cinco por cento dos estudantes declaram que não pensam em trabalhar com alguma profissão que utilize o estudo da física diariamente tanto no pré quanto no pós-teste, gráfico 8. De onde se pode inferir que este tipo de atividade não alcança alterar suas pretenções profissionais.
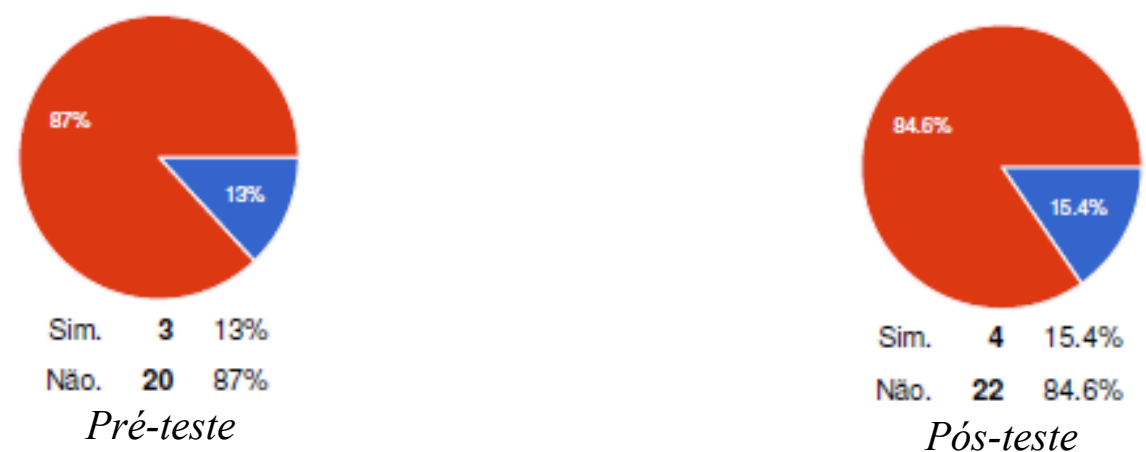

Gráfico 8: Em azul, "sim", em vermelho, "não": Quantidade de alunos que afirmam, sim ou não, pensarem em trabalhar em alguma profissão que utilize o estudo da física diariamente - pergunta 8. Fonte: do autor.

A tabela a seguir mostra os resultados gerais das perguntas objetivas do questionário.

\begin{tabular}{|l|c|c|c|c|}
\hline \multicolumn{1}{|c|}{ Perguntas } & \multicolumn{2}{c|}{ Pré-teste } & \multicolumn{2}{c|}{ Pós-teste } \\
\cline { 2 - 5 } & $\operatorname{Sim}(\%)$ & Não (\%) & Sim (\%) & Não (\%) \\
\hline 1 - No contexto da física, você sabe o que é & & & & \\
\hline Plasma? & 8,7 & 91,3 & 84 & 16 \\
\hline $\begin{array}{l}\text { 2-Você sabe o que há dentro da lâmpada } \\
\text { fluorescente? }\end{array}$ & 47,8 & 52,2 & 96,2 & 3,8 \\
\hline 2.1 - E sabe como ela funciona? & 30,4 & 69,6 & 80,8 & 19,2 \\
\hline 3- Você já ouviu falar de Fusão termonuclear? & 34,8 & 65,2 & 73,1 & 26,9 \\
\hline 4- Você sabe o que é um Tokamak? & 0 & 100 & 57,7 & 42,3 \\
\hline 5- Você sabe o que é um tubo de raios catódicos? & 47,8 & 52,2 & 73,1 & 26,9 \\
\hline 7- Você gosta de estudar física? & 43,5 & 56,5 & 52 & 48 \\
\hline $\begin{array}{l}\text { 8- Você pensa em trabalhar em alguma profissão } \\
\text { que utilize o estudo da física diariamente? }\end{array}$ & 13 & 87 & 15,4 & 84,6 \\
\hline
\end{tabular}

Tabela 2: Compilação dos resultados gerais dos testes. Fonte: do autor.

\section{Contribuições e possíveis melhorias}

Ao longo das aulas verificou-se a possibilidade de que alguns tópicos de física moderna relacionados ao entendimento do estado plasma, como o espectro de emissão luminosa pelos materiais, serem de alguma forma desenvolvidos de forma correlata. Esses tópicos também podem ser explorados com maior nível de detalhamento caso identifique-se interesse dos alunos e disponibilidade de aulas. Eles podem ser inseridos no planejamento anual como revisão e/ou atividade multidisciplinar, nesse último caso 
envolvendo os professores de química. São elas:

- Melhor detalhamento atômico molecular da reação de fusão nuclear;

- Mais extenso detalhamento da transição de camadas eletrônicas atômicas para emissão de fótons visíveis ou não, seja pelo plasma seja por substâncias fosforescentes e fluorescentes;

- Ampliação do detalhamento sobre as diferentes composições químicas das substâncias fosforescentes e fluorescentes e o aprimoramento da sua obtenção, aplicação e o aumento da variedade de substâncias identificadas para esta aplicação. 


\section{Capítulo 6 - Experimento}

O desenvolvimento das ideias de eletricidade e magnetismo, passando pela identificação de suas naturezas distintas, ocorreu de forma incremental ao longo dos séculos XVII a XIX, partindo de atributos creditados ao material de corpos eletrizáveis, avançando para a ideia de fluido e por fim concebendo a existência de uma partícula representante da unidade de carga elétrica, o elétron. O que por sua vez conduziu a um modelo aceito como consistente para o átomo e às tecnologias que revolucionariam a Humanidade no século XX.

Nesse contexto, o desenvolvimento de um aparato experimental e o incremento em suas funcionalidades foi de crucial importância para a física e para a química do século XX.

Um tubo de vidro com baixa pressão interna $(0,01 \%$ atmosfera), construído por Geissler e incrementado com eletrodos internos por seu amigo Plücker, ficou conhecido como tubo de raios catódicos e uma configuração diferenciada dele permitiu a Crookes determinar a relação carga / massa dos elementos portadores de cargas elétricas.

No entanto, muitos fenômenos de natureza eletromagnética envolvendo gases restavam ou parcialmente compreendidos ou incompreendidos até o início do século $X X$.

A fim de isolar alguns desse fenômenos e tratá-los com a devida diferenciação em 1928 Langmuir usa o termo plasma para referir-se aos gases luminescentes, ionizados e contendo elétrons livres, tipicamente observáveis nos tubos de raios catódicos, usando para tanto suas exímias habilidades experimentais.

A atividade experimental tem reconhecida importância por inúmeros pesquisadores e professores de Ciências, como meio eficaz para o ensinoaprendizagem. As pesquisas atuais têm procurado caracterizá-la por propósitos, abordagens e em seus diferentes enfoques (Araujo \& Abib, 2003). Do ponto de vista educacional, presume-se que o uso da experimentação para o ensino de Física possa, além de trazer respostas aos questionamentos feitos pelos estudantes sobre a validade ou limitações de modelos físicos, gerar novas questões, influenciando diretamente o 
ensino de ciências e, no limite, estimular a produção científica.

No tocante à Ciência, Tecnologia e Sociedade (CTS), a construção de aparatos experimentais para a comprovação teórica pode gerar soluções de desenvolvimento menos agressivas ao planeta, questão determinante nos rumos da qualidade de vida de toda uma população. Neste contexto, percebe-se que para compartilhar conceitos e significados em ciências, ampliar os saberes nos âmbitos educacionais e tecnológicos, independente das abordagens experimentais usadas, estará presente o método experimental como indicado por ZARATINI, NEVES e SILVA (2013).

Nesse sentido, o uso de experimentos tem sido estudado como ferramenta de ensino de sucesso tanto em ambientes formais quanto em ambientes informais como mostrado nos estudos de GASPAR e MONTEIRO (2005), de D'ANGELO e ZEMP (2014) e de URIAS e ASSIS (2009).

O estudo de GASPAR e MONTEIRO (2005) mostra o efetivo aumento na pré-disposição para ciências a partir da interação com experimentos demonstrativos. $\mathrm{O}$ que tem sido verificado sistematicamente pelo autor em sala de aula quando da realização de experimentos como os propostos por LIMA, VENCESLAU e NUNES (2002) e por LIMA, VENCESLAU e BRASIL (2014).

A intenção é que esse seja um experimento demonstrativo interativo portável, de física de plasma, semelhante a um tubo de Crookes. Ele foi desenvolvido inteiramente dentro desse projeto de mestrado e espera-se que possa ser usado em conjunto com 0 material disponivel no site (http://rodrigoegustavo.wix.com/fisicadeplasmas).

Para que o equipamento possa promover a interação experimental dos alunos em sala de aula há que atender alguns pré-requisitos, e também manter a possibilidade desenvolvimento de estudos também em nível de graduação, iniciação científica e ainda atender a outros projetos de futuros discentes do MNPEF.

Assim desenvolveu-se um equipamento portável e ao mesmo tempo que permitisse ajustes de algumas variáveis, para que permita a efetiva interação com os alunos, como por exemplo o uso de diferentes gases, o ajuste de pressão e potencial elétrico, o acoplamento de sonda de Langmuir, a submissão a campo magnético variável ao longo do eixo do tubo, entre outros.

A escolha do tubo de Crookes, ou tubo de descargas em gases a baixa pressão, referido neste trabalho com o tubo de descargas, se deu por vários motivos, dentre eles: a expertise do orientador em montagens anteriores na Universidade de São 
Paulo (USP), na Universidade Estadual Paulista (UNESP) de Guaratingueta, e na Universidade Católica de Brasília (UCB). Também por ser este equipamento poder ser considerado o avô das lâmpadas fluorescentes, o que possibilida o resgate do desenvolvimento tecnológico uma vez que seu processo de montagem retoma um pouco a história do desenvolvimento técnico e tecnológico na busca por controlar e isolar o processo de ionização. Este aparato tem, portanto, forte aderência aos preceitos do PNE, $\mathrm{PCN}$ e PCN+ .

O uso de tubos de descargas nas mais diversas investigações científicas gerou inúmeras consequencias marcantes para a ciência e para a humanidade, dentre elas:

- $\quad$ A indicação em 1893 de que os elétrons são muito menores que o átomo por Philipp Lenard (1862-1947) rendendo-lhe um prêmio Nobel em 1905 (NOBELPRIZE.ORG);

- $\quad$ A descoberta do raio-x em 1895 por Wilhem Conrad Röntgen (18451923) que rendeu-lhe um premio Nobel em 1901 (NOBELPRIZE.ORG);

- $\quad$ A descoberta da relação massa-carga do elétron $(\mathrm{m} / \mathrm{q})$ em 1897 por J. J. Thomson (THOMSON, 1897), tendo ele recebido um premio Nobel em 1906 pelos estudos em condução da eletricidade pelos gases (NOBELPRIZE.ORG);

- $\quad$ O desenvolvimento de iluminação de baixo consumo que tornou-se comercialmente viável a partir da década de 1930 (GOEKING, 2009);

- $\quad$ Crookes aponta, em 1879, a possibilidade de se estar lidando com o $4^{\circ}$ estado da matéria (COOKES, 1879).

\section{O tubo de Crookes}

Características do tubo de descargas:

"Um tubo de descarga é um tubo (geralmente de vidro), com dois (ou mais) eletrodos inseridos nele, que foi parcialmente evacuado, mantendo-se uma quantidade residual de um gás ou mistura de gases, de modo que a pressão final no interior do tubo seja menor do que a pressão atmosférica. Esses tubos têm a propriedade de, com o aumento da tensão elétrica aplicada aos eletrodos, atingir uma tensão 
chamada tensão de ruptura dielétrica, ou apenas tensão de ruptura, em que qualquer ionização localizada do gás vai iniciar um processo de avalanche que se espalha através o tubo." (GAS, 2013, tradução nossa com adaptações).

A Curva de Paschen para tubos de descarga indica a voltagem versus a pressão do gás e a distância entre os eletrodos a partir dos quais ocorre a avalanche iônica, detalhada mais adiante neste texto.

Gases compostos por distintos elementos químicos apresentam comportamentos diferentes como pode-se ver nos gráficos abaixo, seguido de uma explicação de sua interpretação.

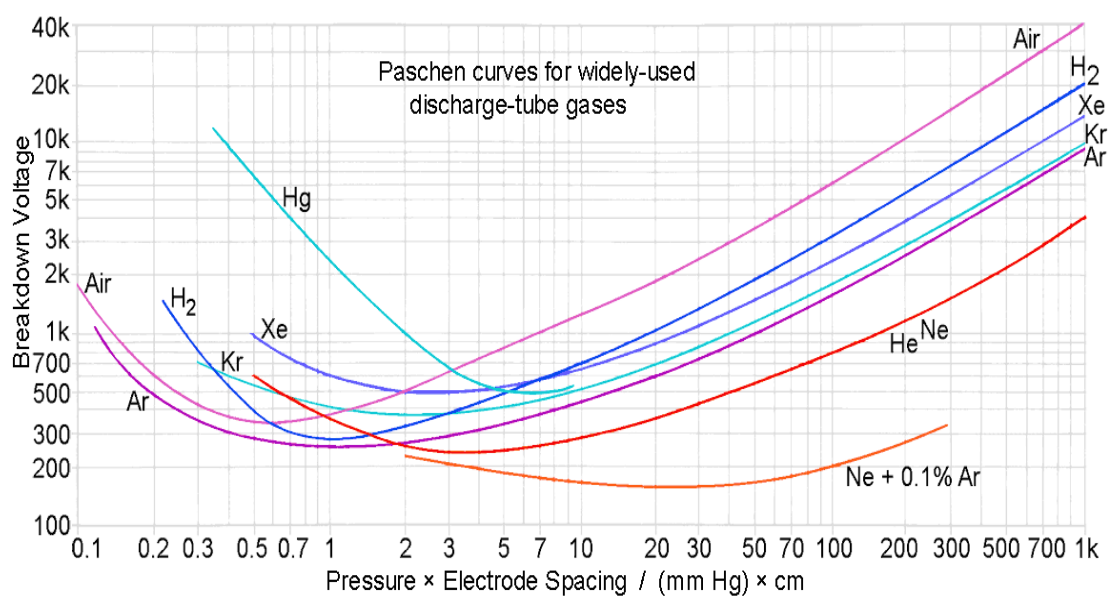

Figura 8: Curvas de Pasche para tubos de descarga mais usados. Fonte: Wittenberg (1962) apud GAS.

"O valor da tensão no qual ocorre a ruptura dielétrica depende da composição e da pressão da mistura gasosa e ainda da intensidade do campo elétrico aplicado, de acordo com uma relação conhecida como lei de Paschen. Surpreendentemente, a tensão de ruptura não simplesmente aumenta com o aumento do espaçamento dos eletrodos, mas segue uma 'curva de banheira', isto é, existe um intervalo de espaçamentos para as quais a tensão de ruptura, na verdade, aumenta à medida que os eletrodos ficam mais próximos. A razão para isso é que a ruptura depende da probabilidade de colisões entre os eléctros e os átomos, e há um regime em que encurtar a distância entre os eletrodos faz com que a probabilidade de colisão seja muito baixa para dar início ao processo de avalanche. As curvas de Paschen para alguns 
dos gases de descarga de tubos comuns são mostradas acima. Para estas curvas deve-se assumir eletrodos planos paralelos.

Para dar uma idéia de como interpretar o gráfico, note que a pressão atmosférica é de $760 \mathrm{~mm} \mathrm{Hg}$ (760 Torr). Por conseguinte, uma linha vertical correspondente a 76, na pressão vs. eixo da distância, dá a tensão de ruptura de um gás entre um par de eletrodos planos separados por $1 \mathrm{~mm}$. Para o ar, isso dá uma tensão de ruptura de cerca de 5 kV DC (3,5 kV RMS AC). Assim, a curva obtida para o ar pode (por exemplo) ser usada para ajustar a voltagem de capacitores variáveis a ar; apesar de uma margem de segurança ser normalmente incluída em virtude da rugosidade da superfície e de bordos afiados, o que pode reduzir consideravelmente a tensão de ruptura.

Eletrodos, aliás, não são essenciais para obtenção de descargas elétricas em gás. Qualquer método que produz um campo elétrico forte o suficiente, com ou sem eletrodos, também fará com que o gás (ou regiões aí contidas) brilhem; e é por isso que tubos de descarga comerciais [lâmpadas fluorescentes] acendem quando colocados perto de antenas ressonantes de rádio e bobinas.

Uma vez que uma descarga luminescente entre os eletrodos inicia-se uma corrente elétrica de baixa resistência é formada, e esta corrente passa a sustentar a descarga. Assim, a resistência do tubo permanece baixa e o brilho vai continuar até que a corrente caia abaixo de um valor chamado de 'ponto de extinção'. A tensão no ponto de extinção é geralmente consideravelmente menor do que a tensão de ruptura, ou seja, a descarga é difícil para começar, porém, em seguida, difícil de parar uma vez iniciado." (GAS, 2013, tradução nossa com adaptações).

A avalanche iônica ou Avalanche de Townsend acontece quando:

"Os elétrons ejetados da superfície de um catodo, quando uma diferença de potencial suficiente é aplicada ao catodo e ao anodo, são acelerados em direção ao anodo. A energia cinética dos elétrons pode ser tão alta que ao colidirem-se com moléculas neutras pode ionizá-las, no caso de colisão elástica, ou podem tornar-se mais energéticos (colisão inelástica) e passar a um nível maior de energia vibracional. Quando, após uma colisão inelástica, um elétron ganha mais energia 
do que a necessária para a ionização das moléculas do gás, ele passa a ter energia suficiente para arrancar um elétron de uma molécula inicialmente neutra, tornando-a um íon positivo. O elétron que foi ejetado passará, junto com o elétron que o arrancou da molécula inicialmente neutra, a repetir o processo de ionização em outras moléculas até então neutras. Como as moléculas são muito mais pesadas que os elétrons, suas contribuições no proceso de ionização são consideradas nulas, sendo tratadas, neste caso, como estacionárias. Os elétrons, ao contrário das moléculas, movem-se muito rápido sob influêcia do campo elétrico aplicado e assim continuam colidindo e ejetando outros elétrons das moléculas do gás inicialmente neutro dando continuidade ao processo de ionização. Uma avalanche de elétrons finalmente atinge $o$ anodo como mostrado na figura a seguir." (GASEOUS DIELETRICS, 2015, tradução nossa com adaptações)

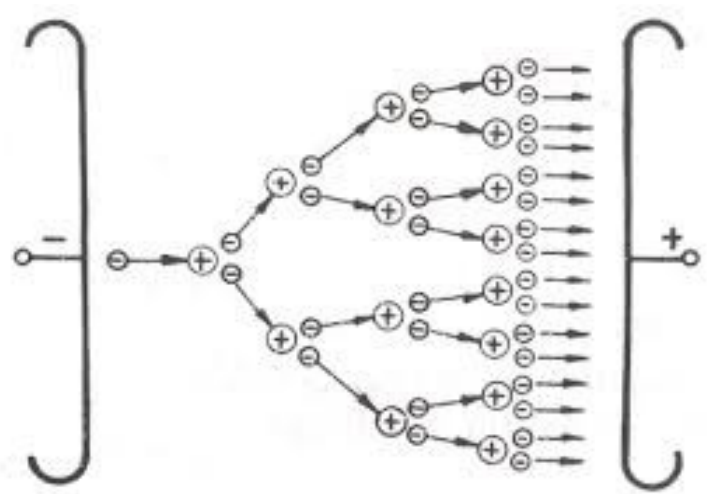

Figura 9: Avalanche de Townsend. Fonte: GASEOUS DIELETRICS.

\section{Estrutura Básica da descarga luminescente}

Em um tubo de Crookes distintos regimes de descargas provocarão diferentes efeitos visuais ao observador, o que inclui dizer que nem toda descarga provocará luminescência, embora exista a descarga.

Para que haja luminescência em um tubo de descargas algumas condições devem ser atendidas, e a relação entre a tensão nominal aplicada aos eletrodos e a corrente elétrica que percorre o gás no interior do tubo será determinante para o tipo de luminosidade emitida pelo tubo. 
"A característica da relação corrente e tensão de uma descarga luminescente é altamente não linear, como são muitos fenômeno de plasma, e a física linear ordinária não pode ser aplicada para explicar a sua estrutura. Para uma descarga luminescente básica gerada a partir de corrente contínua, três regiões principais podem ser distinguidas umas das outras: descarga escura, descarga luminescente e descarga de arco.

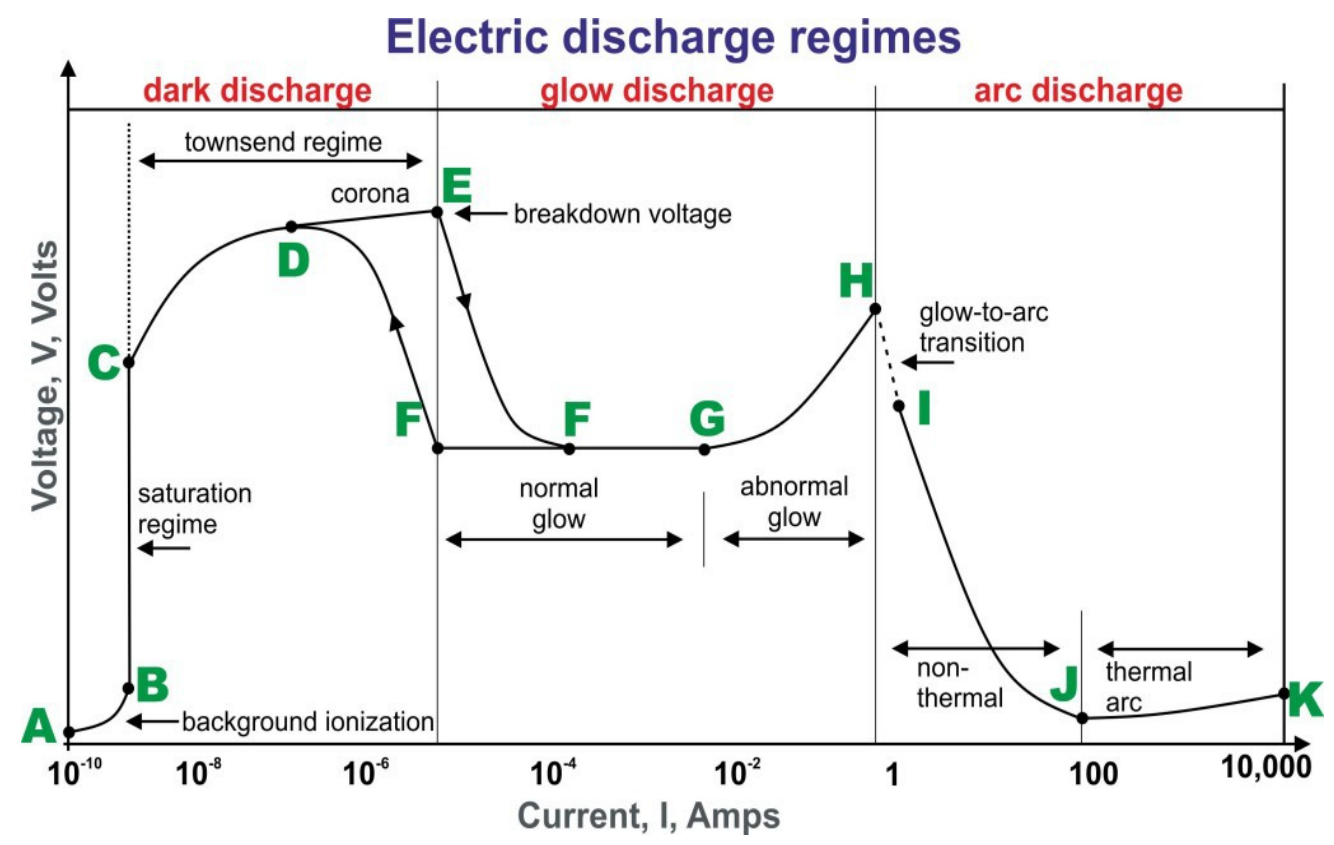

Figura 10: Regime das descargas elétricas. Imagem de lan Tresman compartilhada sob a licensa Creative Commons Attribution 3.0. Imagem sem alterações.

A figura acima é uma representação típica da diferença de potencial pela corrente ( $\mathrm{V} / \mathrm{i})$ de uma descarga luminosa. As principais características da descarga, tais como a tensão de ruptura, a corrente e a tensão características à estrutura da descarga dependem da geometria e do material dos eletrodos, do gás utilizado e da pressão.

Descarga escura (modo de corrente escura)

O comportamento entre $A$ e $E$ da tensão e corrente características é denominada descarga escura, porque, exceto para a descarga corona e para a descarga de colapso, ela permanece invisível ao olho humano. A - B: Durante a fase de ionização de fundo o campo elétrico aplicado ao longo do eixo do tubo varre os íons e os elétrons que existem a uma quantidade constante e mensurável no ar à pressão atmosférica. Estes íons e elétrons migram para o catodo e anodo, respectivamente, produzindo uma corrente elétrica fraca. $\mathrm{O}$ aumento da tensão varre 
uma fração crescente destes íons e elétrons.

B - C: Se a tensão entre os eletrodos é aumentada o suficiente, eventualmente, todos os elétrons e íons disponíveis são varridos, e a corrente é dita saturada. Na região de saturação, a corrente permanece constante enquanto a tensão é aumentada. Esta corrente depende linearmente da intensidade da fonte de radiação, um regime útil em alguns contadores de radiação.

C - E: Se a tensão através do tubo de descarga é aumentada para além do ponto $\mathrm{C}$, a corrente irá aumentar exponencialmente. O campo elétrico é suficientemente elevado de modo que, agora, os elétrons inicialmente presentes no gás podem adquirir energia suficiente antes de atingir o anodo para ionizar um átomo neutro. Como o campo elétrico torna-se ainda mais forte, o elétron secundário também pode ionizar outro átomo neutro, levando a uma avalanche de elétrons e à produção de íons. A região de crescimento exponencial é chamada de descarga de Townsend.

D - E: Descargas Corona ocorrem no regime de descargas escuras de Townsend, em regiões do espaço onde o campo elétrico é intenso em gases, como na proximidade de extremidades pontiagudas, arestas ou fios, antes do rompimento dielétrico. Se as correntes coronais são altas o suficiente, descargas corona podem ser tecnicamente 'descargas luminescentes', visíveis a olho nu. Para correntes baixas, toda a corona é escura, conforme esperado para as descargas escuras. Fenômenos relacionados incluem a descarga elétrica silenciosa, uma forma inaudível da descarga filamentar, e a descarga escova, uma descarga luminosa em um campo elétrico não uniforme onde muitas descargas corona estão ativas ao mesmo tempo o que forma flâmulas através do gás.

E: O rompimento dielétrico ocorre no regime de Townsend com a adição de elétrons secundários emitidos a partir do catodo devido ao impacto de íons ou de fótons. No colapso, ou provocando potencial VB, a corrente pode aumentar por um fator de 104 a 108, e é normalmente limitada apenas pela resistência interna da fonte de alimentação ligada entre as placas. Se a resistência interna da fonte de alimentação é muito elevada, o tubo de descarga pode não fornecer corrente 
suficiente para o rompimento dielétrico do gás, e o tubo vai permanecer no regime de descarga corona com pequenos pontos de corona ou descargas de escova próximos dos eletrodos. Se a resistência interna da fonte de alimentação é relativamente baixa, então o gás irá romper o dielétrico na tensão VB, e mover-se em regime normal de descarga luminescente. A tensão de ruptura para um gás e um material de eletrodo em particular depende do produto da pressão e da distância entre os eletrodos, $\mathrm{P} x \mathrm{~d}$, tal como expressa na lei de Paschen (1889).

Descarga luminescente (modo de brilho normal)

O regime de descarga luminescente deve o seu nome ao facto de o plasma ser luminoso. O gás brilha porque a energia dos elétrons e sua densidade são altas o suficiente para gerar luz visível por colisões de excitação. As aplicações de descarga luminescente incluem lâmpadas fluorescentes, reatores de plasma de corrente alternada e placas paralelas, o 'magnetron' de descargas utilizado para depositar filmes finos, e fontes de plasma de eletrobombardeamento.

F - G: Após uma transição descontínua de $E$ a $F$, o gás entra na região de brilho normal, em que a tensão é quase independente da corrente ao longo de várias ordens de grandeza na corrente de descarga. A densidade de corrente do eletrodo é independente da corrente total neste regime. Isto significa que o plasma está em contato com apenas uma pequena parte da superfície do catodo com correntes baixas. Como a corrente é aumentada a partir de F e G, a fração do catodo ocupado pelo plasma aumenta, até que o plasma cobre a superfície inteira do catodo no ponto $G$.

G - H: no regime anormal, acima do ponto $G$, a tensão aumenta significativamente com o aumento da corrente total, a fim de forçar a densidade de corrente catódica acima do seu valor natural e fornece a corrente desejada. Começando no ponto $G$ e movendo-se para a esquerda, uma forma de histerese é observada na tensão-corrente característica. A descarga mantém-se em correntes e densidades de corrente consideravelmente mais baixas do que no ponto $\mathrm{F}$ e só então faz uma transição de volta ao regime Townsend.

Arcos de descargas (modo de arco)

$\mathbf{H}-\mathbf{K}$ : No ponto $\mathrm{H}$, os eletrodos se tornar suficientemente quentes a 
um ponto que o cátodo emite elétrons termionicamente. Se a fonte de alimentação DC tem uma resistência interna suficientemente baixa, a descarga será submetida a uma transição luminescência-arco, H-I. O regime de arco, a partir de I até $\mathrm{K}$ é tal que a tensão de descarga diminui à medida que a corrente aumenta, até grandes correntes são alcançadas ao ponto $\mathrm{J}$, e depois a tensão aumenta lentamente com o aumento da corrente." (ELETRIC GLOW DISCHARGE, 2015, grifo do autor).

\section{Perfil luminescente em um tubo de descargas}

Em um tubo de Crookes é de se esperar enxergar um perfil luminescente como o mostrado na figura 13, com regiões de luminescência e regiões escuras, chamado descargas brilhantes. Essas regiões povoam o tubo à medida que a pressão do gás no seu interior diminui, após o plasma ter sido formado.

Um perfil típico da distribuição espacial dessas regiões de brilho e de escuro no interior de um tubo de Crookes pode ser visto na figura 13. Sua formação e características são brevemente descritas por SALSAC e NELIS (2006, grifo do autor, tradução nossa):

\section{"Introdução a Descargas Brilhantes}

A descarga brilhante possui este nome graças ao brilho luminoso do plasma que ela produz. Quando um campo elétrico suficientemente intenso está presente em um meio gasoso, átomos e moléculas do meio irão romper-se eletronicamente, permitindo que uma corrente elétrica flua. (...)

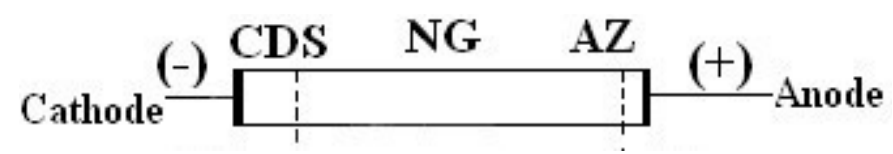

Figura 11: Regiões do tubo de Crookes. Fonte: SALSAC e NELIS (2006).

A configuração mais simples (de um aparato experimental) para se obter uma descarga brilhante consiste de dois eletrodos de placas paralelas (posicionados um em frente ao outro) submetidos a uma diferença de potencial elétrico. Um eletrodo é chamado catodo e é carregado negativamente, o outro eletrodo é o anodo e tem potencial positivo. Uma vez que a descarga brilhante é estabelecida o potencial 
(elétrico) cai rapidamente próximo ao catodo, varia lentamente no plasma e muda novamente nas proximidades do anodo. Consequentemente, o campo elétrico é intenso nas vizinhanças do catodo (Espaço Escuro do Catodo, CDS) e do anodo (Zona do Anodo, AZ). O plasma, ou mais precisamente o brilho negativo (NG), é virtualmente livre de campo elétrico. Os campos elétricos no sistema ficam restritos às bainhas (como são chamadas as regiões) nas adjacências dos eletrodos. Os campos das bainhas repelem os elétrons, que tem uma mobilidade muito maior que os íons, que tentam chegar a cada um dos eletrodos. De fato, o potencial do plasma é sempre maior que o das paredes adjacentes, o que reduz a taxa de perda de elétrons para as paredes. Elétrons originários do catodo serão acelerados, colidirão, ionizarão, transferirão energia e finalmente 'desaparecerão' ao recombinarem com um partícula carregada positivamente. Alguns atingirão o anodo e serão conduzidos ao circuito externo.

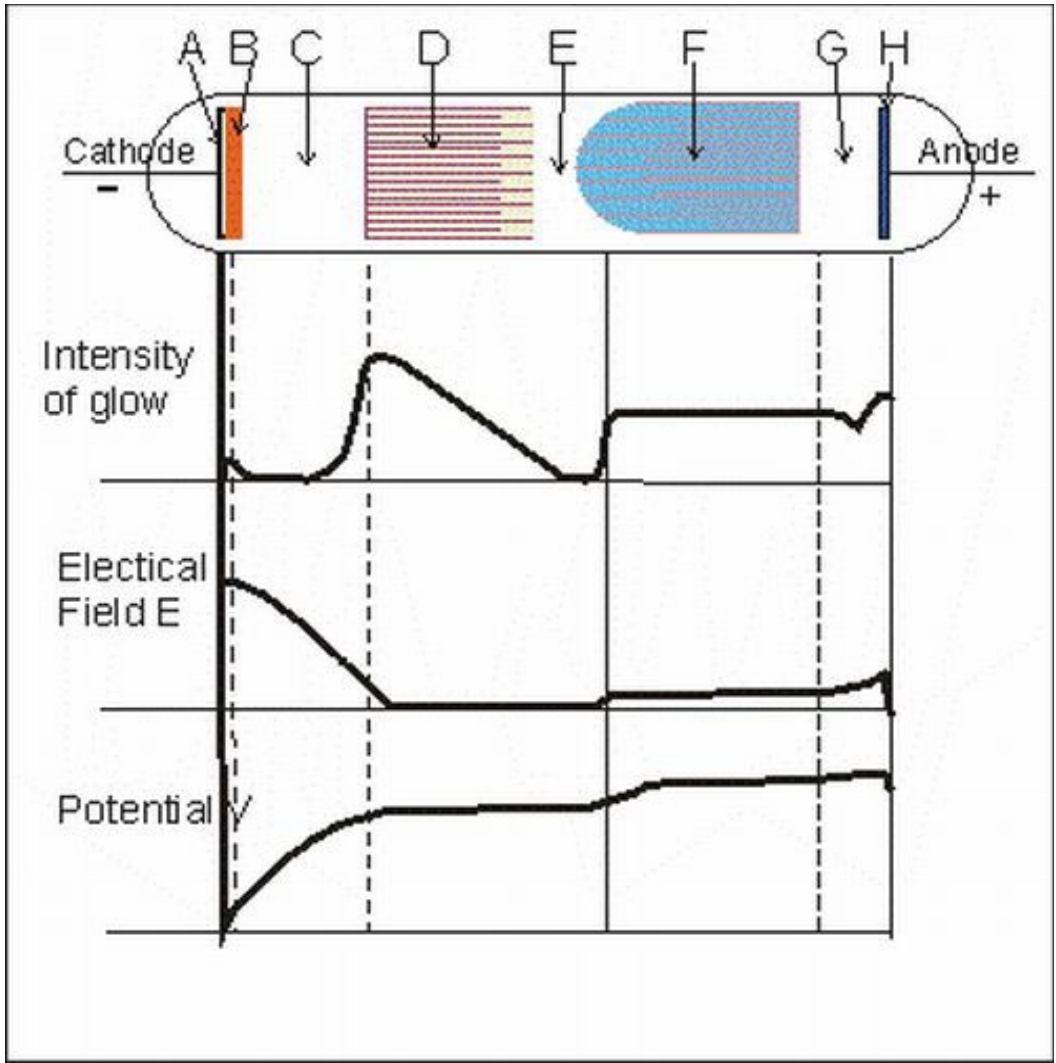

Figura 13: Detalhamento das regiões de luminescencia, da intensidade do brilho, do campo e do potencial elétrico entre os eletrodos. Fonte: SALSAC e NELIS (2006).

O brilho luminescente é produzido porque os elétrons tem energia (adequadamente) suficiente para gerar luz visível por excitação após 
colisões com o gás formador do plasma. Uma vez que há uma contínua perda de elétrons e íons, a ionização deve ser mantida a uma taxa da mesma ordem dessa perda, para que se mantenha estável a produção do brilho luminoso. A energia é continuamente transferida para fora da descarga e aqui o equilíbrio energético também deve ser satisfeito. De modo simplista, os elétrons absorvem energia do campo (elétrico aplicado) pela sua aceleração, ionizam alguns átomos, e o processo se torna contínuo. Elétrons adicionais devem ser produzidos por emissão secundária de elétrons pelo catodo. Estes são muito importantes para suster a descarga. Três grandes regiões majoritárias podem ser identificadas na descarga: a região do catodo, as regiões de brilho e a região do anodo. O espaço escuro de Aston (região $A$ ) é uma região fina próxima ao catodo. O campo elétrico é forte nesta região acelerando os elétrons para longe do catodo. Esta região tem uma carga espacial negativa, o que significa que nela o número de elétrons supera o número de íons. A densidade e a energia dos elétrons no espaço escuro de Aston é muito baixa para excitar o gás de modo eficiente consequentemente a região mostra-se escura.

No Brilho Catódico (região B), região próxima ao espaço escuro de Aston, os elétrons são energéticos o suficiente para excitar os átomos neutros durante as colisões. Na região de brilho catódico a densidade de íons é relativamente alta. O brilho catódico muitas vezes mascara o espaço escuro de Aston uma vez que ele está muito próximo ao catodo. O comprimento axial do brilho catódico depende do gás formador, da pressão e da temperatura.

O espaço escuro do catodo (ou de Crookes, ou de Hitorf) (CDS) (região C) é uma região relativamente escura com um campo elétrico intenso, uma carga espacial positiva e uma densidade de íons relativamente alta. Sua extensão axial depende da pressão e da diferença de potencial (aplicada aos eletrodos). Para descargas operando a poucos Pascal de pressão seu comprimento é de aproximadamente $0.5 \mathrm{~mm}$ (meio milímetro). Nesta região os elétrons são acelerados pelo campo elétrico. ĺons positivos são acelerados em direcão ao catodo. Eles provocam o bombardeio do material do catodo e a emissão de elétrons secundários. Estes elétrons serão acelerados e 
causarão a criação de novos íons pela colisão com átomos neutros. A maior parte da diferença de potencial entre os dois eletrodos acontece através de uma estreita região circundando o catodo, portanto o CDS é também chamado de 'queda do catodo'.

O Brilho Negativo (BN) (região D) é a região de intensidade mais clara em toda descarga. Ela tipicamente se extende por aproximadamente 2-3mm além da amostra (eletrodo). Os elétrons são responsáveis por praticamente toda a corrente na região de brilho negativo. Elétrons que foram acelerados na região do catodo a altas velocidades produzem ionização e elétrons mais lentos que sofreram colisões inelásticas ainda produzem excitações. O brilho negativo é predominantemente gerado por elétrons lentos, entretanto outros processo também tem presença significativa. $\mathrm{A} B N$ é a região onde ocorrem as colisões com maiores níveis para o processo de excitação e ionização por conta da alta densidade de partículas carregadas, tanto positiva quanto negativamente, nesta região. Por isso essa região é a fonte luminosa utilizada nos GDOES (Espectroscopia de Emissão Óptica de Descarga Luminescente (GDOES) prevê uma rápida análise da composição atômica de sólidos tanto condutores como nãocondutores(GLOW, 2009)) e permite que sejam coletadas a maior parte das informações analíticas. Na presença de íons de argônio os elétrons podem determinar a carga espacial. $\mathrm{Na}$ verdade, nesta região as cargas espaciais negativas e positivas são identicas resultando uma carga neutra. Entretanto a corrente elétrica no BN é predominantemente formada por elétrons graças a sua alta mobilidade. Ao final do brilho negativo os elétrons perderam grande parte de sua energia e então os processos de excitação e ionização deixam de ser notados, este é o início da região escura.

A região escura de Faraday (região E) separa o brilho negativo da coluna positiva. A energia dos elétrons é baixa nesta região. A carga elétrica espacial líquida e o campo eletrico axial são baixos.

A coluna positiva (região $F$ ) é um região luminosa que se prolonga desde o brilho negativo até o anodo. Ela tem uma densidade de carga líquida baixa, apenas um baixo campo elétrico típico em torno de $1 \mathrm{~V} / \mathrm{cm}$. O campo elétrico é apenas intenso o suficiente para permitir que 
nível de ionização alcance o anodo. A medida que o comprimento do tubo de descargas aumenta a uma pressão constante as estruturas do catodo não alteram seu tamanho, é então a coluna positiva que se estende para formar uma longa e uniforme região de brilho. A uniformidade do brilho pode facilmente ser perturbada e até deixar de existir quando estrias estáticas ou dinâmicas são observadas.

O brilho anódico (região $G$ ) é ligeiramente mais clara que a coluna positiva e não é sempre que ela é observada. O brilho anódico ou brilho do anodo é a região de fronteira da bainha do anodo.

$\mathrm{O}$ espaço escuro do anodo (região $\mathrm{H}$ ) ou bainha do anodo é a região no espaço entre o brilho do anodo e o próprio anodo. Nela a densidade liquida de carga espacial é negativa pois os elétrons estão seguindo em direção ao anodo. O campo elétrico é maior que na coluna positiva."

\section{Material instrucional}

Para uma compreensão básica dos fenômenos visíveis em um tubo de descargas há uma necessidade natural de se avançar conceitualmente em relação aos tópicos descritos no website.

Esse acréscimo de conteúdo faz parte do que seria um material instrucional dirigido aos professores de ensino médio que inicialmente é apresentado neste texto, nos

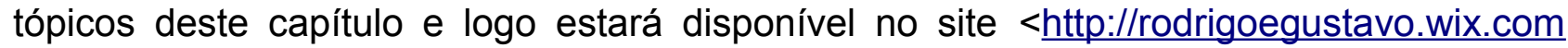
/fisicadeplasmas $>$. 


\section{O projeto}

O projeto de desenvolvimento do equipamento consistiu em planejamento, esboço, desenho técnico, aquisição e produção de peças, montagem e testes de bancada. Abaixo um registro fotográfico usado para documentação do esboço inicial.A intenção é que o aparato possa ser levado a qualquer escola com rede elétrica e comparável ao Tubo de Crookes, pelo modo de geração do plasma, mas que na verdade permite um exploração experimental mais ampla, pois conta com duas flanges de alumínio, com cinco janelas cada, uma bomba mecânica de vácuo, medidores de vácuo, fontes de potência e corrente elétricas controladas. Gera plasma em ar rarefeito a partir de dois eletrodos, tipo chapa, circulares posicionados no interior de um tubo de vidro borosilicato isolado do ambiente pelas flanges de alumínio e conectado à bomba de vácuo. As fotos a seguir mostram detalhes desses elementos do aparato experimental.

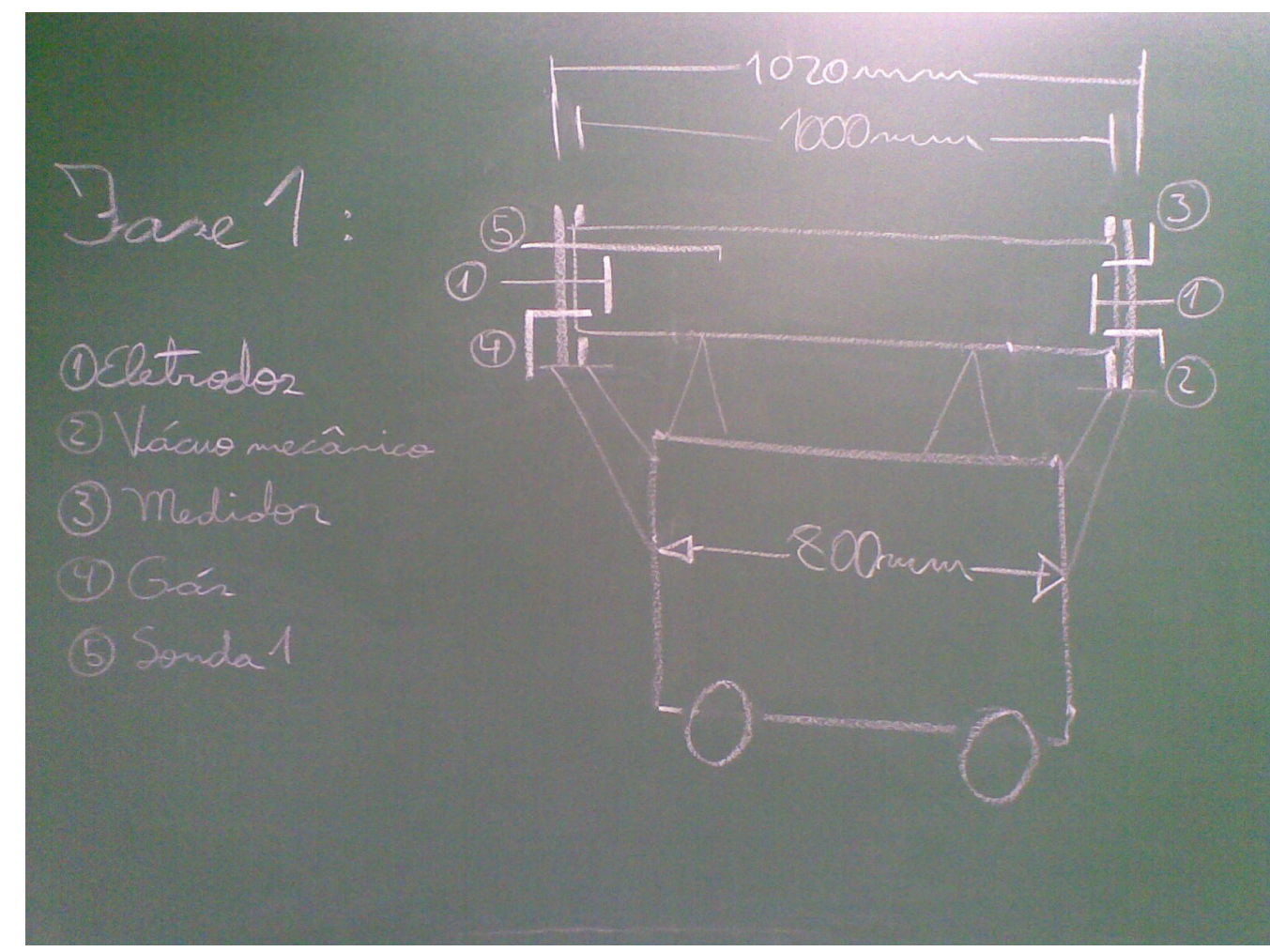

Figura 14: Esboço inicial. Fonte: Projeto do autor.

$\mathrm{Na}$ montagem do aparato utilizou-se equipamentos fora de uso do Laboratório de Plasma do Instituto de Física da UnB bem como peças desenhadas pelo mestrando e manufaturadas pela Oficina Mecânica do Instituto de Física, além de outras adquiridas pelo Laboratório de Plasmas, todos mostrados em fotos e desenhos nas próximas páginas. 


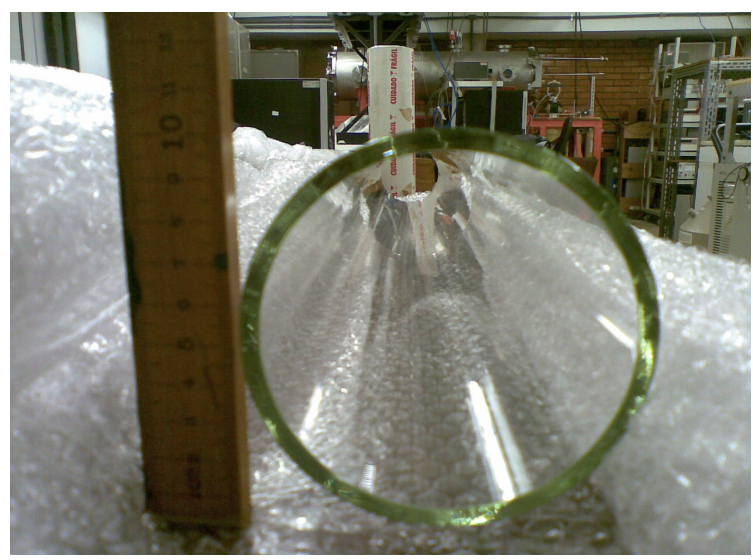

Figura 15: Desembalando o tubo de borosilicado. Fonte: Foto do autor.

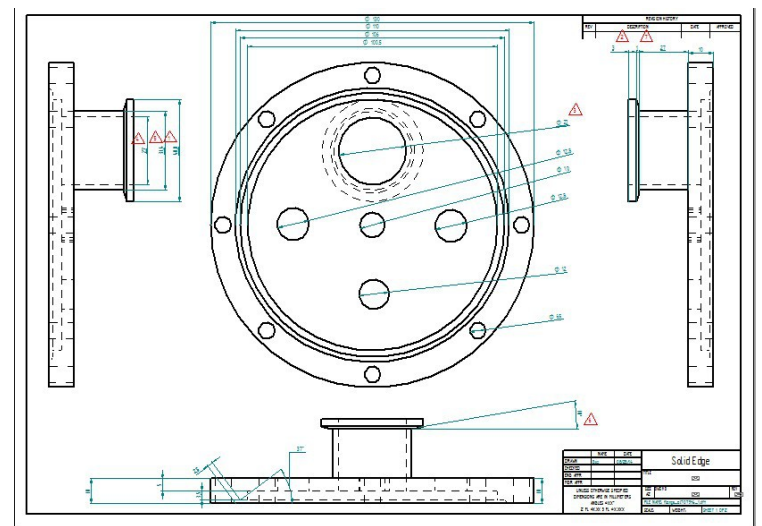

Figura 17: Desenho técnico da flange A. Fonte: Projeto do autor.

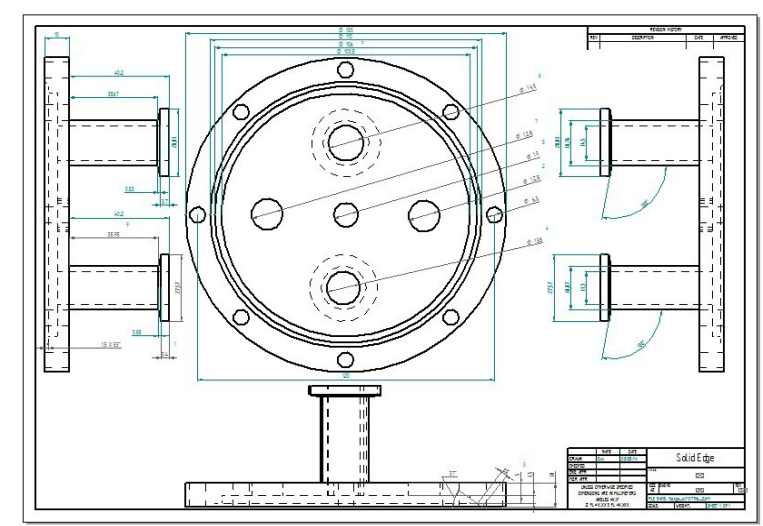

Figura 19: Desenho técnico da flange B. Fonte: Projeto do autor.

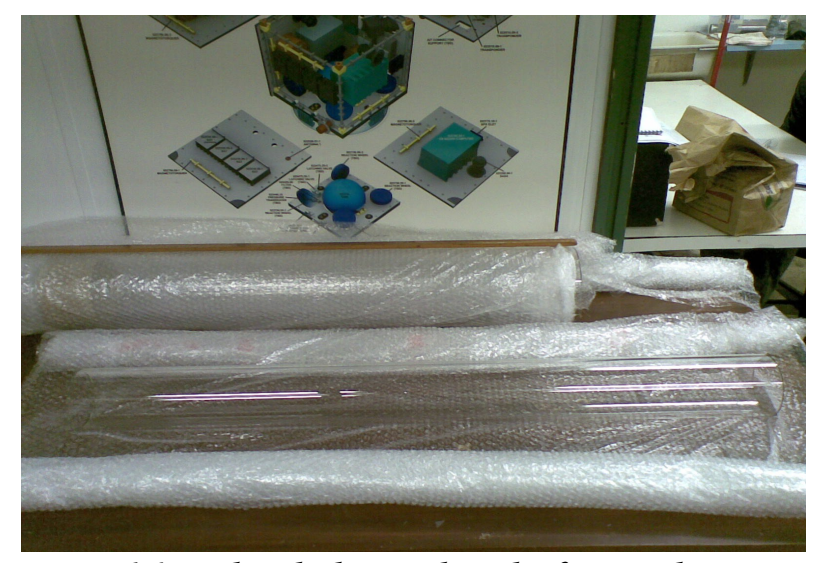

Figura 16: Tubo de borosilicado feito sob encomenda para o projeto. Fonte: Foto do autor.

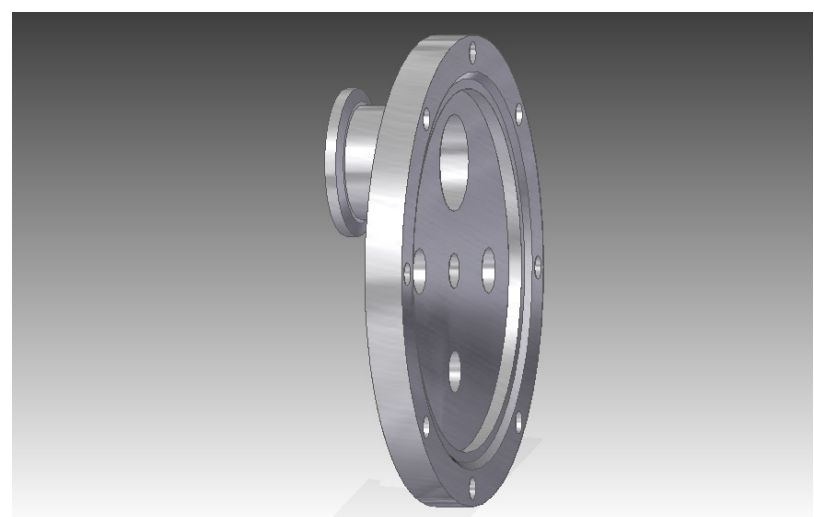

Figura 18: Visão em 3D da flange A com textura de alumínio 7050. Fonte: Projeto do autor.

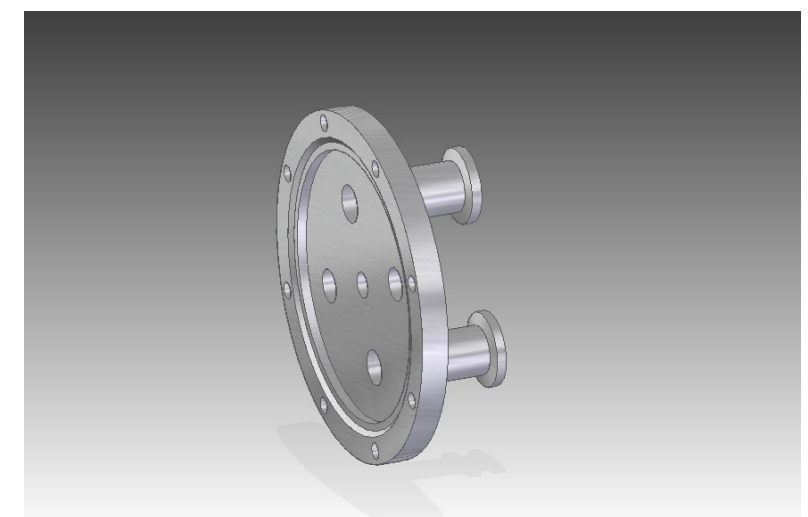

Figura 20: Visão em 3D da flange B com textura de alumínio 7050. Fonte: Projeto do autor. 


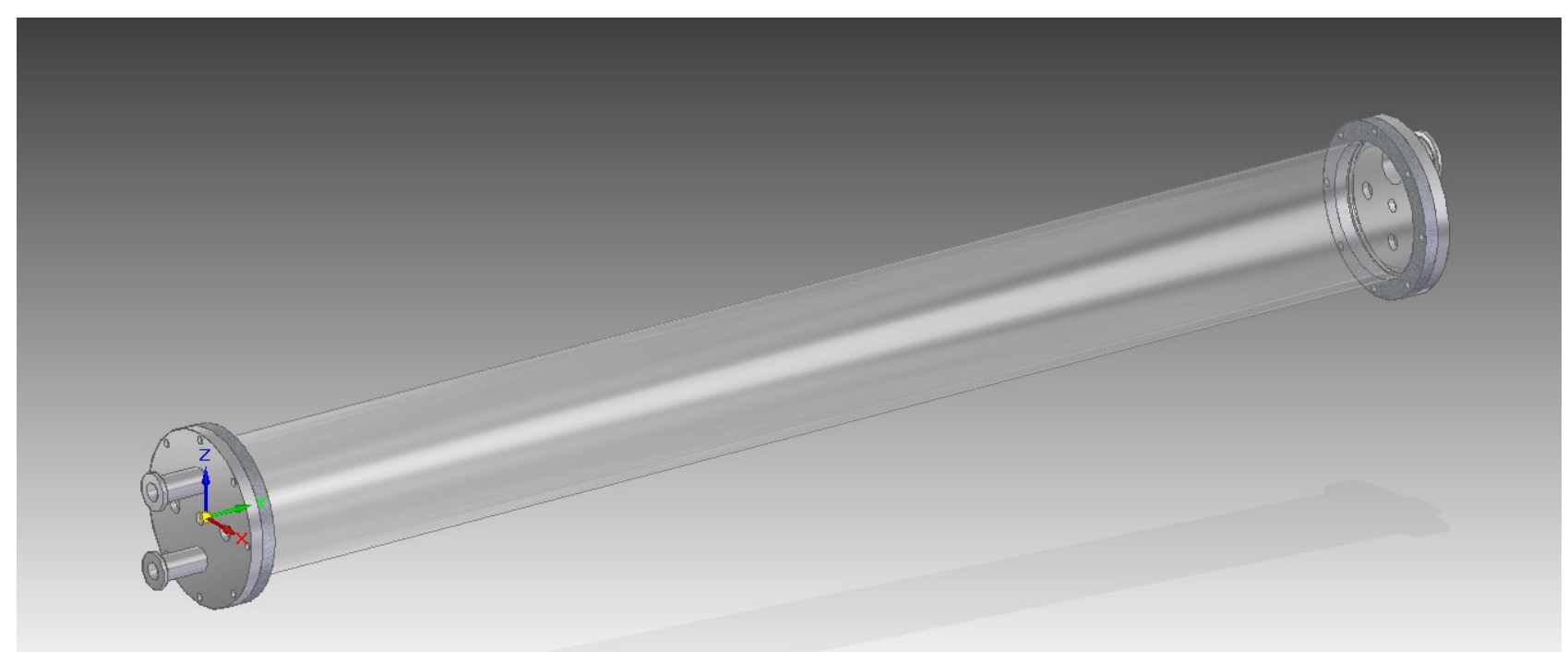

Figura 21: Modelo em 3D projetado do tubo em vidro borosilicato com as flanges e contraflanges encaixadas. Fonte: Projeto do autor.

A montagem preliminar em fase de teste de bancada pode ser vista na foto abaixo.

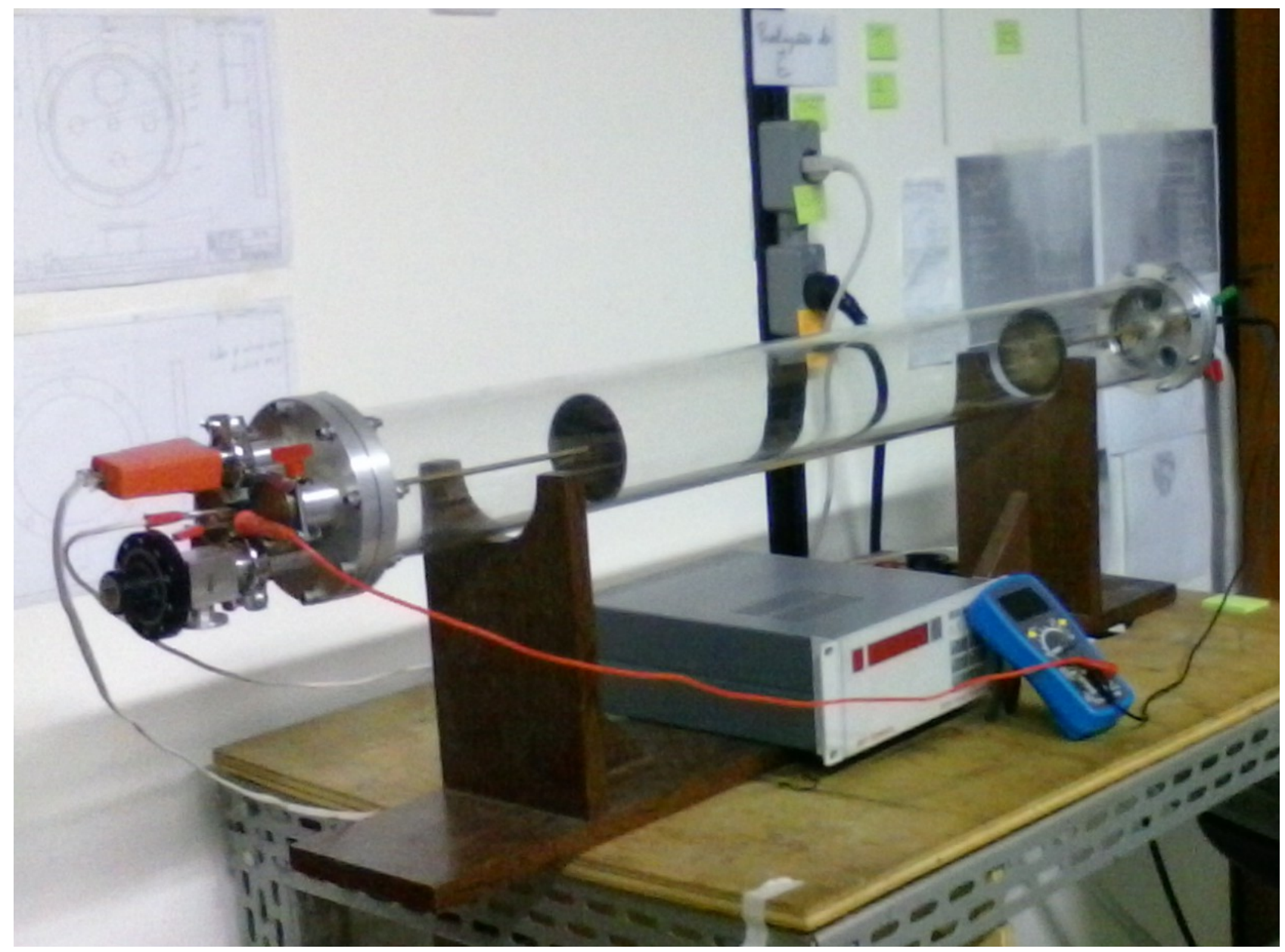

Figura 22: Equipamento montado em teste de bancada. Fonte: Foto do autor. 


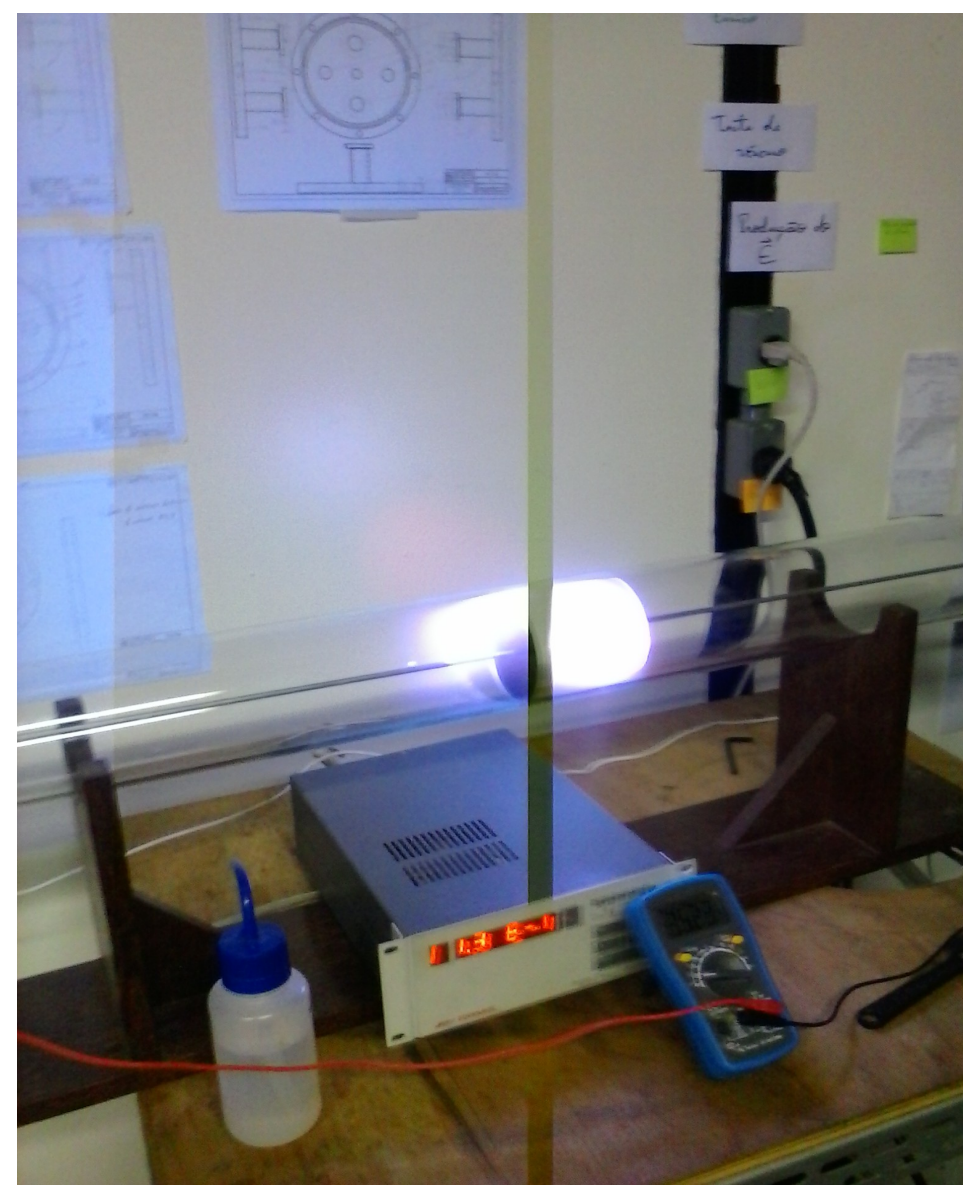

Figura 23: Primeira eletrização do tubo de descargas. Fonte: Foto do autor.

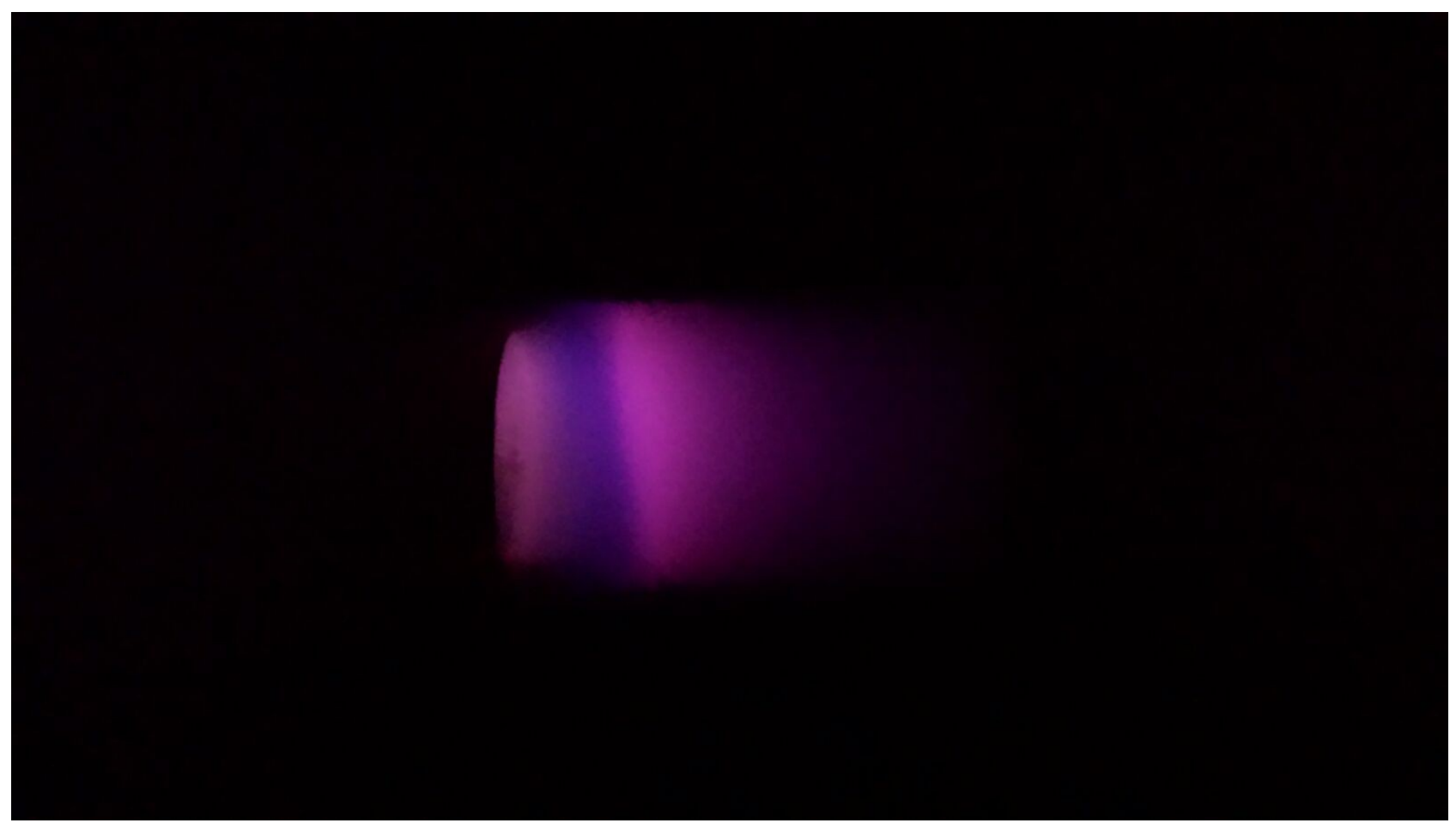

Figura 24: Primeira pluma gerada, plasma no tubo de descargas. Fonte: Foto do autor. 


\section{Método para uso em sala de aula}

O projeto como um todo consiste em três partes distintas: montagem do experimento, elaboração de material instrucional e didático e aplicação em sala de aula.

Visa promover para os alunos uma contextualização histórica dos desafios que as ciências, principalmente a física, enfrentavam nos anos próximos à publicação do artigo de Crookes em 1897. Bem como dos consequentes avanços técnicos, científicos e tecnológicos obtidos nos anos e décadas subsequentes à publicação deste artigo e que proporcionaram a exploração e o uso diversificado do quarto estado da matéria como indicado por HOWATSON (1976). E que quase meio século mais tarde viria a ser definido como plasma por LANGMUIR (1928).

A parte de aplicação em sala de aula é antecedida pela exposição do conteúdo contido na página da internet. Para tanto é sugerido inicialmente ao professor identificar o nível dos alunos fazendo um levantamento dos pré-requisitos que indiquem o nível de maturidade em relação aos conceitos de carga elétrica, força de Coulomb, temperatura, transição de fases, emissão atômica de fótons. E caso haja necessidade de consolidar esses conceitos, o professor pode inverter a ordem das aulas um e dois, iniciando pela abordagem histórica.

Sugere-se que a interação experimental aconteça após as quatro aulas teóricas podendo assim dar condições de uma exploração mais ampla e uma vivência de ensino mais rica.

Infelizmente a aplicação da interação experimental em sala de aula do ensino médio resultou prejudicada em razão de uma dessincronia do calendário das escolas de ensino médio e a finalização da montagem do aparato, boa parte desta dessincronia em razão das inúmeras paralizações ocorridas nos serviços da Universidade de Brasília, ao longo do período 2013 - 2015.

Mesmo assim ainda foi possível apresentar tanto a parte teórica quanto a interação experimental em uma aula para uma turma da disciplina de Introdução à Física de Plasma, ofertada pelo Instituto de Física da Universidade de Brasília e ministrada pelo Professor Dr. José Leonardo Ferreira. 


\section{Capítulo 7 - Conclusão}

Os diversos elementos fornecidos por este trabalho pretendem instrumentalizar ao menos minimamente docentes e discentes para se alcançar resultados significativos de estímulo e aprendizagem na inserção temática da física de plasma nos ensinos fundamental e médio, sem porém afastar a grande possibilidade de futuros aprimoramentos, inclusive servindo de base para o desenvolvimento de novos estudos dentro do próprio programa do MNPEF.

O uso da internet como repositório do conteúdo teórico propicia agilidade em sua atualização, universalização ao acesso e ainda o uso dela como canal de comunicação com estudantes e professores falantes de língua portuguesa em qualquer lugar do mundo.

Verificou-se que a física de plasma tem grande potencial para contribuir com o desenvolvimento de habilidades e competências, tanto das pertinentes aos saberes da Física quanto às pertinetes aos saberes de outros ramos do conhecimento, como a Química e a Astronomia. E ainda, por envolver conteúdos tecnológicos e práticos com aplicações nas mais diversas áreas, está invariavelmente conectada ao cotidiado dos alunos.

A aplicação do produto 1 - site na internet - recebeu avaliação positiva por praticamente todos os alunos. O tubo de Crookes encontra-se em condições de ser levado à sala de aula. Podendo, com sua montagem versátil, ainda receber outros módulos, como campo magnético variável, que possibilitem o seu uso tanto em outros projetos de desenvolvimento de ensino de física quanto em projetos de iniciação científica para o ensino médio, para o ensino técnico e também em nível de graduação e pósgraduação.

O acesso a informações que podem fazer o estudante se não entender melhor, ao menos contextualizar o desenvolvimento científico, tanto os acontecimentos científicos de repercussão midiática atual quanto equipamentos e soluções tecnológicas que os rodeiam, provocou um aumento sensível na disposição deles ao estudo de física e ao 
reconhecimento de sua importância para a formação geral, mesmo para estudantes cujo foco majoritário não está em seguir carreiras de ciências exatas ou engenharias.

No momento ao menos um aluno do MNPEF demonstrou interesse desenvolver seu projeto de mestrado usando o aparato experimental e o site. Recentemente dois alunos de graduação demonstraram interesse em aprofundar seus estudos em física de plasmas a partir de visitas ao laboratório onde o equipamento está sendo montado e, de alguma forma, já contribuem para a sua finalização.

Neste trabalho conseguiu-se afastar a necessidade de pré-requisitos matemáticos, como o uso de equações diferenciais, para compreensão de conceitos modernos como comprimento de Debye e frequencia de plasma, fazendo o uso de analogias e dos conceitos indicados.

Obteve-se desta forma um material conciso e com apelo instrucional capaz de capturar a atenção dos alunos para a relevância do estudo de física e para a presença da física de plasma no dia-a-dia, mostrando-se assim que os conceitos das ciências estão perto deles e que estão em desenvolvimento, procurando aproximar as fronteiras da ciência e à vida cotidiana dos alunos, indicando condições para aprimoramentos conceituais futuros e instigando-os à busca por conhecimento. 


\section{Referências}

ASSIS, A. K. T. Os Fundamentos Experimentais e Históricos da Eletricidade. Montreal: Apeiron, 2010.

ARABATZIS, T. Rethinking the 'Discovery'of the Electron. Studies in History and Philosophy of Science Part B: Studies in History and Philosophy of Modern Physics, v. 27, n. 4, p. 405-435, 1996.

BALL, P. The Elements: A Very Short Introduction. Oxford University Press, 2004.

BOYD, T. J. M.; SANDERSON, J. J. The Physics of Plasmas. Cambridge University Press, 2003.

BRASIL. Constituição da República Federativa do Brasil: promulgada em 5 de outubro de 1988. Contém as emendas constitucionais posteriores. Brasília, DF: Senado, 1988.

BRASIL. Lei 9.394, de 20 de dezembro de 1996, Lei de Diretrizes e Bases da Educação Nacional. Disponível em: <http://www.planalto.gov.br/ccivil_03/Leis/L9394.htm>. Acessado em: 02 jul. 2015.

BRASIL. Lei n 13.005, de 25 de junho de 2014, Plano Nacional de Educação - Década de 2014-2024. Disponível em: <http://www.planalto.gov.br/ccivil 03/ ato20112014/2014/lei//13005.htm>. Acessado em: 02.07.2015.

CHEN, F. F. Introduction to Plasma Physics. New York: Plenum Press, 1974. 329 p.

CROOKES, W. The Bakerian Lecture: On the Illumination of Lines of Molecular Pressure, and the Trajectory of Molecules. Philosophical Transactions of Royal Society of London, 170, p. 135 - 164, London, 1879. Disponível em: $<$ http://rstl.royalsocietypublishing.org/content/170/135.full.pdf+htmll>. Acessado em: 04 ago. 2014.

D'AGOSINO, S. A History of the Ideas of Theoretical Physics. Roma: Ed. Kluwer Academic Publisher, 2000.

D'ANGELO, J. V. H.; ZEMP, R. J. Experimentos em sala de aula para estimular a aprendizagem de conceitos fundamentais em cursos de engenharia. Revista Ensino Superior, Campinas, abril-junho, 2014.

DAHL, P.F. Flash of the cathode rays: a history of the electron of J.J.Thomson. CRC Press, 1997.

DANTON, R. História Geral das Ciências: A ciência no século XX, Parte IV, vol. 12. São Paulo: Difusão Européia do Livro, 1974.

DEBYE, P.; HÜCKEL, E. Zur Theorie der Elektrolyte. Physikalische Zeitschrift, 1923. Disponível em: <http://knowledge.electrochem.org/estir/hist/hist-12-Debye-1.pdf>. Acesso em: 02 mar. 2015. 
ELECTROLYTE Solutions. Organizado por Jahan M. Dawlaty. Department of Chemistry. University of Southern California. Disponivel em: <http://wwwscf.usc.edu/ chem430a/scans/08.pdf> Acesso em: 17 fev. 2015.

ELETRIC GLOW DISCHARGE. Desenvolvido por lan Tresman. Disponível em: $<$ http://www.plasma-universe.com/Electric_glow_discharge>. Sob a licença Creative Commons Attribution 3.0 Unported license. Acessado em: 20.11.2015.

FALCONER. I. Corpuscles, Electrons and cathode rays: J. J. thomson and the 'discovery of the electron'. British Journal for the History of Science, 20, 241-276, 1987.

FITZPATRICK, R. Plasma Physics: An introduction. Boca Raton: CRC Press, 2014. 297p.

FROES, A. L. D. Astronomia, astrofísica e cosmologia para o Ensino Médio. Revista Brasileira do Ensino Física, 2014, vol.36, n.3, pp. 1-15. ISSN 1806-1117.

GAS Discharge Tube: Introduction. Desenvolvido por David W. Knight. Devon: 2013. Disponível em: <http://www.g3ynh.info/disch tube/intro.html>. Acessado em: 20.11.2015.

GASEOUS DIELETRICS: Development of electron avalanche. Curso. Disponível em : <http://nptel.ac.in/courses/108104048/lecture5/slide1.htm>. Acessado em: 20.11.2015.

GASPAR, A.; MONTEIRO, I. C. C. Atividades experimentais de demonstrações em sala de aula: uma análise segundo o referencial da teoria de Vygotsky. Investigações em Ensino de Ciências 10.2, 2005: 227-254.

GEISSLER Biography. The Cathode Ray Tube site: eletronic glassware. Organizado por Henk Dijkstra. Disponível em: <http://www.crtsite.com/Heinrich\%20Geissler.html> Acesso em: 20 jan. 2015.

GLOW Discharge Optical Emission Spectroscopy. Instrutécnica: instrumentação para pesquisa e indústria. Disponível em: <http://www.instrutec.com.br/v2/represen /Spectruma/index.html>. Acessado em: 18.12.2015.

GOEKING, W. Lâmpadas e leds. O Setor Elétrico, São Paulo, ed. 46, nov. 2009. Disponivel em: <http://www.osetoreletrico.com.br/web/a-revista/edicoes/176-lampadas-eleds.html > Acessado em: 20.11.2015.

HEILBRON, J. L. Eletricity in the $17^{\text {th }} \& 18^{\text {th }}$ Centuries: a Study of Early Modern Physics. Berkeley: University of California Press, 1979.

HOWATSON, A. M. Introduction to Gas Discharges. New York: Pergamon Press, 1976. $244 p$.

INAN, U.; GOLKOWSKI, M. Principles of plasma physics for engineers and scientists. New York: Cambridge University Press, 2011.

JAHN, R. G.; CHOUEIRI, E. Y. Electric Propulsion. Encyclopedia of Physical Science and Technology, Third Edition, Volume 5. Princeton University, Academic Press, 2002.

JEAN Antoine Nollet. Versão online da exposição Let's Get Physical: Instruments and the 
Teaching of Physics in the 18th Century. Organização Museum of the History of Science, Oxford. Disponível em: <http://www.mhs.ox.ac.uk/exhibits/get-physical/jean-antoinenollet/> Acesso em: 20 jan. 2015.

JORGE, W. Analogia no ensino da Física. Caderno Brasileiro de Ensino de Física, v. 7, n. 3, p. 196-202, 1990.

LANGMUIR, I. Oscillations in ionized gases. Procedures of the National Academy of Science, Volume 14, 1928.

LIMA, F. M. S.; VENCESLAU, G. M.; BRASIL, G. T. A downward buoyant force experiment. Revista Brasileira de Ensino de Física, v. 36, n. 2, p. 1-5, 2014.

LIMA, F. M. S.; VENCESLAU, G. M.; NUNES, E. R. A new Hooke's law experiment. The Physics Teacher, v. 40, n. 1, p. 35-36, 2002.

MATTHEWS, M. R. HISTÓRIA, FILOSOFIA E ENSINO DE CIÊNCIAS: A TENDÊNCIA ATUAL DE REAPROXIMAÇÃO. Caderno Catarinense de Ensino de Física, v. 12, n. 3: p. 164-214, dez. 1995.

MAXWELL, J. C. A Treatise on Electricity and Magnetism. Oxford: Clareton Press, 1873.

MOREIRA, M. A. Aprendizagem significativa. Brasília: Editora Universidade de Brasília. 1999.

MOREIRA, M. A. Unidades de Ensino Potencialmente Significativas-UEPS. Temas de ensino e formação de professores de ciências. Natal, RN: EDUFRN, p. 45-57, 2012.

NOTICIAS da SBF. LHC identifica provável bóson de Higgs. Editado por Salvador Nogueira. Elaborada pela Assessoria de comunicação da SBF. Disponível em: $<$ http://www.sbfisica.org.br/v1/index.php?option=com_content\&view=article\&id=408>. Acessado em: 18.12.2015.

PCN. Parâmetros Curriculares Nacionais - Ensino Médio, parte III: Ciências da Natureza, Matemática e suas Tecnologias. Trabalho colaborativo de professores e especialistas de todo o país, 2000. Disponível em: <http://portal.mec.gov.br/seb/arquivos/pdf/ciencian.pdf $>$. Acessado em: 10.11.2015.

PCN+ - Ensino Médio. Orientações Educacionais Complementares aos Parâmetros Curriculares Nacionais FíSICA. Trabalho colaborativo de professores e especialistas de todo o país, 2000. Disponível em: <http://www.sbfisica.org.br/arquivos/PCN_FIS.pdf>. Acessado em: 10.11.2015.

SALSAC, L. NELIS, T. Introduction to glow discharges. Glow discharges. First published on the web: 17 October 2006. Disponível em: <http://www.glow-discharge.com/? Physical_background: Glow_Discharges>. Acessado em 18.12.2015.

SANTOS, C. A. Análise. Faculdade de Educação da Universidade de Brasília, em 30.06.2014. Disponível em : <http://www.fe.unb.br/destaques/426-novo-plano-nacional-deeducacao >. Acessado em 02.07.2015.

STUHLINGER, E. Ion propulsion for space flight. New York: McGraw-Hill, 1964. 
TAVARES, M.R.S.; HORA, P.H.A. Proposta e avaliação de alunos e professores sobre inclusão do estudo de plasma no ensino médio. In: SIMPÓSIO BRASILEIRO DE EDUCAÇÃO QUÍMICA, 3., 2009, Salvador. Disponível em: <http://www.abq.org.br/ simpequi/2009/trabalhos/107-5991.htm>. Acessado em: 18.12.2015.

TERRAZZAN, E. A. A inserção da física moderna e contemporânea no ensino de física na escola de ensino médio. Caderno Catarinense de Ensino de Física, v. 9 (3), 209, 1992.

THOMSON, J. J. Cathode Rays. Philosophical Magazine, 44, 293, 1897. Disponível em: $<$ http://web.lemoyne.edu/ giunta/thomson1897.html>. Acessado em: 18.12.2015.

URIAS, G.; ASSIS, A. Experimentos físicos nas salas de aula do ensino fundamental: Meio de acesso à linguagem física. Revista Ciência à Mão, São Paulo, janeiro, 2009.

VENCESLAU, G. M.; FONSECA, A. L. A. Estudo da instabilidade de plasma no espelho magnético via simulação computacional. In: Congresso de Iniciação Científica da UnB, 6., 2000, Brasília. Anais... Brasília: Dupligráfica Editora, 2000. p. 462-462.

WITTENBERG, H. H. Gas Tube Design - Electron Tube Design. RCA Electron Tube Division, Lancaster, 1962, p. $792-817$.

ZARATINI, P. F.; NEVES, M. C. D.; SILVA, S. C. R. Aspectos históricos de Galileu Galiei e suas influências nas práticas de um professor de física. In: ENCONTRO ESTADUAL DE ENSINO DE FÍSICA - RS, 5, 2013, Porto Alegre. Anais... Disponível em: $<$ www.if.ufrgs. br $/ \mathrm{mpef} / 5$ eeefis $/$ sistema/busca_publicacao.php?trabalho $=370>$. Acessado em: 01.12.2014. 


\section{Apêndice A - Resultados do Pré-teste}

Resultados do Pré teste.

\section{3 responses}

Visw al resporeses Publish anaiytics

Summary

1. No contexto da física, você sabe o que é Plasma?

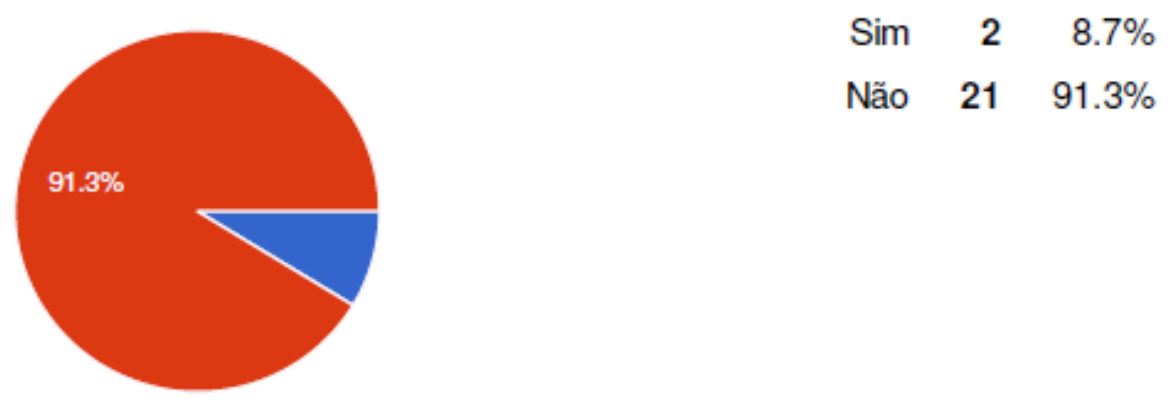

1.1 Se sim, explique:

"Um estado físico da matéria."

"porque de "

"Estado físico entre líquido e sólido um fluído."

2. Você sabe o que há dentro da lâmpada fluorescente?

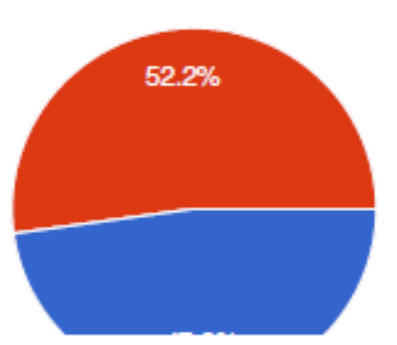

$$
\begin{array}{lll}
\text { Sim } & 11 & 47.8 \% \\
\text { Não } & 12 & 52.2 \%
\end{array}
$$

2.1 E sabe como ela funciona?

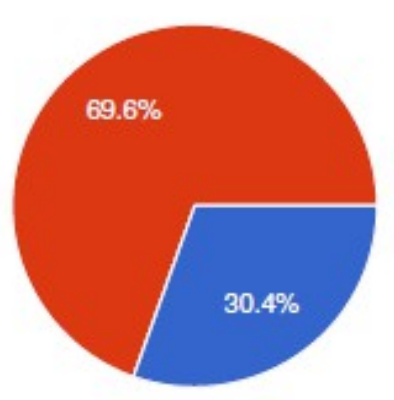

$$
\begin{array}{crr}
\text { Sim. } & 7 & 30.4 \% \\
\text { Não. } & 16 & 69.6 \%
\end{array}
$$


3. Você já ouviu falar de Fusão termonuclear?

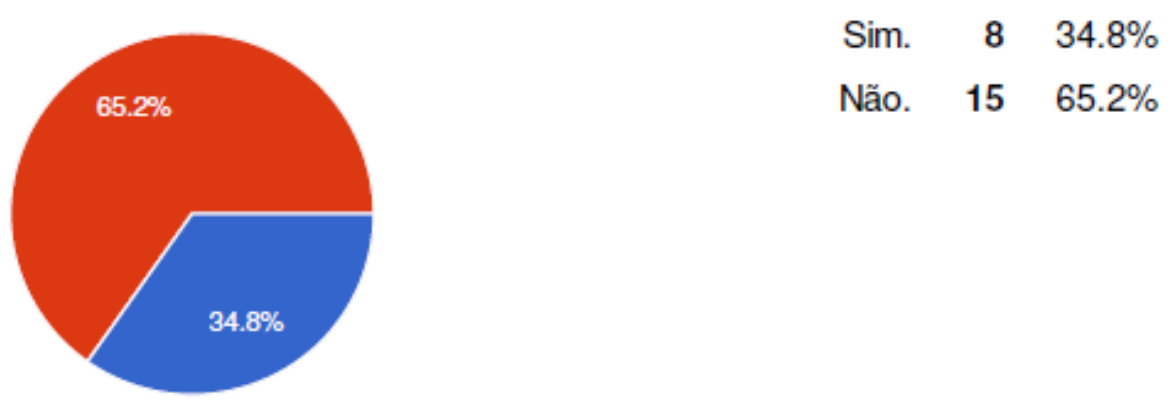

3.1 Se sim, como ela funciona?

"funciona como um reator de temperatura nuclear "

"Só ouvi falar."

"Já ouvi falar, mas não sei explicar."

"Ela funciona como uma forma de energia nuclear."

"porque "

"Fusão de 4 núcleos de hidrogênio para formar um núcleo de helio, sob altas temperaturas."

"Quando ocorre a fusão de um elemtneo nuclear ocorrendo troca de elemento."

4. Você sabe o que é um Tokamak?

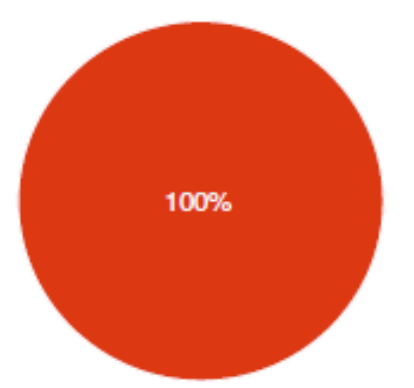

Sim. $00 \%$

Năo. $21 \quad 100 \%$

\section{Você sabe como funciona um tubo de ralos catódlcos?}

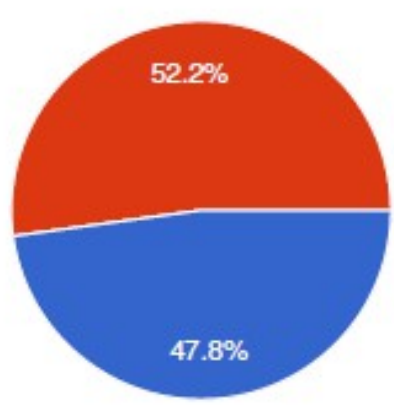

Sim. $11 \quad 47.8 \%$

Năo. $1252.2 \%$ 


\section{Por que é importante estudar eletromagnetismo?}

"Para entender como funciona os equipamentos."

"Porque esse conteúdo cai nas provas importes (sic)."

"Para entender o funcionamento de coisas simples, presentes dentro de sua casa."

"O QUE É ISSO? SE TIVER NO ENEM e VESTIBULARES é importante estudar SIM."

"não sei."

"Para sabermos como os elétrons funcionam."

"Para entendermos como funciona aquilo que não conseguimos observar o funcionamento."

"Para estudar o comportamento do magnetismo."

"Para entender como funciona os fenômenos que o envolve."

"Para compreender efeitos elétricos e magnéticos que são importantes para manter a vida na Terra."

"Para entender como funciona."

"Não sei porque é importante estudar isso."

"Para entender seus fenomenos."

"Porque é importante conhecer como funciona um magnetismo." 


\section{Você gosta de estudar física?}

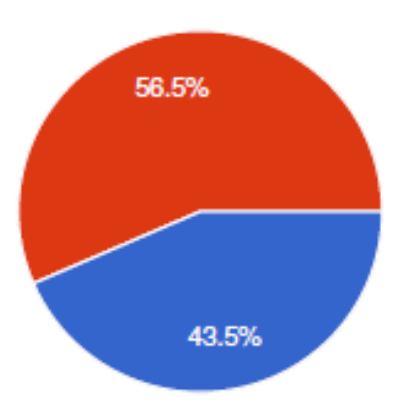

Sim. $\quad 10 \quad 43.5 \%$

Não. $13 \quad 56.5 \%$

\subsection{Por que?}

"Simplesmente não é da minha preferência.

Porque não será útil para meu futuro.

Porém oas formulas é o que mais me complica.

Porque é difícil e contém muita matemática.

Porque eu aprendo mais profundamente sobre como as coisas funcionam.

Não me dou bem com tais matérias de exatas.

Tirar 10 é legal

Pois é interessante entender os fenômenos.

Pois não entendo nada de física.

Porque eu gosto de coisas que tenham números.

Não gosto de exatas.

Porque no futuro o que eu quero trabalhar usa muita física.

PORQUE NÃO ME INTERESSA NÃO SEI NADA E SOU DE HUMANAS.

gosto de exatas

porque é difícil.

Aprender como acontecem as coisas

Porque tem muita fórmula.

Para conhecermos o mundo da gravidade mais a fundo.

pois es??? muito conhecimento.

Tem muita coisa que não consigo entender.

Acho um pouco difícil

Porque envolve matemática, que eu gosto bastante. " 


\section{Você pensa em trabalhar em alguma profissão que utilize o estudo da física diariamente?}

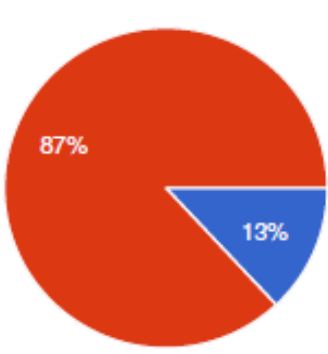

$\begin{array}{rrr}\text { Sim. } & 3 & 13 \% \\ \text { Não. } & 20 & 87 \%\end{array}$

\subsection{Por que?}

"Porque eu não acho que deva ser necessário eu estudar física para a minha profissão.

Porque minha profissão utiliza ciências sociais.

Porque não acho interessante.

Porque jornalismo não precisa de física.

Diariamente não. Quero adm ou ed. física.

Porque eu quero mexer com jogos.

Porque eu sou de humanas.

Porque não quero nada que envolva exatas, querl na parte de humanas.

Não creio que conseguiria.

Pois vou fazer medicina.

Eu não gosto de física.

Porque exatas são legais.

Não tenho facilidade com exatas gosto mais de teorias.

PORQUE NÃO GOSTO E NÃO SEI NADA.

Porque a profissão que escolherei não envolverá física.

Vai ser chato.

porque não é minha vocação.

Porque eu tenho dificuldade em contas.

Nunca. Da muito trabalho.

Porque sou de humanas.

Para produzir equipamentos que facilitem e melhorem a produção industrial." 


\section{0 que você acha deste trabalho aplicado em sua sala de aula?}

"Um bom trabalho para maior aprendizado.

Inesperado e um tanto interessante.

Interessante pois pode fazer com que os professores melhorem sua metodologia e os alunos se interessem mais.

Acho interessante, um acresimo (sic) de informação e conhecimento.

Diferente.

É importante para termos conhecimentos em outras coisas.

Diferenciado

Acho interessante.

LEGAL, EMBORA NÃO SEI NADA, MOSTRA O NÍVEL "FÍSICO" DAS PESSOAS.

Eu não sei não para mim isso é perca (sic) de tempo.

Interessante.

Interessante, por trazer uma visão diferenciada do estudo da física.

Acho importante, sabermos coisa que não sabemos muito.

Interessante e motivador.

Não entendi muito bem ainda, mas é interessante um estudo mais direcionado. Dromos para mim não é um colégio forte e necessita de outros recursos para tentar passar o aprendizado de forma mais didática, Um outro exemplo seria passar as atualidades nos informando todo dia. Importante.

É um trabalho sem sentido real, pois somos preparadas para o vestibular, e somente isso. Não é algo para quem se interessa, mas sim obrigatório. Está se tornando algo muito "padrão".

Bom.

Bom

Importante, pois desse modo" 


\section{Apêndice B - Resultados do Pós-teste}

Resultados do Pós teste

\section{6 respostas}

Visualizar todas as respostas

\section{Resumo}

\section{No contexto da física, você sabe o que é Plasma?}

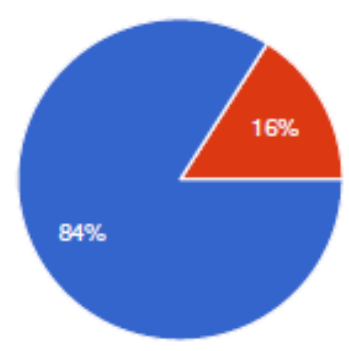

$$
\begin{array}{lrr}
\text { Sim } & 21 & 84 \% \\
\text { Năo } & 4 & 16 \%
\end{array}
$$

\subsection{Se sim, explique:}

"Foi o que o professor falou na aula.

É um estado da matéria que consiste num gás macroscópicamente neutro, porém ionizado.

É um material microscopicamente ionizado.

É uma coleção de átomos neutrons, elétrons livres e ions positivos.

Mais eu não sei explicar.

Uma partícula termonuclear neutra.

É um estado físico da matéria.

É um estado físico da matéria que é encontrado após o estado gasoso e que tem que ser ionizado e macroscopicamente neutro.

Partícula ionizada que respeita uma constante.

É um estado físico.

São partículas ionizadas e macroscopicamente ionizado.

É o $1^{2}$ estado da matéria (ionizado).

É um estado físico da matéria ( $\left(^{2}\right)$ que tem que ser ionizado e macroscopicamente neutro.

A TV de plasma é um exemplo.

É a coleção de átomos neutros, elétrons livres e íons positivos.

Estado físico da matéria.

Estado da matéria que tem maior temperatura que o gás.

É um estado físico da matéria, ioniza e macroscopicamente neutro.

Algo mais quente que o gás.

Particula eletronegativa, macroscopicamente neutra.

É um estado da matéria que consiste num gás macroscópicamente neutro, porém ionizado.

É o estado físico d matéria, tem que ser ionizado." 
2. Você sabe o que há dentro da lâmpada fluorescente?

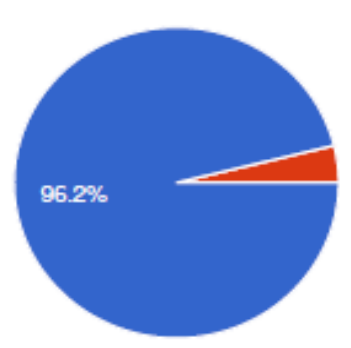

Sim $2596.2 \%$

Não $13.8 \%$

\subsection{E sabe como ela funciona?}

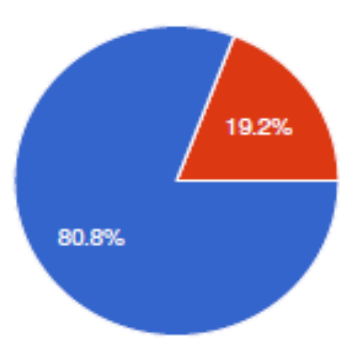

Sim. $21 \quad 80.8 \%$

Não. $519.2 \%$

\section{Você já ouviu falar de Fusão termonuclear?}

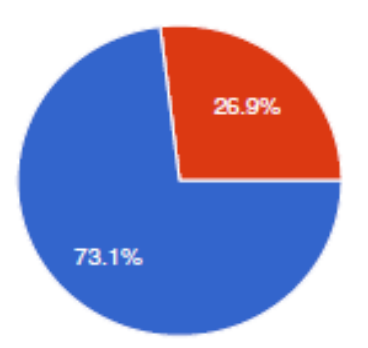

Sim. $1973.1 \%$

Não. $726.9 \%$

\subsection{Se sim, como ela funciona?}

Com ơ"apoio da termodinâmica

São núcleos de prótons que se chocam.

Sim, .... (ilegível).

Como o professor falou na aula.

Fusão de núcleos sobre altas temperaturas.

Através da fusão de atomos.

Fusão de núcleos de núcleos menores para criar um núcleo menos, ocorrendo sob altas temperatura e liberando muita energia.

Núcleo de prótons se chocam.

É a funsão dos núcleos em altas temperaturas.

Funciona atravez de um plasma.

Fusão dos núcleos dos átomos em alta temperatura.

É o choque dos átomos em alta temperatura.

Colidindo dois íons em alta velocidade de modo a fundi-los, liberando energia. 
Năo "sei explicar.

Fusăo de átomos energizados em alta temperatura.

Com a termodinâmica.

Chocam dois prótons em alta velocidade.

Aceleração de partículas.

É o processo no qual dois ou mais núcleos atomicos se juntam e formam outro maior.

4. Você sabe o que é um Tokamak?

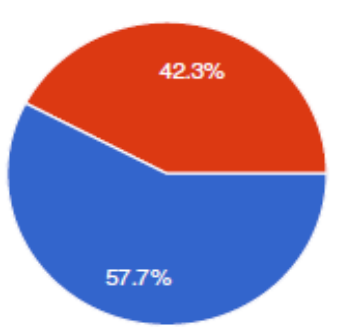

Sim. $15 \quad 57.7 \%$

Năo. $1142.3 \%$

5. Você sabe como funciona um tubo de ralos catódlcos?

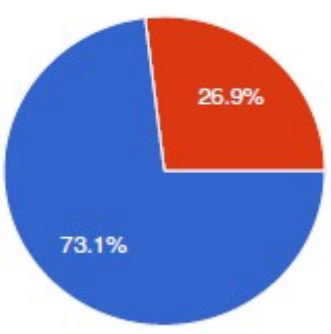

Sim. $19 \quad 73.1 \%$

Năo. $726.9 \%$

\section{Por que é importante estudar eletromagnetismo?}

Para ter conhecimento.

Para compreender a interaçăo de forças magnéticas. 
Para passarmos a ter uma noção de como funcionam as coisas que agem no nosso dia a dia.

Enteder o funcionamento de boa parte de nosso dia-a-dia.

Para geração de energia.

Para compreender fenômenos que ocorrem ao nosso redor.

Porque não é obrigado a entender física.

Pois é um conteúdo que é cobrado em vestibulares.

Pois preciso dele para a proteção da Terra.

Para saber sua importância.

Para compreender a manifestação das forças de interação.

Porque mas e importante.

Reconhecer fenômenos rotineiros.

Para compreender os fenômenos físicos que permitem existir vida na Terra.

Esqueci o que é eletromagnetismo.

Para aprender a estrutura e funcionamento dos átomos.

Para conhecer os elétons que são magnéticos.

Sim, porque o planeta tem um campo magnético que nos mantém aqui.

Para compreender melhor como os elétrons reagem.

Para a obtenção de energia limpa.

Porque é importante saber como funciona.

Porque o nosso planeta e a nossa atmosfera tem um campo eletromagnético, e muito se utiliza dessa força.

Pois é um assunto que utiliza / está presente em varias coisas do nosso dia a dia Porque está no nosso dia-a-dia e cai nas principais provas no Brasil.

Para saber como funciona.

\section{Você gosta de estudar física?}

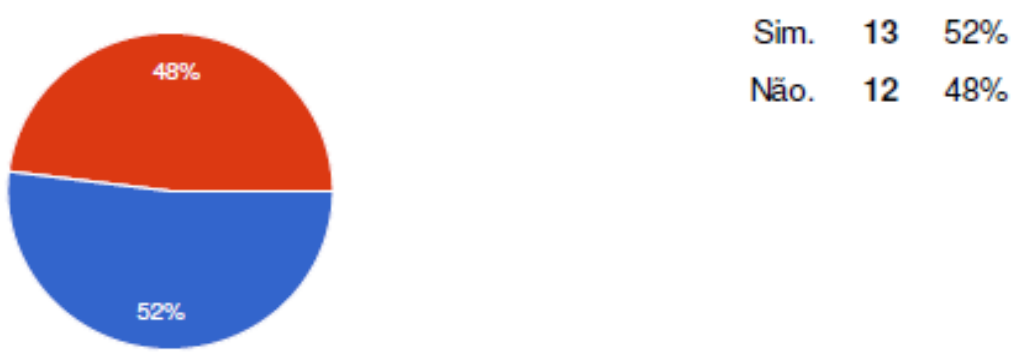

\subsection{Por que?}

Porque no futuro vou precisar.

Prefiro exatas do que humanas.

Não tenho facilidade em exatas.

Porque eu compreendo melhor sobre os elétrons, a energia, etc.

Pois não é uma matéria que me interessa 
Eu rüo tenho jeito para entender física.

Porque não me interesso, eu não gosto de exatas.

Porque não gosto de exatas.

Pois é difícil.

Pois, eu tenho dificuldade em fazer contas.

Porque não me "atrai".

É interessante ver as relações que ocorrem nas matérias.

Porque é interessante entender como os fenômenos ocorrem.

Algumas das matérias são interessantes.

Porque têm matemática envolvida.

Gosto de exatas.

Porque nos permite entender fenômenos sutis do nosso mundo.

Para entender o que acontece no cotidiano.

Não gosto de física.

Pois é interessante saber mais sobe o universo.

Porque não é uma matéria que me simpatizo.

É chato

Porque saber a velocidade do carro ou fogete.

Pois a teoria ajuda a entender várias coisas que vemos no dia-a-dia.

Porque não gosto de estudar.

Não sou de exatas.

8. Você pensa em trabalhar em alguma profissão que utilize o estudo da física diariamente?

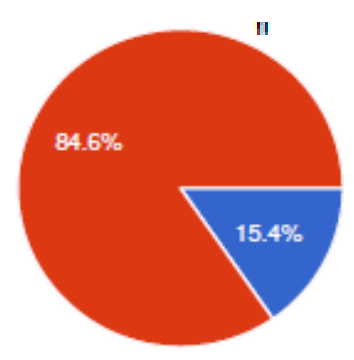

$\begin{array}{rrr}\text { Sim. } & 4 & 15.4 \% \\ \text { Não. } & 22 & 84.6 \%\end{array}$

\section{1 Por que?}

Pois "Ião vejo a física no meu dia-a-dia.

Porque essas interaçôes acabam aparecendo.

Não é minha vocação.

Porque os jogos digitais usam física.

Porqu eeu quero ser outra coisa.

Porque quero fazer direito e no direito não há fíxica diariamente.

Porque quero trabalhar na parte de humanas.

É chato. 
Sou de humanas.

Porque eu ainda não sei em que vou me formar.

Pois prefiro a área de humanas, mas a física é extremamente interessante.

A que eu escolho utiliza humanas

Não todo dia, mas necessito dela em algumas vezes durante a profissão.

Não sou bom em física.

Não gosto de contas.

Porque minha profissão não envolverá física.

Porque não possuo a aptidão, principalmente matemática, que julgo necessária.

Para a construçã de equipamentos que facilitem o trabalho humano.

$\mathrm{Na}$ carreira que quero seguir não utiliza a física

Pois eu tenho dificuldade.

Pois a minha profissão não pede física

Pois a área de trabalho do meu curso não é focado em física.

\section{0 que você acha deste trabalho aplicado em sua sala de aula?}

Lega,"muite interessante e é um assunto novo para nós do ensino médio.

Muito interessante e importante.

Interessante, permite a fuga da dinâmica usual de classe. $\mathrm{O}$ que pode ser benéfico.

Uma excelente forma de aprender mais sobre a física.

Interessante

Importantte para conhecermos o plasma $4^{2}$ estado da matéria.

Bom, pois explica mais sobre a física que nós não temos muito conhecimento.

Interessante, pois mostra a vontade de estimula o interesse no aluno.

Interessante para o entendimento de assuntos até então não abordados em sala de aula, como a física moderna.

Interessante e inesperado.

Interessante.

Bacana e diferente, porém o foco de Bsb tem que estar visado no PAS.

Bom, pois podemos conhecer mais coisas do que já vimos na escola.

Interessante, pelo fato de ter aprendido uma coisa que não sabíamos e que está muito presente no nosso dia.

Um trabalho legal que o aluno aprende novos conteúdos.

Achei bom mais eu não entendo nada sobre física.

Interessante, pois são assuntos que nunca haveríamos tido contato.

Interessante. Ampliar conhecimentos que não seriam estudos no Ensino Médio.

Bom para a turma.

Legal, inspirador e totalmente interessante.

Muito interessante e enriquecedor.

Foi bastante interessante, é algo que acrescentou muito conhecimento. E é algo que não estudamos em sala de aula.

II 
Intere: l'sante, motivador e enriquecedor.

Bom.

Muito legal, não sabia o que era Plasma agora eu sei.

[ilegível] para tem conhecimento. 